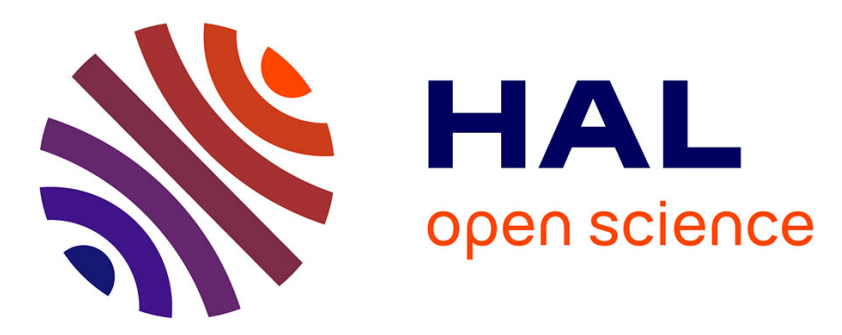

\title{
A new access to dihydrotropones through ring expansion of spirocyclohexadienones: synthesis and mechanism.
}

Marie Varin, Angèle Chiaroni, Jean-Yves Lallemand, Bogdan Iorga, Catherine Guillou

\section{- To cite this version: \\ Marie Varin, Angèle Chiaroni, Jean-Yves Lallemand, Bogdan Iorga, Catherine Guillou. A new access to dihydrotropones through ring expansion of spirocyclohexadienones: synthesis and mechanism.. Journal of Organic Chemistry, 2007, 72 (17), pp.6421-6. 10.1021/jo070594p . hal-00171090}

\author{
HAL Id: hal-00171090 \\ https://hal.science/hal-00171090
}

Submitted on 7 Mar 2021

HAL is a multi-disciplinary open access archive for the deposit and dissemination of scientific research documents, whether they are published or not. The documents may come from teaching and research institutions in France or abroad, or from public or private research centers.
L'archive ouverte pluridisciplinaire HAL, est destinée au dépôt et à la diffusion de documents scientifiques de niveau recherche, publiés ou non, émanant des établissements d'enseignement et de recherche français ou étrangers, des laboratoires publics ou privés. 


\title{
A new access to dihydrotropones through ring
}

\section{expansion of spirocyclohexadienones: Synthesis and}

\author{
mechanism $^{\S}$
}

Marie Varin, Angèle Chiaroni, Jean-Yves Lallemand, Bogdan Iorga, * Catherine Guillou*

Institut de Chimie des Substances Naturelles, CNRS UPR 2301, F-91198 Gif sur Yvette, France

iorga@icsn.cnrs-gif.fr, guillou@icsn.cnrs-gif.fr

Tel. +3316982 30 30; Fax +3316907 7247

RECEIVED DATE (to be automatically inserted after your manuscript is accepted if required according to the journal that you are submitting your paper to)

RUNNING TITLE A new access to dihydrotropones

SYNOPSIS TOC
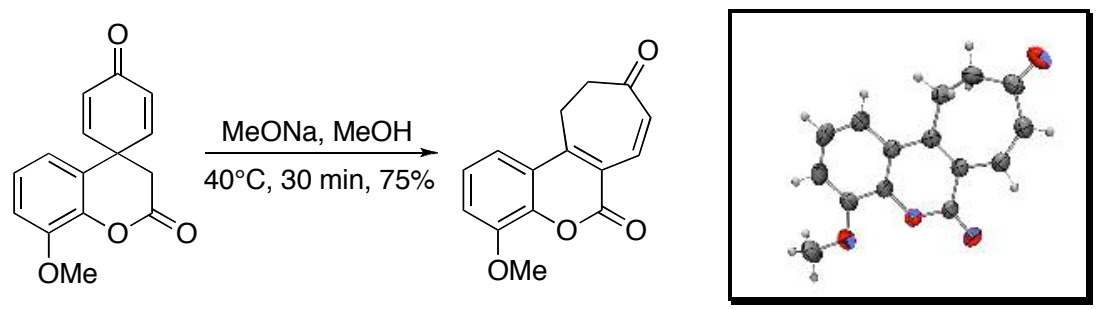

ABSTRACT In this paper we report the rearrangement of spirocyclohexadienones into dihydrotropones in basic conditions as a new method for the preparation of seven-membered ring ketones, which are key building blocks for the synthesis of tropoloalkaloids. DFT calculations and deuterium labeling studies support the mechanism we propose for this rearrangement, involving the ring opening of a spirocyclopropane intermediate followed by successive base-catalyzed 1,3-hydrogen shifts. The X-ray 
structure of the resulting dihydrotropone shows near-perfect planarity and the conjugation gain is likely to be the driving force of the reaction.

KEYWORDS dienone, dihydrotropone, rearrangement, DFT calculations

\section{Introduction}

Substituted carbocyclic seven-membered rings are frequently found in natural and medicinally active compounds (e.g. hinokitiol, ${ }^{1}$ thapsigargins, ${ }^{2}$ colchicine ${ }^{3,4}$ ), and several methods for their synthesis are available, ${ }^{5-7}$ among them, cycloadditions of allyl cations with 1,3 -dienes, ${ }^{8-10}$ metal-catalyzed cycloadditions, ${ }^{11-20}$ electrochemical oxidations, ${ }^{21}$ radical, $^{22-24}$ acidic $^{25,26}$ or thermal ${ }^{27,28}$ ring expansion reactions.

We describe here a new method, the rearrangement of spirocyclohexadienones to one-carbon ring expansion products, dihydrotropones, under basic conditions. ${ }^{29} \mathrm{~A}$ mechanism for this reaction is also proposed, which is fully supported by DFT calculations and deuterium labeling studies.

\section{Results and Discussion}

Reaction conditions. In basic conditions, we observed conversion of the dienone $\mathbf{1}^{30}$ into two products: a one carbon ring expansion product (2a) and a tricyclic ester (3) resulting from the lactone ring opening (Scheme 1). These two compounds are obtained in various ratios according to the reaction conditions.

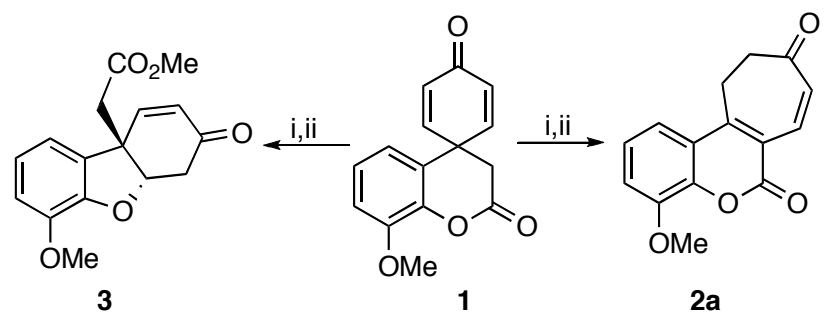

Conditions: i) $\mathrm{MeONa}, \mathrm{MeOH}, 40^{\circ} \mathrm{C}$; ii) $\mathrm{HCl} 1 \mathrm{M}$

Scheme 1. Rearrangement and lactone ring opening products of spirocyclohexadienone 1 in basic conditions. Throughout this study, the following naming system is used: (a) for the keto forms; (b) for the enol forms; (c) for the enolate forms (see Table 1 for more details).

The presence of an efficient protonating agent seems to be essential for the rearrangement of $\mathbf{1}$ into $\mathbf{2 a}$ to occur. Several systems have been investigated at different temperatures $\left(-78^{\circ} \mathrm{C}\right.$ to $\left.75^{\circ} \mathrm{C}\right)$ : i) in the absence of protonating agent $(\mathrm{NaH} / \mathrm{THF})$ no reaction is observed; ii) in the presence of stoichiometric quantity of 
protonating agent (DBU/ $\mathrm{CH}_{2} \mathrm{Cl}_{2}$, potassium phthalimide/THF, lithium $\mathrm{N}$-methyltoluenesulfonamide/THF) we observed the suppression of the lactone ring opening, a slow reaction rearrangement and low yields of 2a $(5-30 \%)$; iii) when the protonating agent is the solvent $(\mathrm{MeONa} / \mathrm{MeOH}, \mathrm{EtONa} / \mathrm{EtOH}, i-\mathrm{PrONa} / i$ $\mathrm{PrOH})$ we observed a fast reaction and the formation of two compounds: the rearrangement product $2 \mathbf{a}$ and the tricyclic ester 3. The best results are obtained with $\mathrm{MeONa}$ in $\mathrm{MeOH}$ at $40{ }^{\circ} \mathrm{C}$ for 30 min, the product 2a being isolated in $75 \%$ yield in these conditions.

During the study of the reaction of 1 with $\mathrm{MeONa}$ in $\mathrm{MeOH}$ at $40{ }^{\circ} \mathrm{C}$ we evidenced two competitive reactions: i) the rearrangement described above, leading to $\mathbf{2 a}$ after protonation and ii) the intermediate formation of the ester $3{ }^{31}$ through the nucleophilic opening of the lactone ring followed by a Michael addition of the resulting phenoxide $\mathbf{8}$ (Scheme 2).

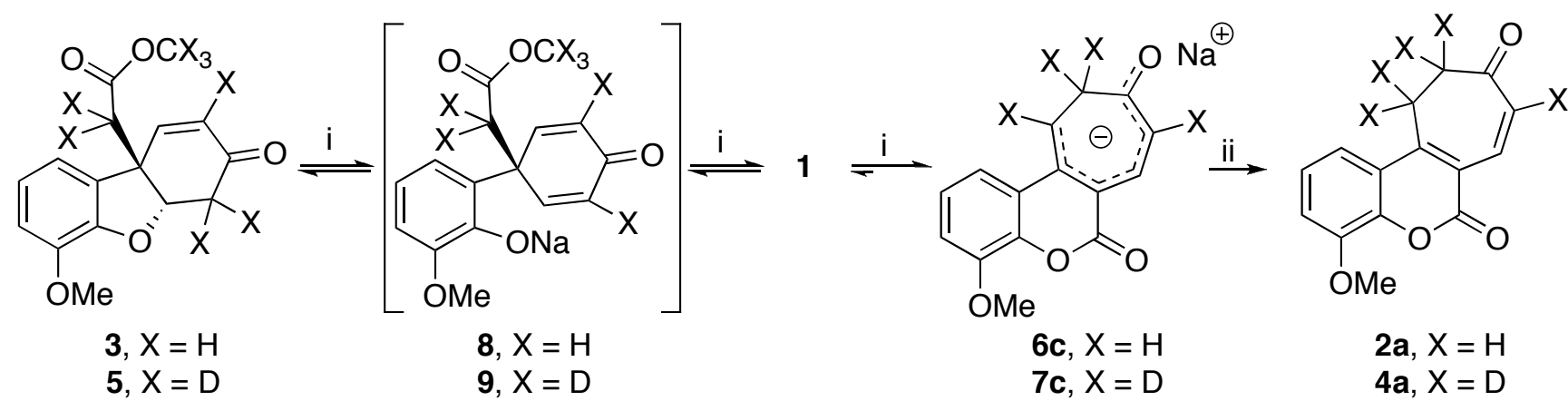

Conditions: i) $\mathrm{CX}_{3} \mathrm{ONa}, \mathrm{CX}_{3} \mathrm{OX}, 40^{\circ} \mathrm{C}$; ii) $\mathrm{HCl} 1 \mathrm{M}$

Scheme 2. Deuterium labeling studies during the rearrangement and lactone ring opening of spirocyclohexadienone $\mathbf{1}$ in basic conditions.

The formation of compound $\mathbf{3}$ proved to be reversible and the equilibrium is shifted towards the thermodynamic product 2a (Figure S1, Supporting information). Figure 1 shows that the ester $\mathbf{3}$ has completely disappeared after $10 \mathrm{~min}$, but the best yields of $\mathbf{2 a}$ are obtained after $30 \mathrm{~min}$ at $40{ }^{\circ} \mathrm{C}$. At lower temperatures $\left(-78^{\circ} \mathrm{C}\right.$ to $\left.20^{\circ} \mathrm{C}\right)$, the ester $\mathbf{3}$ is almost exclusively observed.

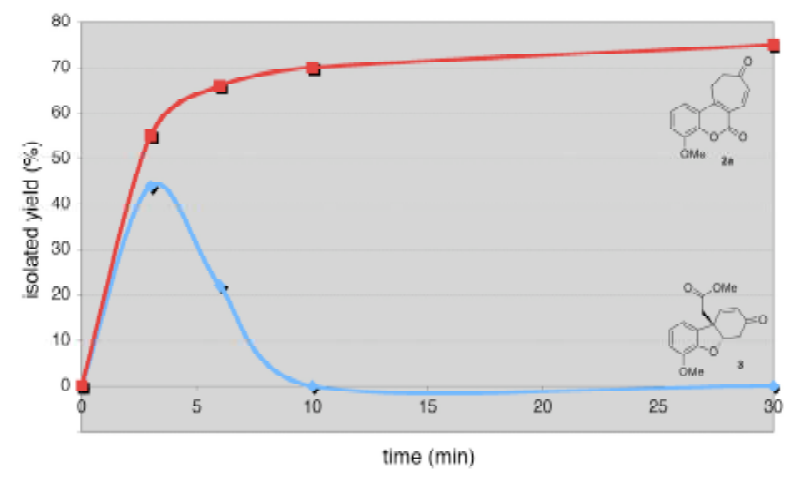


Figure 1. Time-dependent formation of compounds $\mathbf{2 a}$ and $\mathbf{3}\left(\mathrm{MeONa}, \mathrm{MeOH}, 40{ }^{\circ} \mathrm{C}\right)$

When the reaction of 1 with $\mathrm{CD}_{3} \mathrm{ONa}$ in $\mathrm{CD}_{3} \mathrm{OD}$ at $40{ }^{\circ} \mathrm{C}$ is followed by ${ }^{1} \mathrm{H}-\mathrm{NMR}$ (Figure $\mathrm{S} 2$, Supporting information) it is noteworthy that: i) an equilibrium between three species (5, 7c and 9) is immediately established, which is completely shifted towards the delocalized anion 7c after $30 \mathrm{~min}$; ii) the deuterium exchange is very fast and all the enolisable positions are completely deuterated after 3 min. The complete incorporation of deuterium into both positions $\alpha$ to the ketone in $\mathbf{5}$ proves the existence of a dynamic equilibrium between the ester 5 and the open bicyclic phenoxide $9 .{ }^{32}$ Moreover, the reversibility of this process is confirmed by the exclusive formation of the rearrangement product $\mathbf{2} \mathbf{a}$ when the ester $\mathbf{3}$ is treated with $\mathrm{MeONa} / \mathrm{MeOH}$ at $40{ }^{\circ} \mathrm{C}$.

The rearrangement product $\mathbf{2 a}$, in the presence of $\mathrm{CD}_{3} \mathrm{ONa}$ in $\mathrm{CD}_{3} \mathrm{OD}$ at room temperature, is completely deprotonated and immediately forms the enolate $\mathbf{6 c}$, which then undergoes a slow deuterium exchange, complete after $20 \mathrm{~h}$, leading to the enolate 7c (Figure S3, Supporting information).

Reaction mechanism. In the light of the results presented above, we propose the following mechanism for this rearrangement (Scheme 3): the deprotonation of the lactone 1, followed by the intramolecular Michael addition of anion 10 leads to the cyclopropyl derivative 11, which is transformed into the enolate 12c by a cyclopropane ring opening. ${ }^{33}$ The enolate $12 \mathrm{c}$ is then converted into the final protonated product $2 a$.

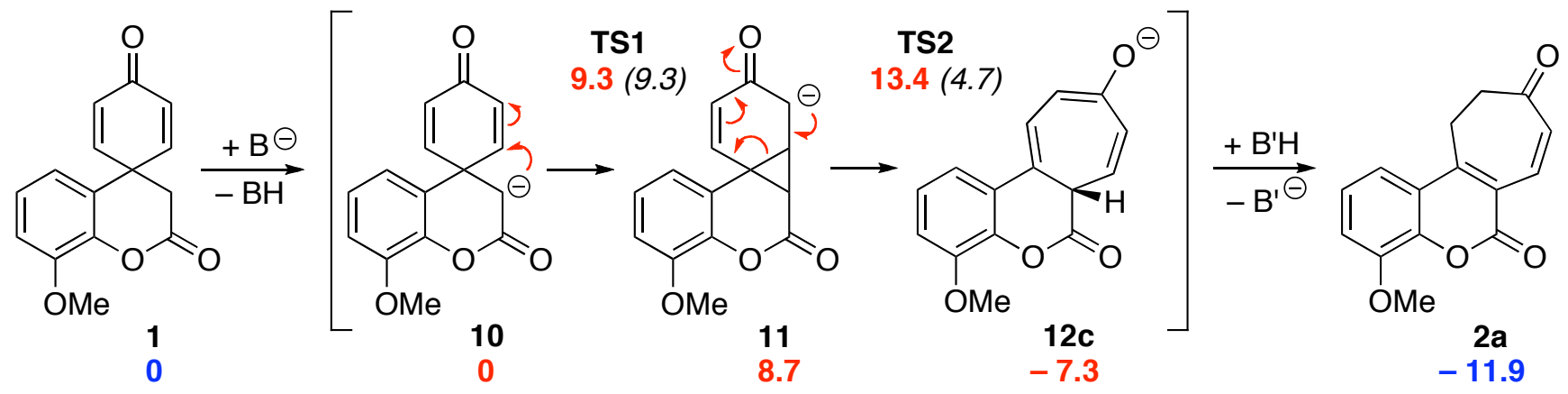
$\mathrm{BH}=\mathrm{MeOH} ; \mathrm{B}^{\prime} \mathrm{H}=\mathrm{HCl}$

Scheme 3. Proposed mechanism for the rearrangement of $\mathbf{1}$ into 2a. Calculated relative energies $(\mathrm{kcal} / \mathrm{mol})$ of neutral compounds are represented in blue and those of anions and transition states (TS) in red. In brackets are reported the activation barriers (kcal/mol).

In order to support the proposed mechanism, the structures of intermediates and transition states were optimized at the B3LYP level with the $6-31++\mathrm{G}(\mathrm{d}, \mathrm{p})$ basis set using Gaussian $03^{34}$ (Scheme 3). Intrinsic 
reaction coordinate (IRC) path calculations are in full agreement with a spirocyclopropane intermediate 11, which rearranges to give a seven-membered ring enolate 12c. The activation barrier energies for TS1 and TS2 (9.3 and $4.7 \mathrm{kcal} / \mathrm{mol}$, respectively) are not very high, which is consistent with the mild reaction conditions used for this transformation. The driving force of the rearrangement is likely to be the greater extent of conjugation in $\mathbf{2} \mathbf{a}$ than in $\mathbf{1}$, confirmed by the near-perfect planarity of the X-ray structure.

Whereas the mechanism for the conversion of $\mathbf{1}$ into $12 \mathrm{c}$ is relatively intuitive, the second part of the mechanism presented in Scheme 3, the conversion of the enolate 12c into the rearrangement product $2 \mathbf{a}$, is not so obvious. We have formulated two hypotheses: a) a sigmatropic hydrogen shift and b) a basecatalyzed 1,3-hydrogen shift.

a) Sigmatropic hydrogen shift. Three pathways can be envisaged for the conversion of $\mathbf{1 2 b}$ into $\mathbf{2 b}$ through a sigmatropic mechanism: i) one direct [1,3] hydrogen shift; ii) three consecutive [1,5] hydrogen shifts; iii) two consecutive $[1,7]$ hydrogen shifts (Scheme 4). These sigmatropic shifts can theoretically take place before or after the protonation step, thus both neutral and anionic forms of the possible intermediates must be considered.
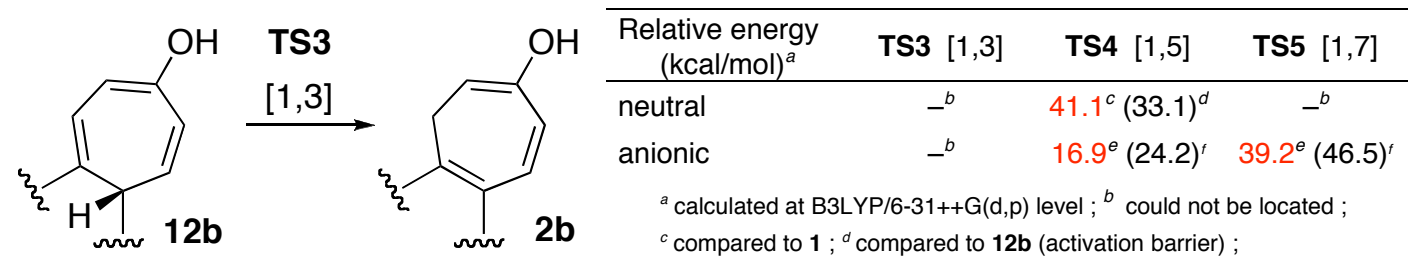

${ }^{c}$ compared to $1 ;{ }^{d}$ compared to $\mathbf{1 2 b}$ (activation barrier)

${ }^{e}$ compared to $10 ;{ }^{f}$ compared to $12 \mathrm{c}$ (activation barrier).
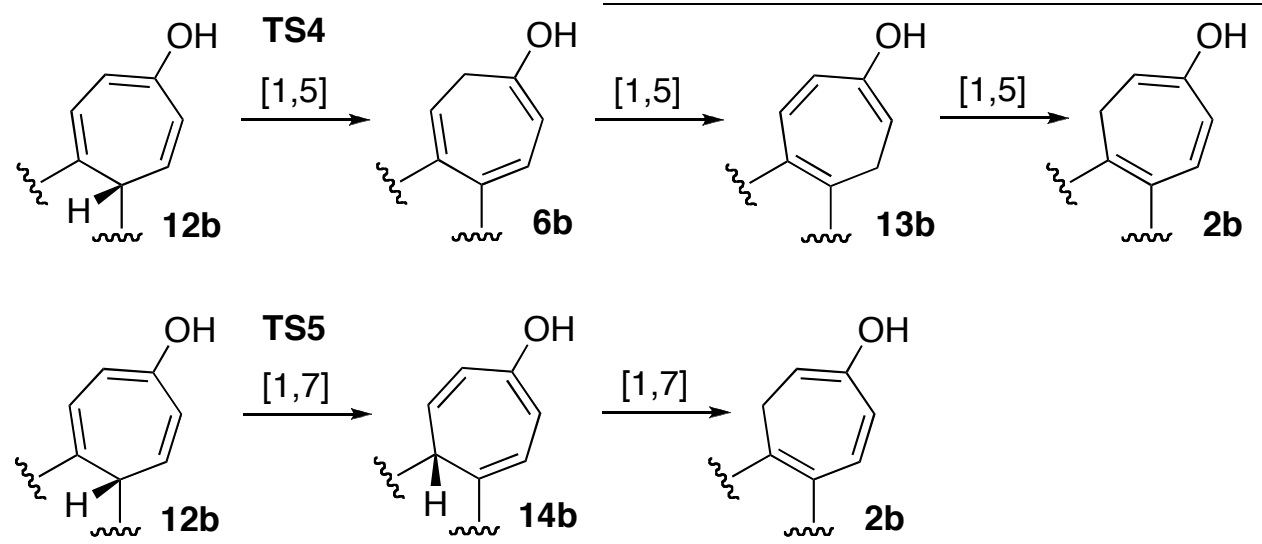

Scheme 4. Three different possible pathways for the conversion of $\mathbf{1 2 b}$ into $\mathbf{2 b}$ through sigmatropic reactions. 
In the cycloheptatrienic systems only the suprafacial hydrogen shifts are possible for steric reasons, thus the $[1,3]$ and $[1,7]$ hydrogen shifts are thermally forbidden, whereas the [1,5] hydrogen shift is allowed. ${ }^{35-39}$ In order to evaluate the conditions required for the sigmatropic shift in this rearrangement, we optimized the structures and calculated the energies for all intermediates, as well as for the transition states in the first sigmatropic shift (Scheme 4, Table 1).

We succeeded in locating valid transition states only in three cases, for neutral TS4n, anionic TS4a and anionic TS5a. ${ }^{40}$ The difference of activation barriers between the neutral and anionic forms of TS4 is almost $9 \mathrm{kcal} / \mathrm{mol}$, so it seems that the sigmatropic rearrangement is more favored in the anionic series. However, in spite of the lower value obtained for TS4a $(24.2 \mathrm{kcal} / \mathrm{mol})$, this activation barrier is still too high to be compatible with the mild conditions used for this reaction. The activation barrier of the anionic form TS5a is higher than that of TS4a, as expected for a forbidden sigmatropic shift.

All these calculations data suggest that there is no sigmatropic shift involved in this mechanism; this is further supported by the complete deuterium exchange observed for the two methylene groups in $4 \mathbf{a}$ (Scheme 2), which is not compatible with a sigmatropic shift.

As suggested by one of the referees, in the light of Herndon's studies, ${ }^{11}$ we investigated the possibility to convert 2a into 13a by two successive thermal [1,5] hydrogen shifts. However, heating 2a in $p$-xylene at $140{ }^{\circ} \mathrm{C}$ for $16 \mathrm{~h}$ led only to the partial conversion of $\mathbf{2 a}$ into $\mathbf{1 3 a}$ and from the mixture of these two compounds (ratio $\mathbf{2 a} / \mathbf{1 3 a}=3 / 1$ ) 13a was isolated in $11 \%$ yield. Longer reaction time (3 days) resulted in extensive decomposition. These results are in agreement with an extended delocalized system in our case, a high activation barrier for the thermal [1,5] hydrogen shifts and support the greater stability (1.6 $\mathrm{kcal} / \mathrm{mol}$ ) calculated for $\mathbf{2 a}$ compared to $\mathbf{1 3 a}$.

Table 1. Calculated relative energies of all possible intermediates in the sigmatropic rearrangement

\begin{tabular}{llll}
\hline \multirow{2}{*}{ Structure } & \multicolumn{3}{c}{ Relative energy $(\mathrm{kcal} / \mathrm{mol})^{a}$} \\
\cline { 2 - 4 } & keto $(\mathbf{a})^{b}$ & enol $(\mathbf{b})^{b}$ & enolate $(\mathbf{c})^{c}$ \\
\hline
\end{tabular}




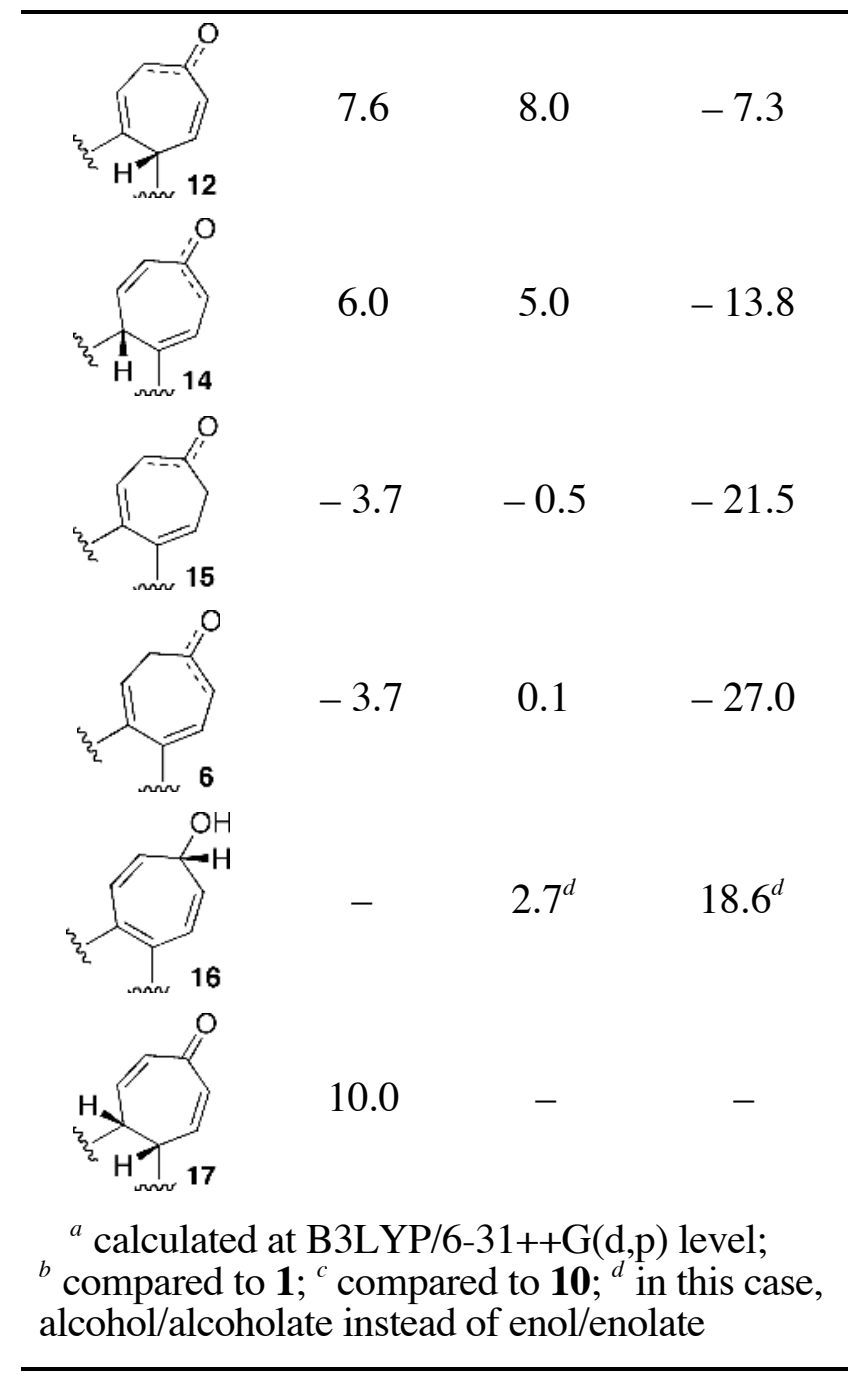

However, from the results of the Table 1, it is noteworthy that, with one exception (structures 14), the keto form is always more stable than the enol, the difference of energies being very important for 2 and 13. This is in agreement with the experimental results ${ }^{41}$ showing that the cycloheptadienone is the major form in this keto-enol equilibrium. Moreover, the energies of compounds 12, 14 and 17, bearing ring junction hydrogen atoms, are unusually high, for both keto and enol forms. This is the consequence of the significant geometrical change induced by the presence of these hydrogen atoms, which prevents the conjugation between the 7-membered ring and the other two rings.

b) Base-catalyzed 1,3-hydrogen shift. Several examples of this type of transformation are described in cycloheptatrienic systems, catalyzed by triethylamine, ${ }^{42-45} 1,8$-diazabicyclo[5.4.0]undec-7-ene ${ }^{27,28}$ or potassium tert-butoxide. ${ }^{46,47}$ The mechanism and regioselectivity have been studied for cycloheptatrienes bearing electron withdrawing groups. ${ }^{48-52}$ There are also a few examples of thermal, ${ }^{53-57}$ photochemical $^{58}$ or acid-catalyzed $^{57,58} 1,3$-hydrogen shifts. In most cases, the hydrogen atom shifts from a ring-junction 
position to the nearest unsubstituted position (path A, Scheme 5). ${ }^{27,28,42-44,56-58}$ In the case where cycloheptatriene 18 has $\mathrm{R}^{1} \neq \mathrm{H}$ (path $\mathrm{B}$, Scheme 5), the 1,3-shift is very unfavored. The system evolves towards the spirodienone $\mathbf{2 1}^{43,53-55}$ if an oxygenated substituent is present at $\mathrm{R}^{2}$ or remains in the less constrained norcaradiene form $\mathbf{2 0}^{59}$ in the other cases. To sum up the above, the pathways and the final products are determined by the stability given by the substituents present on the molecule.

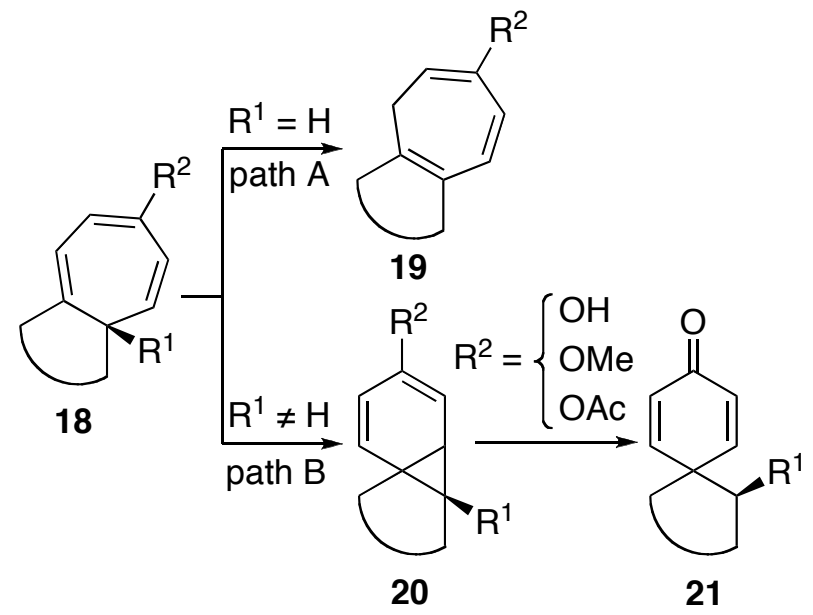

Scheme 5. Influence of the ring substituents in the evolution of cycloheptatrienic systems

In our study, the intermediate $\mathbf{1 2 c}$ is a particular form of $\mathbf{1 8}$, with $\mathrm{R}^{1}=\mathrm{H}$ and $\mathrm{R}^{2}=\mathrm{O}^{-}$. Following the path $\mathrm{A}$, the enolate 12c is protonated and the resulting compound 12a forms the enolate $\mathbf{6 c}$ by deprotonation at the ring-junction position. This deprotonation represents the first step of the basecatalyzed hydrogen shift. In the second step, the delocalized enolate 6c can be protonated at several positions to give either the compounds $12 \mathbf{a}, \mathbf{6 a}$ or $\mathbf{2 a}$, which are in equilibrium via $\mathbf{6 c}$ as a common intermediate (Scheme 6). 
<smiles>[B][Hg]([O-])C=CC12C=CC([O-])=CC=C1c1cccc(OC)c1OC2=O</smiles>

$12 \mathrm{c}$<smiles>COc1cccc2c1OC(=O)C1(C=C[Hg])C=CC(=O)CC=C21</smiles>

$12 a$<smiles>COc1cccc2c1OC(=O)C1C=C(O)C(=O)C=C1C=C2</smiles><smiles>COc1cccc2c3c(c(=O)oc12)=CCC(=O)CC=3</smiles>

$6 a$<smiles>COc1cccc2c3c(c(=O)oc12)C=CC(=O)CC3</smiles>

2a

Scheme 6. Proposed mechanism for the conversion of $12 \mathrm{c}$ to $\mathbf{6 c}$. The red dots represent the positions completely deuterated when the reaction is carried out in $\mathrm{CD}_{3} \mathrm{OD}$

This equilibrium is completely shifted towards the enolate $\mathbf{6 c}$, which is the only species visible in the NMR spectrum. The complete incorporation of deuterium in the positions marked with red dots in Scheme 6 supports the existence of successive base-catalyzed 1,3-hydrogen shifts leading to the enolate $\mathbf{6 c}$, which is the most stable of all anionic intermediates (Table 1). The protonation of $\mathbf{6 c}$ leads exclusively to the isomer $\mathbf{2 a}$, the most stable compound among $\mathbf{2 a}, \mathbf{6 a}$ and 12a (Table 1).

The deuterium labeling results indicate that the mechanism of the rearrangement involves base-catalyzed 1,3-hydrogen shifts. This conclusion is supported by the calculations data.

\section{Conclusion}

In this paper we report the rearrangement of spirocyclohexadienones into dihydrotropones in basic conditions as a new method for the preparation of seven-membered ring ketones, which are key building blocks for the synthesis of tropoloalkaloids. We gained insight into the mechanism that we proposed for this rearrangement by DFT calculations of the possible intermediates and transition states as well as by deuterium labeling. All these data allowed us to choose between two possible paths and thus conclude that the mechanism involves a base-catalyzed 1,3-hydrogen shift in the cycloheptatrienic system obtained from the opening of a fused cyclopropane intermediate.

\section{Experimental Section}


General Remarks. Starting materials and reagents were purchased from a commercial supplier and used without further purification with the exception of $\mathrm{MeOH}$, which was distilled over $\mathrm{Mg}$ and $\mathrm{I}_{2}$.

\section{Synthesis of methyl 2'-(4-methoxy-7-oxo-5a,6,7,9a-tetrahydrodibenzo[b,d]furan-9a-yl)acetate}

(3). To a solution of 8-methoxyspiro[chroman-4,1'-cyclohexa[2',5']diene]-2,4'-dione $\mathbf{1}^{30}$ (20 mg, 0.078 $\mathrm{mmol})$ in methanol $(0.5 \mathrm{~mL})$ was added trifluoroacetic acid $(0.1 \mathrm{~mL}, 1.3 \mathrm{mmol})$. After stirring $16 \mathrm{~h}$ at room temperature, the mixture was concentrated in vacuo. Preparative silica gel TLC (heptane / ethyl acetate 50 / 50) afforded $20 \mathrm{mg}$ of methyl 2'-(4-methoxy-7-oxo-5a,6,7,9a-tetrahydrodibenzo[b,d]furan-9a-yl) acetate 3 as a pale yellow oil $(87 \%):{ }^{1} \mathrm{H}$ NMR $\left(500 \mathrm{MHz} \mathrm{CDCl}_{3}\right) \delta 6.94(\mathrm{dd}, J=7.7,7.8 \mathrm{~Hz}, 1 \mathrm{H}), 6.86(\mathrm{~d}$, $J=7.7 \mathrm{~Hz}, 1 \mathrm{H}), 6.83(\mathrm{~d}, J=7.8 \mathrm{~Hz}, 1 \mathrm{H}), 6.57(\mathrm{dd}, J=10.3,2 \mathrm{~Hz}, 1 \mathrm{H}), 6.02(\mathrm{~d}, J=10.3 \mathrm{~Hz}, 1 \mathrm{H}), 5.13$ (m, 1H), $3.88(\mathrm{~s}, 3 \mathrm{H}), 3.69(\mathrm{~s}, 3 \mathrm{H}), 3.09(\mathrm{~d}, J=14.3 \mathrm{~Hz}, 1 \mathrm{H}), 3.13(\mathrm{dd}, J=17.7,2.8 \mathrm{~Hz}, 1 \mathrm{H}), 6.03$ (dd, $J=17.7,4.2 \mathrm{~Hz}, 1 \mathrm{H}), 2.90(\mathrm{~d}, J=15 \mathrm{~Hz}, 1 \mathrm{H}) ;{ }^{13} \mathrm{C} \mathrm{NMR}\left(75 \mathrm{MHz}, \mathrm{CDCl}_{3}\right) \delta 195.0,170.3,146.9,146.3$, 145.1, 131.4, 127.6, 122.6, 115.0, 112.7, 86.0, 56.2, 52.2, 47.4, 41.5, 38.5; IR $\left(\mathrm{CDCl}_{3}\right)$ 1199, 1280, 1492, 1680, $1731 \mathrm{~cm}^{-1}$; MS (ESI) $\mathrm{m} / z: 311(\mathrm{M}+\mathrm{Na})^{+}$; HRMS (ESI) $\mathrm{m} / z$ calcd for $\mathrm{C}_{16} \mathrm{H}_{16} \mathrm{O}_{5} \mathrm{Na}^{+} 311.0895$, found 311.0878 .

Synthesis of 4-methoxy-10,11-dihydro-cyclohepta[c]chromene-6,9-dione (2a). A solution of 8methoxyspiro[chroman-4,1'-cyclohexa[2',5']diene]-2,4'-dione $\mathbf{1}^{30}(20 \mathrm{mg}, 0.078 \mathrm{mmol})$ in methanol $(0.6$ $\mathrm{mL}) / \mathrm{THF}(0.3 \mathrm{~mL})$ is added at $40{ }^{\circ} \mathrm{C}$ to a solution of sodium methoxide, freshly prepared from sodium $(13 \mathrm{mg}, 0.56 \mathrm{mmol})$ and methanol $(0.6 \mathrm{~mL})$. After stirring for $30 \mathrm{~min}$ at $40{ }^{\circ} \mathrm{C}$, the reaction is quenched with $1 \mathrm{M}$ hydrochloric acid $(2 \mathrm{~mL})$, stirred for $10 \mathrm{~min}$ and extracted with dichloromethane $(3 \mathrm{x} 5 \mathrm{~mL})$. Concentration in vacuo of the combined organic layers followed by preparative silica gel TLC (heptane / ethyl acetate 70 / 30) afforded $15 \mathrm{mg}$ of 4-methoxy-10,11-dihydro-cyclohepta[c]chromene-6,9-dione 2a (75\%): ${ }^{1} \mathrm{H}$ NMR $\left(500 \mathrm{MHz}, \mathrm{CDCl}_{3}\right) \delta 7.59(\mathrm{~d}, J=12.9 \mathrm{~Hz}, 1 \mathrm{H}), 7.39(\mathrm{~d}, J=8.35 \mathrm{~Hz}, 1 \mathrm{H}), 7.30$ (dd, $J=8.35,8.04 \mathrm{~Hz}, 1 \mathrm{H}), 7.18(\mathrm{~d}, J=8.04 \mathrm{~Hz}, 1 \mathrm{H}), 6.40(\mathrm{~d}, J=12.8 \mathrm{~Hz}, 1 \mathrm{H}), 4.01(\mathrm{~s}, 3 \mathrm{H}), 3.20$ (dd, $J=5.5,6.0 \mathrm{~Hz}, 2 \mathrm{H}), 2.83(\mathrm{dd}, J=5.6,6.1 \mathrm{~Hz}, 2 \mathrm{H}) ;{ }^{13} \mathrm{C} \mathrm{NMR}\left(125 \mathrm{MHz}, \mathrm{CDCl}_{3}\right) \delta 199.8,159.7,155.8$, 148.0, 143.4, 135.6, 132.0, 124.7, 121.5, 119.4, 116.7, 115.0, 56.6, 41.2, 22.7; IR $\left(\mathrm{CDCl}_{3}\right)$ 1469, 1662, $1710 \mathrm{~cm}^{-1}$; MS (ESI) $\mathrm{m} / z$ : $279(\mathrm{M}+\mathrm{Na})^{+}$; HRMS (ESI) $\mathrm{m} / z$ calcd for $\mathrm{C}_{15} \mathrm{H}_{12} \mathrm{O}_{4} \mathrm{Na}^{+} 279.0633$, found 279.0616.

Synthesis of 4-methoxy-7,8-dihydro-cyclohepta[c]chromene-6,9-dione (13a). A solution of 4methoxy-10,11-dihydro-cyclohepta[c]chromene-6,9-dione $2 \mathbf{a}(22 \mathrm{mg}, 0.086 \mathrm{mmol})$ in $p$-xylene $(1 \mathrm{~mL})$ is 
heated at $140{ }^{\circ} \mathrm{C}$ for $16 \mathrm{~h}$, concentrated in vacuo and the resulting mixture (ratio $\mathbf{2 a} / \mathbf{1 3 a}=3 / 1$ ) is purified by preparative silica gel TLC (eluting with heptane / ethyl acetate 40 / 60) to afford $2.5 \mathrm{mg}$ of 4methoxy-7,8-dihydro-cyclohepta[c]chromene-6,9-dione 13a $(11 \%):{ }^{1} \mathrm{H}$ NMR $\left(500 \mathrm{MHz}, \mathrm{CDCl}_{3}\right) \delta 7.42$ $(\mathrm{d}, J=12.8 \mathrm{~Hz}, 1 \mathrm{H}), 7.28(\mathrm{~m}, 2 \mathrm{H}), 7.14(\mathrm{dd}, J=7.0,2.1 \mathrm{~Hz}, 1 \mathrm{H}), 6.65(\mathrm{~d}, J=12.8 \mathrm{~Hz}, 1 \mathrm{H}), 4.01(\mathrm{~s}, 3 \mathrm{H})$, 3.17 (m, 2H), 2.84 (m, 2H); ${ }^{13} \mathrm{C}$ NMR (125 MHz, $\left.\mathrm{CDCl}_{3}\right)$ 200.9, 160.6, 147.7, 142.5, 142.1, 136.3, 132.5, 129.3, 124.4, 119.1, 115.0, 113.3, 56.3, 44.1, 20.9; IR $\left(\mathrm{CDCl}_{3}\right) 1473,1671,1707 \mathrm{~cm}^{-1}$; MS (ESI) $\mathrm{m} / z$ : $279(\mathrm{M}+\mathrm{Na})^{+}$; HRMS (ESI) $m / z$ calcd for $\mathrm{C}_{15} \mathrm{H}_{12} \mathrm{O}_{4} \mathrm{Na}^{+} 279.0633$, found 279.0631.

\section{Computational Methods}

Geometry optimization and vibrational frequency calculations were performed at the Density Functional Theory (DFT) level by using the Gaussian 03 program suite. ${ }^{34}$ Becke's three-parameter exchange functional (B3) ${ }^{60,61}$ was employed in conjunction with the Lee-Yang-Parr correlation functional (LYP), ${ }^{62}$ as implemented in Gaussian $03^{34}$ at a $6-31++\mathrm{G}(\mathrm{d}, \mathrm{p})$ basis set level. Geometries were optimized without constraint, and vibrational frequencies were then computed to characterize each structure as a minimum or transition structure (TS), via the number of imaginary frequencies (zero for minima and one for saddle points, respectively). After locating a TS, an intrinsic reaction coordinate (IRC) ${ }^{63-66}$ calculation was carried out to identify its respective reactant and product.

Acknowledgment. We thank the Institut de Chimie des Substances Naturelles (ICSN) and the Centre National de la Recherche Scientifique (CNRS) for the financial support.

Supporting Information Available. Spectral characterization of compounds 3, 2a and 13a, equilibrium between different intermediates and deuterium labeling followed by NMR, detailed data for the X-ray structure of compound $\mathbf{2 a}$, theoretical data for calculated compounds, intermediates and transition states, a movie generated from the IRC calculations showing the first part of the mechanism. This material is available free of charge via the Internet at http://pubs.acs.org.

\section{References}

$\S$ Parts of this work were presented at the $1^{\text {st }}$ European Chemistry Congress, 27-31 August 2006, Abstract p. 326.

(1) Miyashita, M.; Hara, S.; Yoshikoshi, A. J. Org. Chem. 1987, 52, 2602-2604. 
(2) Ley, S. V.; Antonello, A.; Balskus, E. P.; Booth, D. T.; Christensen, S. B.; Cleator, E.; Gold, H.; Högenauer, K.; Hünger, U.; Myers, R. M.; Oliver, S. F.; Simic, O.; Smith, M. D.; Sohoel, H.; Woolford, A. J. A. Proc. Natl. Acad. Sci. U. S. A. 2004, 101, 12073-12078.

(3) Graening, T.; Schmalz, H.-G. Angew. Chem., Int. Ed. 2004, 43, 3230-3256.

(4) Graening, T.; Bette, V.; Neudoerfl, J.; Lex, J.; Schmalz, H.-G. Org. Lett. 2005, 7, 4317-4320.

(5) Pietra, F. Chem. Rev. 1973, 73, 293-364.

(6) Banwell, M. G. Aust. J. Chem. 1991, 44, 1-36.

(7) Battiste, M. A.; Pelphrey, P. M.; Wright, D. L. Chem.--Eur. J. 2006, 12, 3438-3447.

(8) Noyori, R. Acc. Chem. Res. 1979, 12, 61-66.

(9) Noyori, R.; Hayakawa, Y. Org. React. 1983, 29, 163-344.

(10) Hoffmann, H. M. R. Angew. Chem., Int. Ed. Engl. 1984, 23, 29-48.

(11) Herndon, J. W.; Chatterjee, G.; Patel, P. P.; Matasi, J. J.; Tumer, S. U.; Harp, J. J.; Reid, M. D. J. Am. Chem. Soc. 1991, 113, 7808-7809.

(12) Herndon, J. W.; Zora, M.; Patel, P. P.; Chatterjee, G.; Matasi, J. J.; Tumer, S. U. Tetrahedron 1993, 49, 5507-5530.

(13) Herndon, J. W.; Zora, M. Synlett 1993, 363-364.

(14) Barluenga, J.; Aznar, F.; Martin, A.; Vazquez, J. T. J. Am. Chem. Soc. 1995, 117, 9419-9426.

(15) Barluenga, J.; Barrio, P.; Lopez, L. A.; Tomas, M.; Garcia-Granda, S.; Alvarez-Rua, C. Angew. Chem., Int. Ed. 2003, 42, 3008-3011.

(16) Ni, Y.; Montgomery, J. J. Am. Chem. Soc. 2004, 126, 11162-11163.

(17) Barluenga, J.; Vicente, R.; Barrio, P.; Lopez, L. A.; Tomas, M.; Borge, J. J. Am. Chem. Soc. 2004, $126,14354-14355$.

(18) Barluenga, J.; Alonso, J.; Fananas, F. J. Chem.--Eur. J. 2005, 11, 4995-5006.

(19) Trost, B. M.; Shen, H. C.; Horne, D. B.; Toste, F. D.; Steinmetz, B. G.; Koradin, C. Chem.--Eur. J. 2005, 11, 2577-2590.

(20) Zora, M.; Acikgoez, C.; Odabasoglu, M.; Bueyuekguengoer, O. J. Organomet. Chem. 2007, 692, 1571-1578.

(21) Sperry, J. B.; Wright, D. L. J. Am. Chem. Soc. 2005, 127, 8034-8035.

(22) Dowd, P.; Choi, S. C. J. Am. Chem. Soc. 1987, 109, 3493-3494.

(23) Baldwin, J. E.; Adlington, R. M.; Robertson, J. Tetrahedron 1989, 45, 909-922. 
(24) Dowd, P.; Zhang, W. J. Org. Chem. 1992, 57, 7163-7171.

(25) Evans, D. A.; Hart, D. J.; Koelsch, P. M. J. Am. Chem. Soc. 1978, 100, 4593-4594.

(26) Evans, D. A.; Tanis, S. P.; Hart, D. J. J. Am. Chem. Soc. 1981, 103, 5813-5821.

(27) Rogers, D. H.; Frey, B.; Roden, F. S.; Russkamp, F.-W.; Willis, A. C.; Mander, L. N. Aust. J. Chem. 1999, 52, 1093-1108.

(28) Frey, B.; Wells, A. P.; Roden, F.; Au, T. D.; Hockless, D. C.; Willis, A. C.; Mander, L. N. Aust. J. Chem. 2000, 53, 819-830.

(29) During the preparation of this manuscript, a short paper describing a similar rearrangement has been published : Moisan, L.; Wagner, M.; Comesse, S.; Doris, E. Tetrahedron Lett. 2006, 47, 9093-9094.

(30) Guillou, C.; Beunard, J.-L.; Gras, E.; Thal, C. Angew. Chem., Int. Ed. 2001, 40, 4745-4746.

(31) The compound $\mathbf{3}$ can be prepared in a straightforward manner in acidic medium (TFA, MeOH) from spirocyclohexadienone 1 in $87 \%$ yield (see Experimental Section).

(32) The compound 9 is the anionic phenoxide form rather than the neutral phenol form, as indicated by the important shift of the aromatic protons observed in its ${ }^{1} \mathrm{H}-\mathrm{NMR}$ spectrum, see Highet, R. J.; Highet, P. F. J. Org. Chem. 1965, 30, 902-906.

(33) A single example of fused tricyclic cyclopropane intermediate similar to $\mathbf{1 1}$ has been previously proposed as intermediate in the transformation of phenolic nitroalkanes into tropone derivatives, but the reaction conditions and the overall mechanism are different from ours, which lead to the dihydrotropone derivative 2a : Kende, A. S.; Koch, K. Tetrahedron Lett. 1986, 27, 6051-6054.

(34) Frisch, M. J.; Trucks, G. W.; Schlegel, H. B.; Scuseria, G. E.; Robb, M. A.; Cheeseman, J. R.; Montgomery, J., J. A.; Vreven, T.; Kudin, K. N.; Burant, J. C.; Millam, J. M.; Iyengar, S. S.; Tomasi, J.; Barone, V.; Mennucci, B.; Cossi, M.; Scalmani, G.; Rega, N.; Petersson, G. A.; Nakatsuji, H.; Hada, M.; Ehara, M.; Toyota, K.; Fukuda, R.; Hasegawa, J.; Ishida, M.; Nakajima, T.; Honda, Y.; Kitao, O.; Nakai, H.; Klene, M.; Li, X.; Knox, J. E.; Hratchian, H. P.; Cross, J. B.; Bakken, V.; Adamo, C.; Jaramillo, J.; Gomperts, R.; Stratmann, R. E.; Yazyev, O.; Austin, A. J.; Cammi, R.; Pomelli, C.; Ochterski, J. W.; Ayala, P. Y.; Morokuma, K.; Voth, G. A.; Salvador, P.; Dannenberg, J. J.; Zakrzewski, V. G.; Dapprich, S.; Daniels, A. D.; Strain, M. C.; Farkas, O.; Malick, D. K.; Rabuck, A. D.; Raghavachari, K.; Foresman, J. B.; Ortiz, J. V.; Cui, Q.; Baboul, A. G.; Clifford, S.; Cioslowski, J.; Stefanov, B. B.; Liu, G.; Liashenko, A.; Piskorz, P.; Komaromi, I.; 
Martin, R. L.; Fox, D. J.; Keith, T.; Al-Laham, M. A.; Peng, C. Y.; Nanayakkara, A.; Challacombe, M.; Gill, P. M. W.; Johnson, B.; Chen, W.; Wong, M. W.; Gonzalez, C.; Pople, J. A.; Gaussian 03 revision B.05; Gaussian, Inc., Wallingford CT; 2004.

(35) Spangler, C. W. Chem. Rev. 1976, 76, 187-217.

(36) Houk, K. N.; Li, Y.; Evanseck, J. D. Angew. Chem. Int. Ed. Engl. 1992, 31, 682-708.

(37) Hudson, C. E.; McAdoo, D. J. J. Org. Chem. 2003, 68, 2735-2740.

(38) Donovan, W. H.; White, W. E. J. Org. Chem. 1996, 61, 969-977.

(39) Okajima, T.; Imafuku, K. J. Org. Chem. 2002, 67, 625-632.

(40) In the search for the transition states TS3n, TS3a and TS5n, several initial structures were tested. In some cases, local maximums were found (one negative frequence), but the IRC calculations did not lead to the expected reactants or products. This is probably due to the constraints induced by the cyclic form of the system.

(41) Lew, C. S. Q.; Tang, T.-H.; Cxizmadia, I. G.; Capon, B. J. Chem. Soc., Chem. Commun. 1995, $175-176$.

(42) McKervey, M. A.; Tuladhar, S. M.; Twohig, M. F. J. Chem. Soc., Chem. Commun. 1984, 129-130.

(43) Kennedy, M.; McKervey, M. A.; Maguire, A. R.; Tuladhar, S. M.; Twohig, M. F. J. Chem. Soc., Perkin Trans. 1 1990, 1047-1054.

(44) Manitto, P.; Monti, D.; Zanzola, S.; Speranza, G. Chem. Commun. 1999, 543-544.

(45) Saraçoglu, N.; Menzek, A.; Kinal, A.; Balci, M. Can. J. Chem. 2001, 79, 35-41.

(46) Swenton, J. S.; Burdett, K. A.; Madigan, D. M.; Rosso, P. D. J. Org. Chem. 1975, 40, 1280-1286.

(47) Pomerantz, M.; Dassanayake, N. L. J. Am. Chem. Soc. 1980, 102, 678-682.

(48) Takahashi, K.; Yamamoto, H.; Nozoe, T. Bull. Chem. Soc. Jpn. 1970, 43, 200-207.

(49) Takahashi, K.; Suzuki, T.; Toda, H.; Takase, K.; Koseki, S.; Nakajima, T. J. Org. Chem. 1987, 52, 2666-2673.

(50) Zwaard, A. W.; Kloosterziel, H. Recl. Trav. Chim. Pays-Bas 1981, 100, 126-128.

(51) Zwaard, A. W.; Prins, M. D.; Kloosterziel, H. Recl. Trav. Chim. Pays-Bas 1984, 103, 174-176.

(52) Zwaard, A. W.; Prins, M. D.; Kloosterziel, H. Recl. Trav. Chim. Pays-Bas 1984, 103, 188-192.

(53) Ledon, H.; Cannic, G.; Linstrumelle, G.; Julia, S. Tetrahedron Lett. 1970, 11, 3971-3974.

(54) Iwata, C.; Yamada, M.; Shinoo, Y.; Kobayashi, K.; Okada, H. J. Chem. Soc., Chem. Commun. 1977, 888-889. 
(55) Iwata, C.; Yamada, M.; Shinoo, Y.; Kobayashi, K.; Okada, H. Chem. Pharm. Bull. 1980, 28, 19321934.

(56) Scott, L. T.; Minton, M. A.; Kirms, M. A. J. Am. Chem. Soc. 1980, 102, 6311-6314.

(57) Machiguchi, T.; Hasegawa, T.; Otani, H.; Ishii, Y. J. Chem. Soc., Chem. Commun. 1987, 13751376.

(58) Ishizu, T.; Mori, M.; Kanematsu, K. J. Org. Chem. 1981, 46, 526-531.

(59) Duddeck, H.; Kennedy, M.; McKervey, M. A.; Twohig, F. M. J. Chem. Soc., Chem. Commun. 1988, 1586-1588.

(60) Becke, A. D. J. Chem. Phys. 1993, 98, 1372-1377.

(61) Becke, A. D. J. Chem. Phys. 1993, 98, 5648-5652.

(62) Lee, C.; Yang, W.; Parr, R. G. Phys. Rev. B. Condens. Matter Mater. Phys. 1988, 37, 785-789.

(63) Ishida, K.; Morokuma, K.; Komornicki, A. J. Chem. Phys. 1977, 66, 2153-2156.

(64) Fukui, K. Acc. Chem. Res. 1981, 14, 363-368.

(65) Gonzalez, C.; Schlegel, H. B. J. Chem. Phys. 1989, 90, 2154-2161.

(66) Gonzalez, C.; Schlegel, H. B. J. Phys. Chem. 1990, 94, 5523-5527. 
Supporting Information

\section{A new access to dihydrotropones through ring expansion of spirocyclohexadienones: Synthesis and mechanism}

Marie Varin, Angèle Chiaroni, Jean-Yves Lallemand, Bogdan Iorga, Catherine Guillou Institut de Chimie des Substances Naturelles, CNRS UPR 2301, F-91198 Gif sur Yvette, France

Table of contents :

${ }^{1} \mathrm{H}$ and ${ }^{13} \mathrm{C}$-NMR spectra of compound 3

${ }^{1} \mathrm{H}$ and ${ }^{13} \mathrm{C}$-NMR spectra of compound 2a

${ }^{1} \mathrm{H}$ and ${ }^{13} \mathrm{C}$-NMR spectra of compound 13a S6

Evolution of the reaction followed by ${ }^{1} \mathrm{H}-\mathrm{NMR} \quad S 8$

X-ray structure analysis of compound 2a $\quad S 11$

$\begin{array}{ll}\text { Theoretical data for intermediates and transition states } & \text { S19 }\end{array}$ 


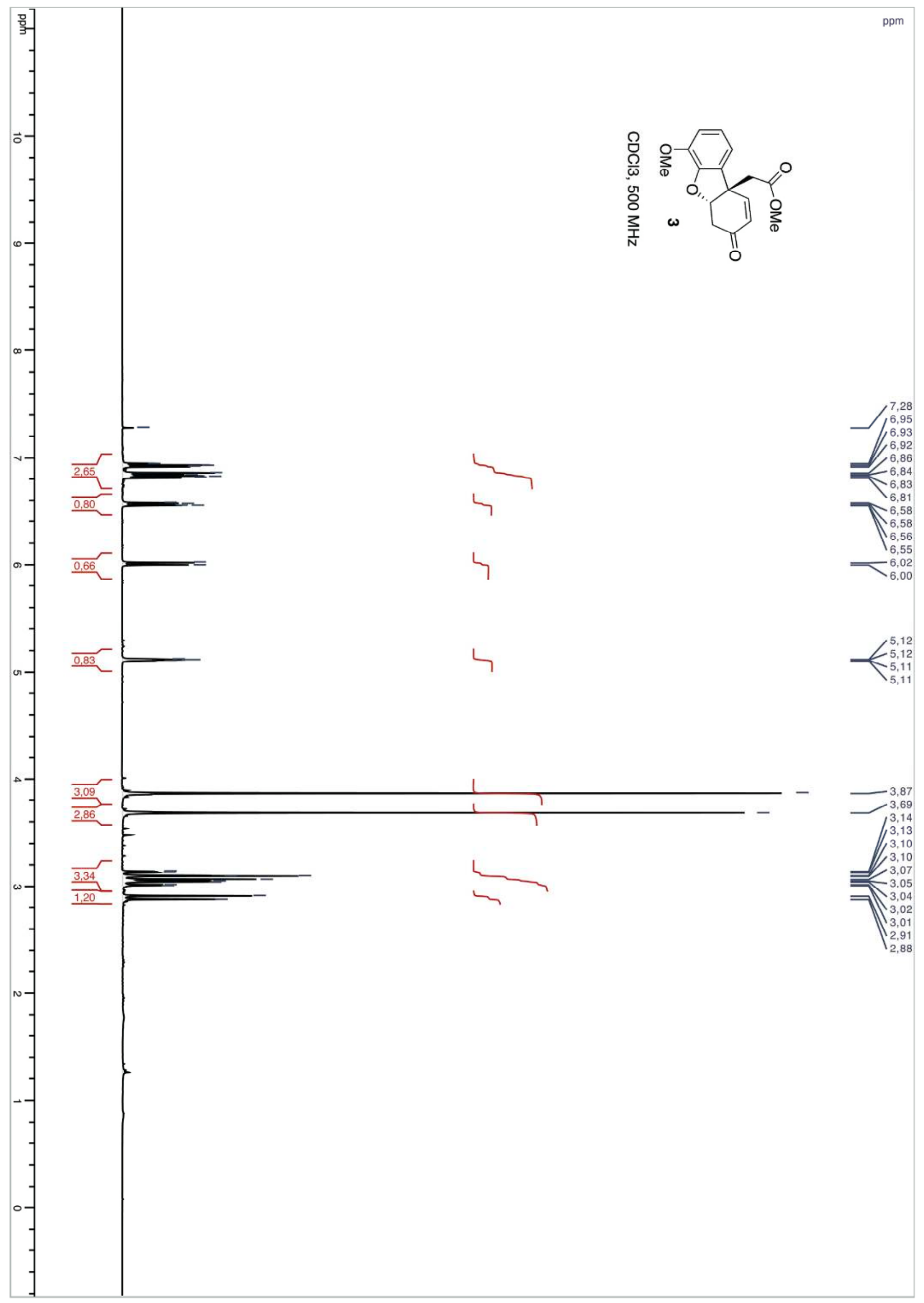




$$
\mid
$$




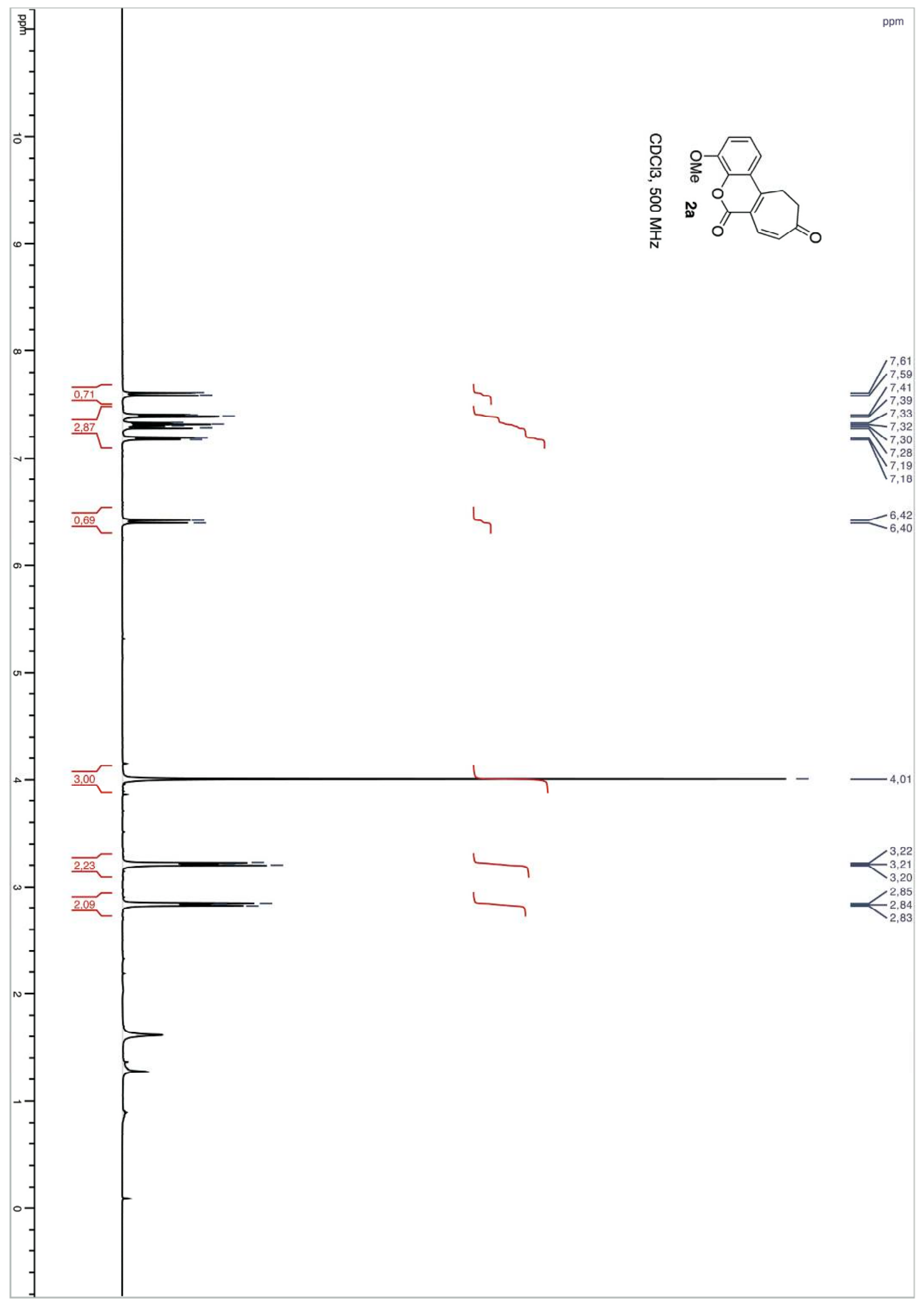




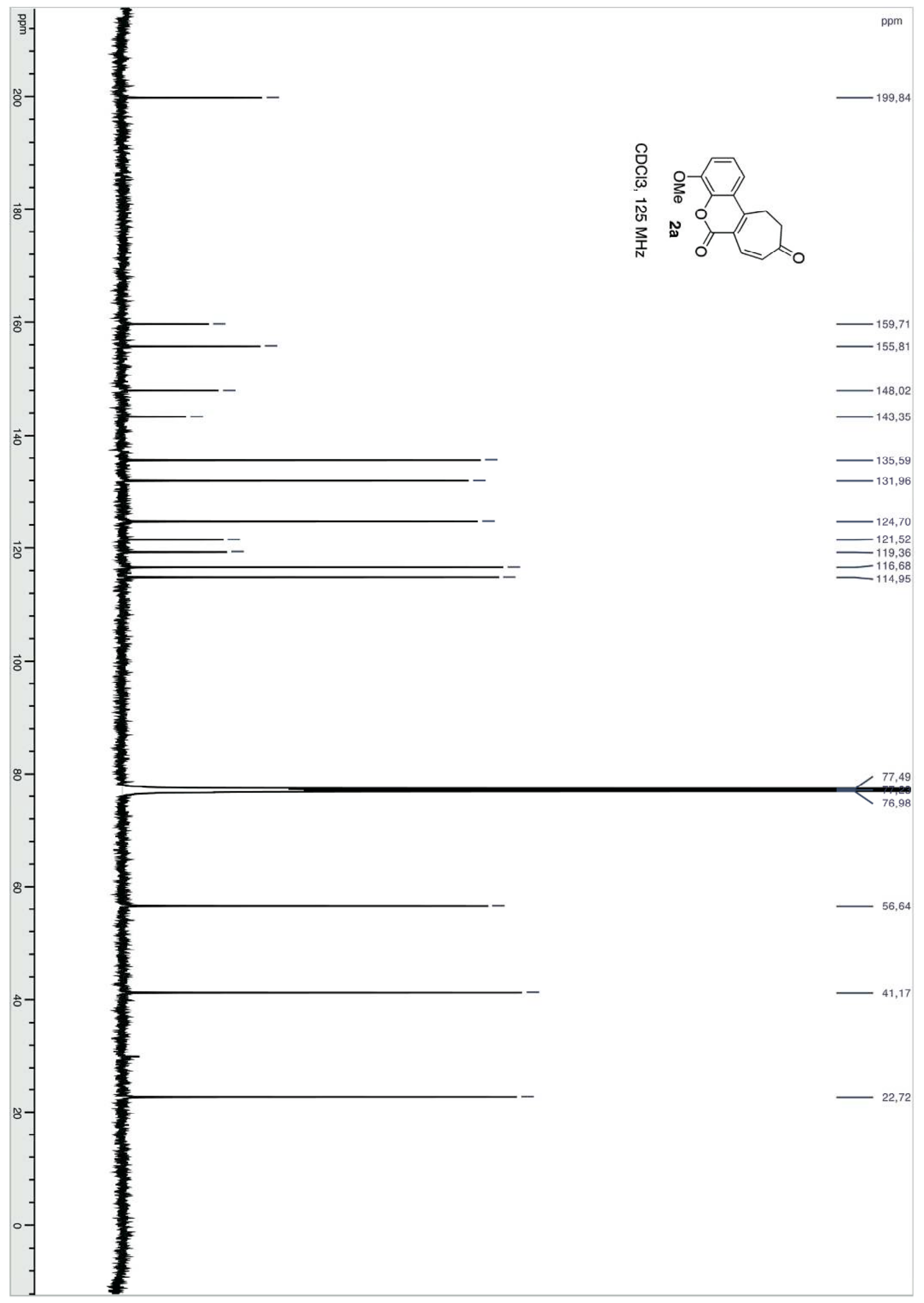




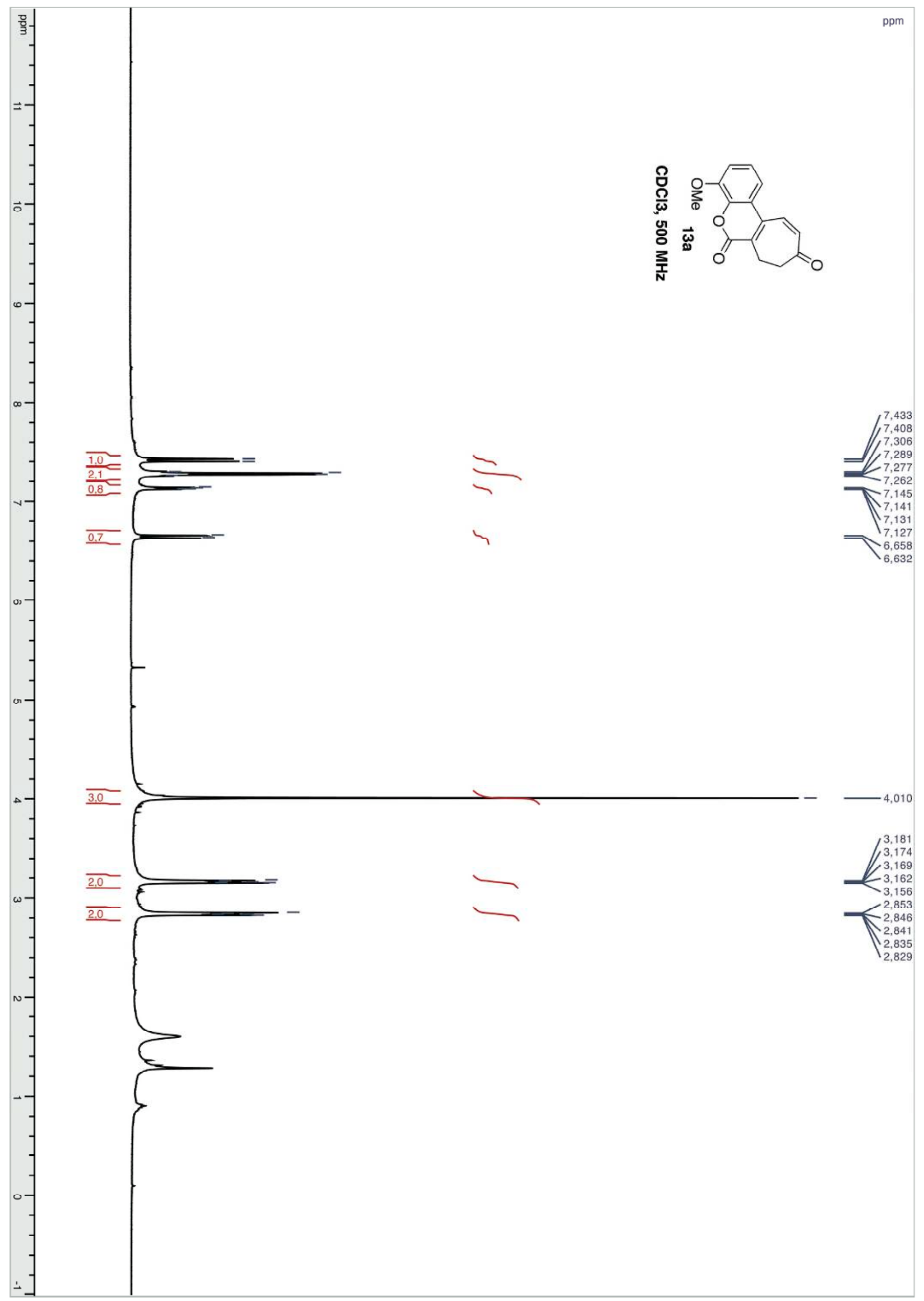




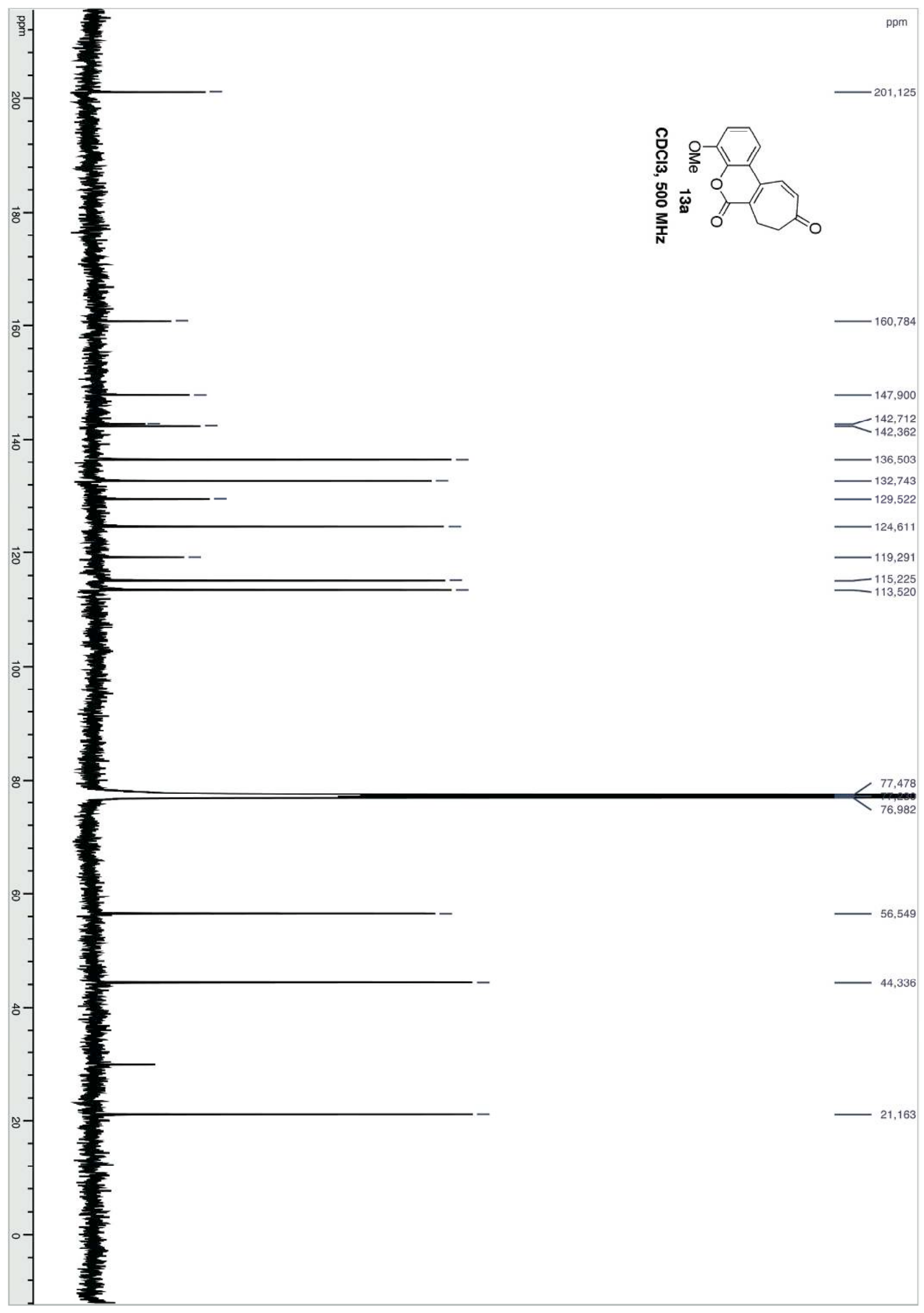




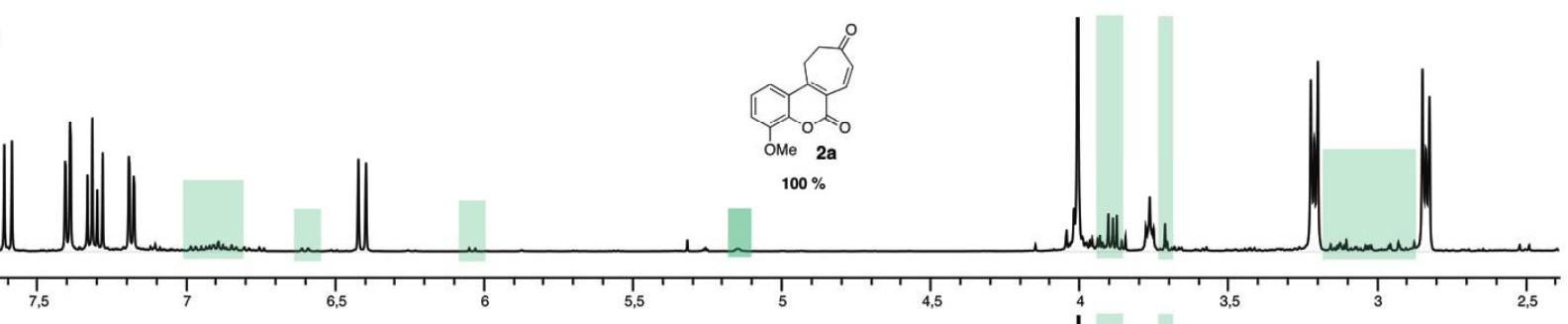

$6 \min$

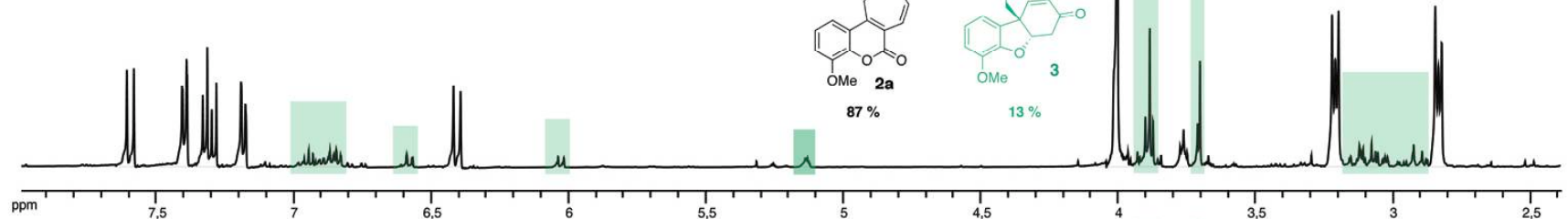

$3 \min$
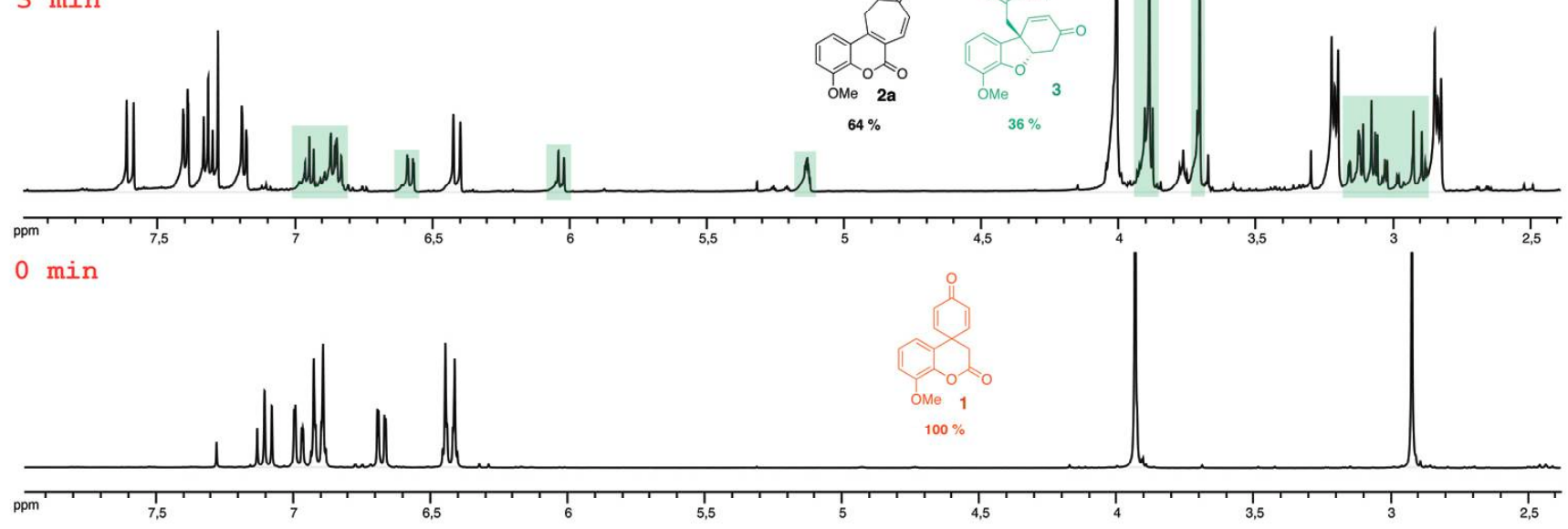

Figure S1. Superposed ${ }^{1} \mathrm{H}-\mathrm{NMR}$ spectra $\left(500 \mathrm{MHz}, \mathrm{CDCl}_{3}\right)$ of reaction mixture (from the reaction of 1 with $\mathrm{MeONa}$ in $\mathrm{MeOH}$ at $40^{\circ} \mathrm{C}$ ) after acidic quench at different times. The competitive formation of $\mathbf{2} \mathbf{a}$ and $\mathbf{3}$ (green) is observed, then the conversion of $\mathbf{3}$ in $\mathbf{2 a}$. The rearrangement product $\mathbf{2 a}$ is obtained almost exclusively after $30 \mathrm{~min}$. 


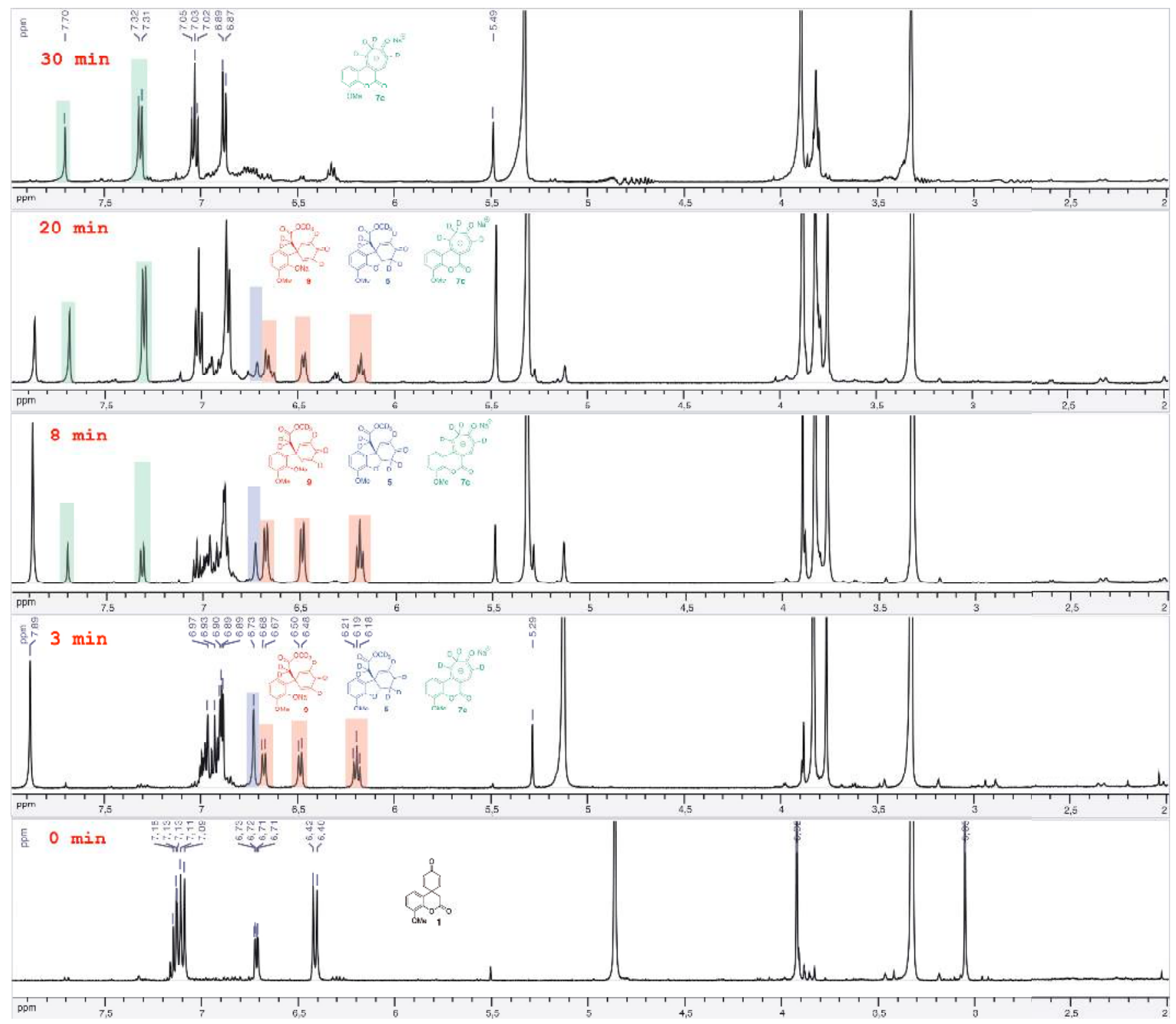

Figure S2. Superposed ${ }^{1} \mathrm{H}-\mathrm{NMR}$ spectra $\left(500 \mathrm{MHz}, \mathrm{CD}_{3} \mathrm{OD}\right)$ of intermediates from the reaction of $\mathbf{1}$ with $\mathrm{CD}_{3} \mathrm{ONa}$ in $\mathrm{CD}_{3} \mathrm{OD}$ at $40^{\circ} \mathrm{C}$. The competitive formation of the ester $\mathbf{5}$, phenoxide 9 and 7 -membered ring anion $7 \mathrm{c}$ is observed. The equilibrium is shifted almost completely towards the more thermodynamically stable anion $7 \mathrm{c}$ after $30 \mathrm{~min}$. 


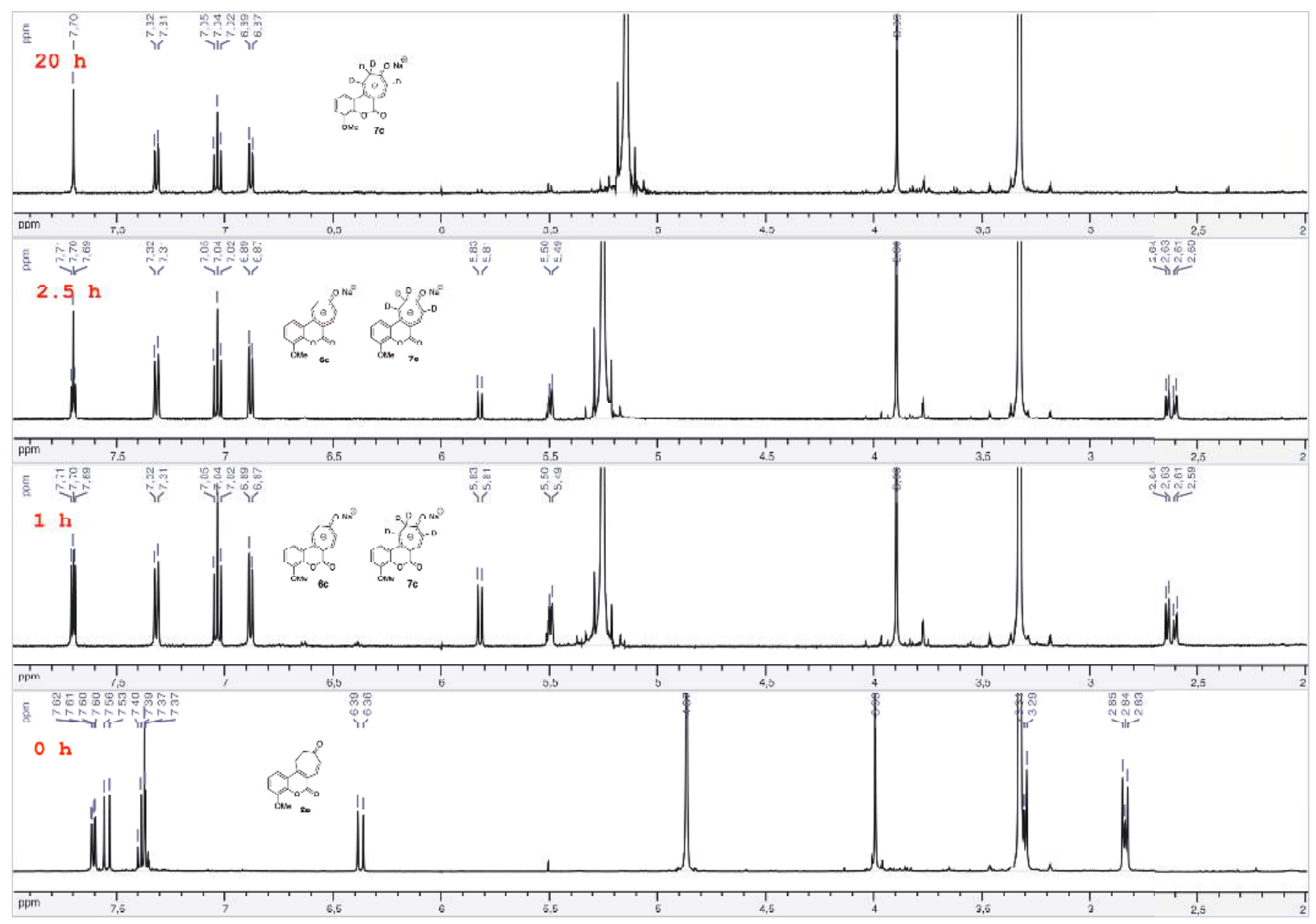

Figure S3. Superposed ${ }^{1} \mathrm{H}-\mathrm{NMR}$ spectra $\left(500 \mathrm{MHz}, \mathrm{CD}_{3} \mathrm{OD}\right)$ of intermediates from the reaction of $2 \mathbf{a}$ with $\mathrm{CD}_{3} \mathrm{ONa}$ in $\mathrm{CD}_{3} \mathrm{OD}$ at room temperature. We observe the immediate formation of the anion $6 \mathrm{c}$, which is progressively deuterated, leading to the complete formation of the anion $7 \mathrm{c}$ after $20 \mathrm{~h}$. 


\section{X-RAY STRUCTURE ANALYSIS OF COMPOUND 2A}

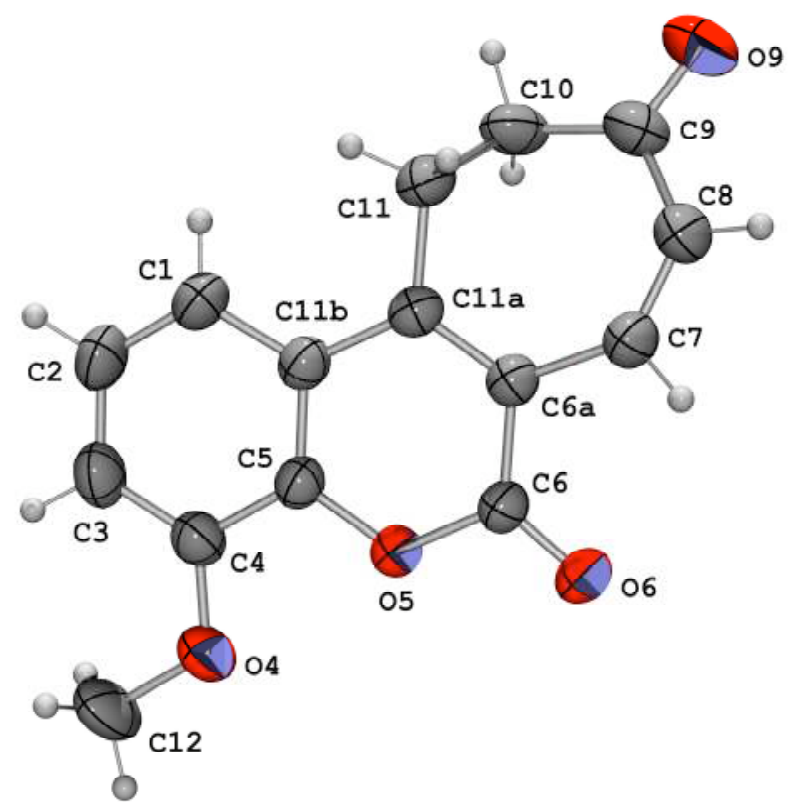

Figure S4. ORTEP drawing of the X-ray structure of 2a shown as displacement ellipsoids at the $30 \%$ probability level
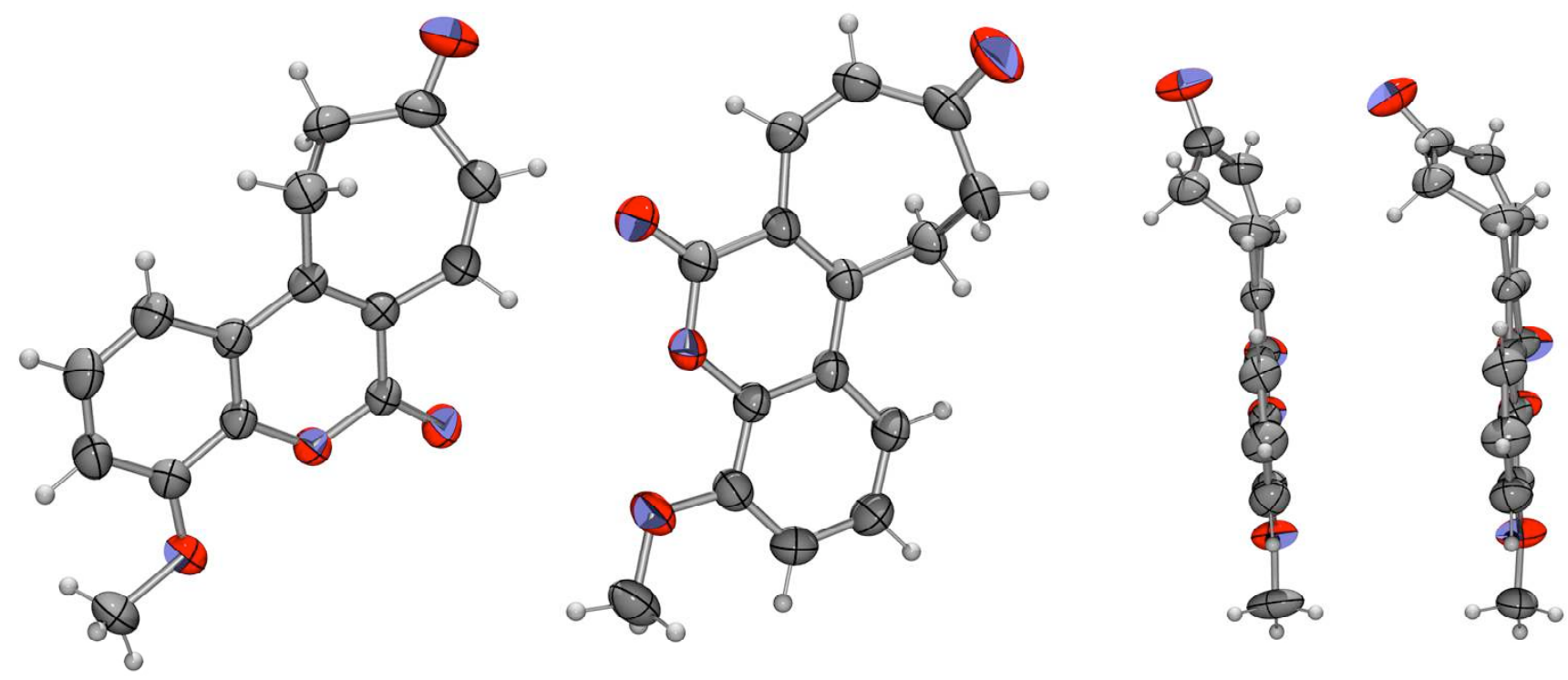

Figure S5. ORTEP drawing of the asymmetric unit (left) and deviations of the atoms C8, C9, C10 and O9 from the molecule plane for the two molecules in the asymmetric unit. Displacement ellipsoids are shown at the $30 \%$ probability level.

Crystals suitable for an X-ray study have been obtained for the 6,7-dihydrotropone 2a and the tridimensional structure is shown in Figure S4. All atoms are coplanar except the atoms C8, C9, C10 and O9. There are two independent molecules in the asymmetric unit, the main difference between them being the degree of deviation of the atoms C8, C9, C10 and O9 from the molecule plane (Figure S5). 
Crystallographic results. Data were obtained from a small colorless crystal plate $(0.55 \times 0.50 \times 0.20 \mathrm{~mm})$. Empirical formula : $\mathrm{C}_{15} \mathrm{H}_{12} \mathrm{O}_{4}, \mathrm{M}_{\mathrm{w}}=256.25$. The compound crystallizes in the triclinic system, space group P-1, racemic. There are four molecules in the unit-cell $(\mathrm{Z}=4)$ and so, two independent molecules in the asymmetric unit. Cell parameters : $a=7.510(5), b=12.824(5), c=13.261(7) \AA, \alpha=73.61(3), \beta=$

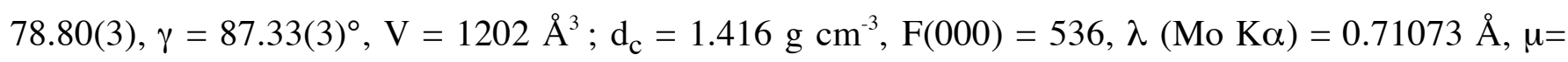
$0.103 \mathrm{~mm}^{-1}$. Data were measured with a Nonius Kappa-CCD linear area-detector diffractometer, using graphite monochromated Mo K $\alpha$ radiation, according to the phi and omega scan method, up to $\theta=$ $27.50^{\circ}$. A total of 9306 intensity data was collected reduced to 7000 triclinic reflections of which 5273 were unique $(\mathrm{Rint}=0.020) .{ }^{1}$ Structure was solved with program $S H E L X S 86^{2}$ and refined by full-matrix least-squares, upon all unique $\mathrm{F}^{2}$ with program SHELXL97. ${ }^{3}$ All the hydrogen atoms were located in difference Fourier maps. They were fitted at theoretical positions and treated as riding, assigned of an isotropic displacement parameter equivalent to 1.12 the one of the bonded atom, 1.15 for those of the methyl groups. Refinement of 345 parameters converged to $\mathrm{R} 1(\mathrm{~F})=0.0486$ with the 3639 observed reflections having $\mathrm{I} \geq 2$ sigma $(\mathrm{I})$ and $\mathrm{wR} 2\left(\mathrm{~F}^{2}\right)=0.1272$ with all the 5273 unique data; goodness-of-fit $\mathrm{S}$ factor of 1.024. The residual electron density was found between -0.18 and $0.19 \mathrm{e}^{-3}$. All the crystallographic results are given in Cif file and Tables S1 to S6.

Comparison of molecular conformations. The two independent molecules of the asymmetric unit named respectively, * and **, appear in Figure S5, showing the same diastereoisomer. In both molecules, bond distance and angle values are nearly the same with double bonds C6a-C11a (1.362 A) and C7-C8 (av. $1.341 \AA$ ) clearly precised. However, differences appear in torsion angle values of the seven membered rings principally along the bonds: C8-C9 (-6.1 in *, $-28.1^{\circ}$ in **), C9-C10 (-43.7 and $\left.-19.0^{\circ}\right)$ and $\mathrm{C} 10$ C11 (76.9 and 86.2), indicating differences in the ring conformations. Fitting the two structures, atoms C7 and C11 are quitely coplanar with the bicyclic aromatic part in each molecule, while atoms C8, C9 and C10 are respectively deviated by $0.226(2), 0.885(2)$ and $1.183(2) \AA$ in *, by $0.500(2), 1.372(2)$ and 1.284(2) $\AA$ in **, from the mean plane of the other twelve atoms. If atom C8 is included in the aromatic mean plane, deviations of atoms C9 and C10 become : 0.800(2) and 1.114(2) $\AA$ in *,1.180(2) and 1.144 (2) $\AA$ - nearly the same - in **. So, the angles between the planes [C11, C11a, C6a, C7, C8] and [C8, C9, $\mathrm{C} 10, \mathrm{C} 11]$ in the seven membered rings, are respectively $136.3^{\circ}$ in $* 131.0^{\circ}$ in $* *$. More, if we consider only the mean plane of the double bonds involving atoms [C11a, C6a, C7, C8, C9], atoms C10 and C11 are deviated from this plane by respectively $0.327(2)$ and $-0.620(2) \AA$ in *, while atom C10 lies in this plane in **, with C11 situated below by $-0.890(2) \AA$. The crystal packing study shows that only van der Waals contacts exist between the molecules.

\footnotetext{
${ }^{1}$ Collect (Nonius BV, 1997-2000); HKL Denzo and Scalepack (Otinowski \& Minor, 1997).

${ }^{2}$ Sheldrick, G.M. (1990). SHELXS86. Acta Cryst. A 46, 467-473.

${ }^{3}$ Sheldrick, G.M. (1997). SHELX97. Program for the Refinement of Crystal Structures, Univ. of Göttingen, Germany.
} 
Table s1. Crystal data and structure refinement for compound $\mathbf{2 a}$.

\begin{tabular}{|c|c|}
\hline Identification code & 'VARIN051' \\
\hline Empirical formula & C15 H12 O4 \\
\hline Formula weight & 256.25 \\
\hline Temperature & $293(2) \mathrm{K}$ \\
\hline Wavelength & $0.71073 \mathrm{~A}$ \\
\hline Crystal system, space group & Triclinic, $\quad P-1$ \\
\hline Unit cell dimensions & $\begin{array}{llll}\mathrm{a}=7.510(5) \mathrm{A} & \text { alpha }=73.61(3) \text { deg. } \\
\mathrm{b}=12.824(5) \mathrm{A} & \text { beta }=78.80(3) \text { deg. } \\
\mathrm{C}=13.261(7) \mathrm{A} & \text { gamma }=87.33(3) \text { deg. }\end{array}$ \\
\hline Volume & $1201.9(11) A^{\wedge} 3$ \\
\hline z, Z', Calculated density & $4,2,1.416 \mathrm{Mg} / \mathrm{m}^{\wedge} 3$ \\
\hline Absorption coefficient & $0.103 \mathrm{~mm}^{\wedge}-1$ \\
\hline$F(000)$ & 536 \\
\hline Crystal size & $0.55 \times 0.50 \times 0.20 \mathrm{~mm}$ \\
\hline Theta range for data collection & 2.76 to $27.50 \mathrm{deg}$. \\
\hline Limiting indices & $-9<=\mathrm{h}<=9, \quad-16<=\mathrm{k}<=16, \quad-16<=1<=17$ \\
\hline Reflections collected / unique & $9306-7000 / 5273[R($ int $)=0.0199]$ \\
\hline Completeness to theta $=27.50$ & $95.3 \%$ \\
\hline Absorption correction & Not measured \\
\hline Refinement method & Full-matrix least-squares on $\mathrm{F}^{\wedge} 2$ \\
\hline Data / restraints / parameters & $5273 / 0 / 345$ \\
\hline Goodness-of-fit on $F^{\wedge} 2$ & 1.024 \\
\hline Final $R$ indices [I>2sigma(I)] & $\mathrm{R} 1=0.0486, \mathrm{wR} 2=0.1101(3639 \mathrm{FO})$ \\
\hline $\mathrm{R}$ indices (all data) & $\mathrm{R} 1=0.0779, \mathrm{wR} 2=0.1272(5273$ data $)$ \\
\hline Largest diff. peak and hole & 0.187 and -0.177 e. $A^{\wedge}-3$ \\
\hline
\end{tabular}


Table s2. Atomic coordinates $\left(x 10^{\wedge} 4\right)$ and equivalent isotropic displacement parameters $\left(A^{\wedge} 2 \times 10^{\wedge} 3\right)$ for compound $2 a$.

$\mathrm{U}(\mathrm{eq})$ is defined as one third of the trace of the orthogonalized Uij tensor. (* Molecule 1, ** Molecule 2)

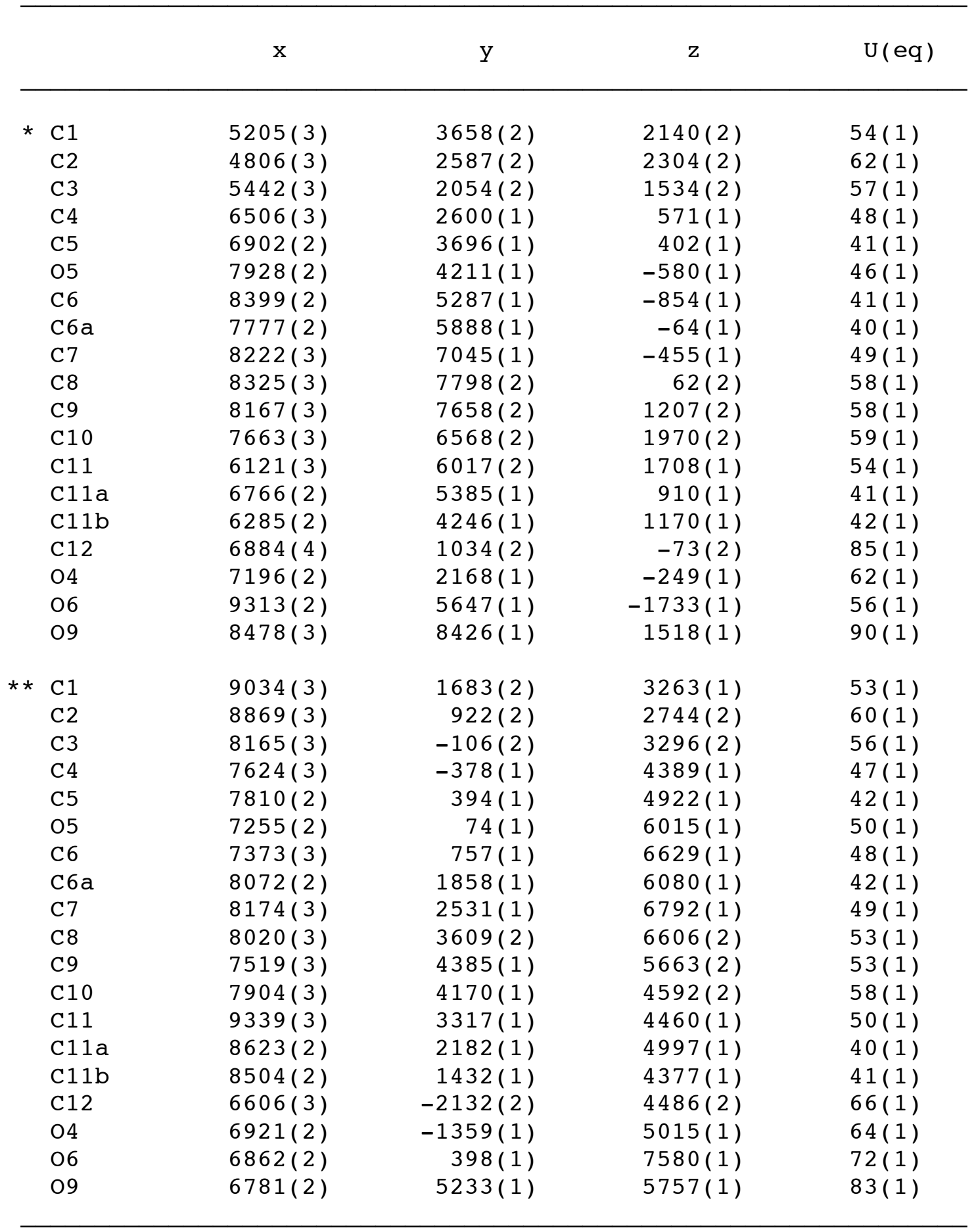


Table s5. Bond lengths [A] and angles [deg] for compound 2a.

\begin{tabular}{|c|c|}
\hline$C 1-C 2$ & \\
\hline $\mathrm{C} 1-\mathrm{C} 2$ & $\begin{array}{l}1.367(3) \\
1.409(3)\end{array}$ \\
\hline $\mathrm{C} 1-\mathrm{C} 11 \mathrm{~b}$ & $1.409(3)$ \\
\hline $\mathrm{C} 2-\mathrm{C} 3$ & $1.383(3)$ \\
\hline $\mathrm{C} 3-\mathrm{C} 4$ & $1.382(3)$ \\
\hline $\mathrm{C} 4-\mathrm{O} 4$ & $1.361(2)$ \\
\hline $\mathrm{C} 4-\mathrm{C} 5$ & $1.397(2)$ \\
\hline C5-O5 & $1.378(2)$ \\
\hline $\mathrm{C} 5-\mathrm{C} 11 \mathrm{~b}$ & $1.393(2)$ \\
\hline O5-C6 & $1.369(2)$ \\
\hline $\mathrm{C} 6-06$ & $1.207(2)$ \\
\hline $\mathrm{c} 6-\mathrm{C} 6 \mathrm{a}$ & $1.464(2)$ \\
\hline C6a-C11a & $1.362(2)$ \\
\hline $\mathrm{C} 6 \mathrm{a}-\mathrm{C} 7$ & $1.458(2)$ \\
\hline $\mathrm{C} 7-\mathrm{C} 8$ & $1.345(2)$ \\
\hline $\mathrm{C} 8-\mathrm{C} 9$ & $1.460(3)$ \\
\hline C9-09 & $1.218(2)$ \\
\hline $\mathrm{C} 9-\mathrm{C} 10$ & $1.491(3)$ \\
\hline $\mathrm{C} 10-\mathrm{C} 11$ & $1.526(3)$ \\
\hline C11-C11a & $1.504(2)$ \\
\hline $\mathrm{C} 11 \mathrm{a}-\mathrm{C} 11 \mathrm{~b}$ & $1.449(2)$ \\
\hline C12-04 & $1.429(2)$ \\
\hline * $\mathrm{C} 2-\mathrm{C} 1-\mathrm{C} 11 \mathrm{~b}$ & $120.08(18)$ \\
\hline $\mathrm{C} 1-\mathrm{C} 2-\mathrm{C} 3$ & $121.49(18)$ \\
\hline $\mathrm{C} 4-\mathrm{C} 3-\mathrm{C} 2$ & $120.31(17)$ \\
\hline $\mathrm{O} 4-\mathrm{C} 4-\mathrm{C} 3$ & $125.72(16)$ \\
\hline $\mathrm{O} 4-\mathrm{C} 4-\mathrm{C} 5$ & $116.13(16)$ \\
\hline C3-C4-C51 & $118.15(16)$ \\
\hline $05-C 5-C 11 b$ & $121.67(15)$ \\
\hline $\mathrm{O} 5-\mathrm{C} 5-\mathrm{C} 4$ & $115.90(15)$ \\
\hline $\mathrm{C} 11 \mathrm{~b}-\mathrm{C} 5-\mathrm{C} 4$ & $122.42(16)$ \\
\hline $\mathrm{C} 6-05-\mathrm{C} 5$ & $121.93(13)$ \\
\hline $\mathrm{O} 6-\mathrm{C} 6-05$ & $116.09(14)$ \\
\hline $06-C 6-C 6 a$ & $126.08(15)$ \\
\hline $05-C 6-C 6 a$ & $117.83(14)$ \\
\hline $\mathrm{C} 11 \mathrm{a}-\mathrm{C} 6 \mathrm{a}-\mathrm{C} 7$ & $125.30(15)$ \\
\hline C11a-C6a-C6 & $120.60(15)$ \\
\hline $\mathrm{C} 7-\mathrm{C} 6 \mathrm{a}-\mathrm{C} 6$ & $113.93(15)$ \\
\hline $\mathrm{C} 8-\mathrm{C} 7-\mathrm{C} 6 \mathrm{a}$ & $131.71(17)$ \\
\hline $\mathrm{C} 7-\mathrm{C} 8-\mathrm{C} 9$ & $129.12(18)$ \\
\hline $\mathrm{O9-C9-C8}$ & $119.4(2)$ \\
\hline $\mathrm{O} 9-\mathrm{C} 9-\mathrm{C} 10$ & $121.46(19)$ \\
\hline $\mathrm{C} 8-\mathrm{C} 9-\mathrm{C} 10$ & $119.08(16)$ \\
\hline $\mathrm{C} 9-\mathrm{C} 10-\mathrm{C} 11$ & $113.17(17)$ \\
\hline $\mathrm{C} 11 \mathrm{a}-\mathrm{C} 11-\mathrm{C} 10$ & $113.11(16)$ \\
\hline $\mathrm{C} 6 \mathrm{a}-\mathrm{C} 11 \mathrm{a}-\mathrm{C} 11 \mathrm{~b}$ & $120.06(15)$ \\
\hline $\mathrm{C} 6 \mathrm{a}-\mathrm{C} 11 \mathrm{a}-\mathrm{C} 11$ & $119.97(15)$ \\
\hline $\mathrm{C} 11 \mathrm{~b}-\mathrm{C} 11 \mathrm{a}-\mathrm{C} 11$ & $119.96(15)$ \\
\hline $\mathrm{C} 5-\mathrm{C} 11 \mathrm{~b}-\mathrm{C} 1$ & $117.54(16)$ \\
\hline $\mathrm{C} 5-\mathrm{C} 11 \mathrm{~b}-\mathrm{C} 11 \mathrm{a}$ & $117.90(15)$ \\
\hline $\mathrm{C} 1-\mathrm{C} 11 \mathrm{~b}-\mathrm{C} 11 \mathrm{a}$ & $124.55(16)$ \\
\hline $\mathrm{C} 4-\mathrm{O} 4-\mathrm{C} 12$ & $117.01(16)$ \\
\hline
\end{tabular}




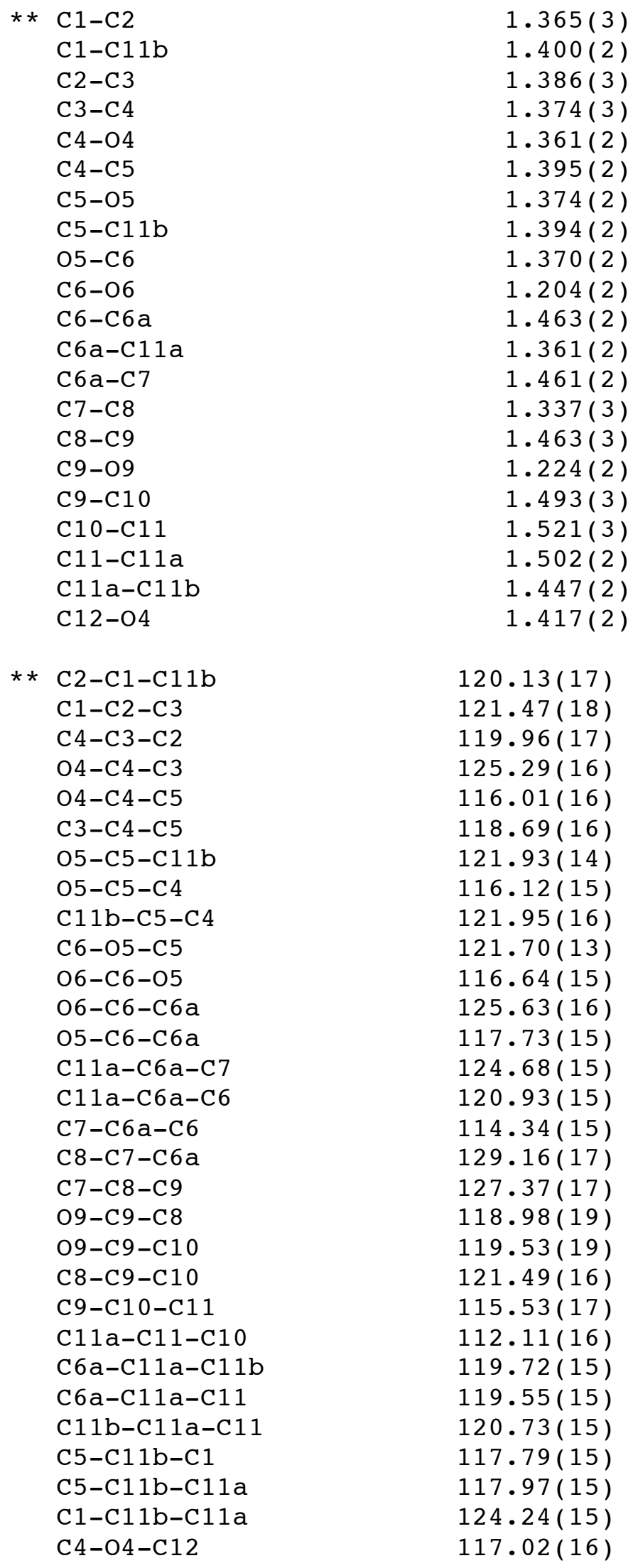


Table S6. Anisotropic displacement parameters $\left(A^{\wedge} 2 \times 10^{\wedge} 3\right)$ for compound $\mathbf{2 a}$.

The anisotropic displacement factor exponent takes the form: $-2 \mathrm{pi}^{\wedge} 2\left[\mathrm{~h} 2 \mathrm{a}{ }^{\wedge} 2 \mathrm{U} 11+\ldots+2 \mathrm{~h} \mathrm{k} a * b * \mathrm{U} 12\right.$ ]

\begin{tabular}{|c|c|c|c|c|c|c|}
\hline & & U22 & U33 & $\mathrm{U} 23$ & U13 & $\mathrm{U} 12$ \\
\hline $\mathrm{C} 1$ & $59(1)$ & $57(1)$ & $41(1)$ & $-11(1)$ & $0(1)$ & $-9(1)$ \\
\hline $\mathrm{C} 2$ & $71(1)$ & $58(1)$ & $46(1)$ & $-2(1)$ & $1(1)$ & $-18(1)$ \\
\hline C3 & $68(1)$ & $44(1)$ & $53(1)$ & $-3(1)$ & $-12(1)$ & $-13(1)$ \\
\hline $\mathrm{C} 4$ & $57(1)$ & $43(1)$ & $44(1)$ & $-12(1)$ & $-13(1)$ & $-5(1)$ \\
\hline C5 & $43(1)$ & $42(1)$ & $35(1)$ & $-7(1)$ & $-5(1)$ & $-5(1)$ \\
\hline 05 & $56(1)$ & $40(1)$ & $38(1)$ & $-12(1)$ & $0(1)$ & $-5(1)$ \\
\hline $\mathrm{C} 6$ & $46(1)$ & $40(1)$ & $34(1)$ & $-7(1)$ & $-4(1)$ & $-2(1)$ \\
\hline $\mathrm{C} 6 \mathrm{a}$ & $43(1)$ & $40(1)$ & $37(1)$ & $-11(1)$ & $-7(1)$ & $0(1)$ \\
\hline $\mathrm{C} 7$ & $61(1)$ & $44(1)$ & $39(1)$ & $-9(1)$ & $-3(1)$ & $-2(1)$ \\
\hline C8 & $74(1)$ & $43(1)$ & $54(1)$ & $-15(1)$ & $-3(1)$ & $-5(1)$ \\
\hline $\mathrm{C} 9$ & $68(1)$ & $54(1)$ & $60(1)$ & $-30(1)$ & $-10(1)$ & $0(1)$ \\
\hline $\mathrm{C} 10$ & $83(2)$ & $56(1)$ & $43(1)$ & $-23(1)$ & $-14(1)$ & $7(1)$ \\
\hline $\mathrm{C} 11$ & $64(1)$ & $50(1)$ & $43(1)$ & $-16(1)$ & $4(1)$ & $0(1)$ \\
\hline $\mathrm{C} 11 \mathrm{a}$ & $42(1)$ & $45(1)$ & $36(1)$ & $-12(1)$ & $-7(1)$ & $1(1)$ \\
\hline $\mathrm{C} 11 \mathrm{~b}$ & $43(1)$ & $44(1)$ & $36(1)$ & $-8(1)$ & $-6(1)$ & $-2(1)$ \\
\hline $\mathrm{C} 12$ & 145 ( 2) & $44(1)$ & $68(1)$ & $-21(1)$ & $-15(2)$ & $-18(1)$ \\
\hline 04 & $91(1)$ & $41(1)$ & $54(1)$ & $-17(1)$ & $-7(1)$ & $-10(1)$ \\
\hline 06 & $70(1)$ & $48(1)$ & $40(1)$ & $-10(1)$ & $7(1)$ & $-4(1)$ \\
\hline 09 & $134(2)$ & $68(1)$ & $81(1)$ & $-44(1)$ & $-11(1)$ & $-15(1)$ \\
\hline $\mathrm{C} 1$ & $67(1)$ & $46(1)$ & $39(1)$ & $-5(1)$ & $-2(1)$ & $-6(1)$ \\
\hline $\mathrm{C} 2$ & $82(2)$ & $58(1)$ & $38(1)$ & $-12(1)$ & $-5(1)$ & $-6(1)$ \\
\hline C3 & $69(1)$ & $53(1)$ & $52(1)$ & $-23(1)$ & $-12(1)$ & $0(1)$ \\
\hline $\mathrm{C} 4$ & $53(1)$ & $40(1)$ & $48(1)$ & $-12(1)$ & $-6(1)$ & $-2(1)$ \\
\hline $\mathrm{C} 5$ & $47(1)$ & $38(1)$ & $36(1)$ & $-8(1)$ & $-3(1)$ & $-1(1)$ \\
\hline 05 & $68(1)$ & $38(1)$ & $39(1)$ & $-7(1)$ & $2(1)$ & $-11(1)$ \\
\hline $\mathrm{C} 6$ & $58(1)$ & $41(1)$ & $39(1)$ & $-10(1)$ & $1(1)$ & $-6(1)$ \\
\hline $\mathrm{C} 6 \mathrm{a}$ & $44(1)$ & $36(1)$ & $40(1)$ & $-8(1)$ & $-3(1)$ & $-2(1)$ \\
\hline C7 & $57(1)$ & $48(1)$ & $40(1)$ & $-11(1)$ & $-4(1)$ & $-5(1)$ \\
\hline $\mathrm{C} 8$ & $57(1)$ & $50(1)$ & $56(1)$ & $-23(1)$ & $-4(1)$ & $-8(1)$ \\
\hline $\mathrm{C} 9$ & $50(1)$ & $37(1)$ & $70(1)$ & $-18(1)$ & $-1(1)$ & $-7(1)$ \\
\hline $\mathrm{C} 10$ & $73(1)$ & $36(1)$ & $61(1)$ & $-5(1)$ & $-14(1)$ & $-2(1)$ \\
\hline $\mathrm{C} 11$ & $60(1)$ & $39(1)$ & $44(1)$ & $-7(1)$ & $3(1)$ & $-11(1)$ \\
\hline $\mathrm{C} 11 \mathrm{a}$ & $40(1)$ & $35(1)$ & $41(1)$ & $-6(1)$ & $-2(1)$ & $0(1)$ \\
\hline $\mathrm{C} 11 \mathrm{~b}$ & $43(1)$ & $37(1)$ & $38(1)$ & $-6(1)$ & $-3(1)$ & $1(1)$ \\
\hline $\mathrm{C} 12$ & $68(1)$ & 49 (1) & $90(2)$ & $-25(1)$ & $-25(1)$ & $-6(1)$ \\
\hline 04 & $88(1)$ & $42(1)$ & 59 (1) & $-16(1)$ & $0(1)$ & $-18(1)$ \\
\hline 06 & $112(1)$ & $57(1)$ & $37(1)$ & $-8(1)$ & $10(1)$ & $-26(1)$ \\
\hline 09 & $101(1)$ & $46(1)$ & $97(1)$ & $-24(1)$ & $-2(1)$ & $11(1)$ \\
\hline
\end{tabular}


Theoretical data for compound 1 :

Final Energy in Hartrees: HF $=-879.7282735$ (B3LYP / 6-31++G(D,P))

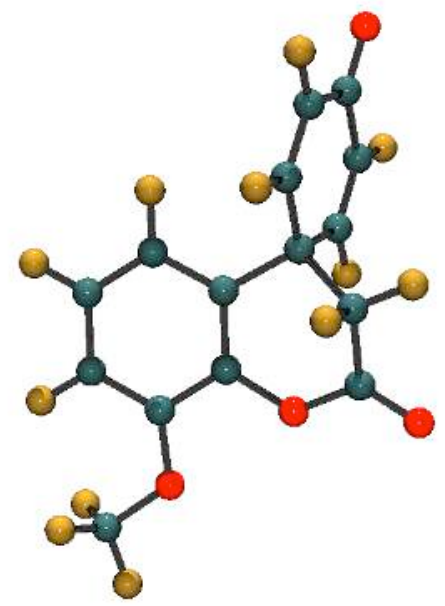

Standard orientation:

\begin{tabular}{|c|c|c|c|c|c|}
\hline \multirow{3}{*}{$\begin{array}{l}\text { Center } \\
\text { Number }\end{array}$} & \multirow{2}{*}{$\begin{array}{l}\text { Atomic } \\
\text { Number }\end{array}$} & \multirow{2}{*}{$\begin{array}{c}\text { Atomic } \\
\text { Type }\end{array}$} & \multicolumn{3}{|c|}{ Coordinates (Angstroms) } \\
\hline & & & $\mathrm{X}$ & Y & Z \\
\hline & & & & -- & -- \\
\hline 1 & 6 & 0 & 1.430375 & -2.624924 & .213216 \\
\hline 2 & 6 & 0 & 2.621041 & -1.922539 & -.002833 \\
\hline 3 & 6 & 0 & 2.603370 & -.527822 & -.102583 \\
\hline 4 & 6 & 0 & 1.368559 & .143881 & .022208 \\
\hline 5 & 6 & 0 & .180569 & -.551790 & .249198 \\
\hline 6 & 6 & 0 & .219787 & -1.951149 & .338540 \\
\hline 7 & 8 & 0 & 3.690478 & .256180 & -.315312 \\
\hline 8 & 6 & 0 & 4.962127 & -.369795 & -.457047 \\
\hline 9 & 8 & 0 & 1.413634 & 1.520834 & -.149536 \\
\hline 10 & 6 & 0 & .385244 & 2.322836 & .266576 \\
\hline 11 & 6 & 0 & -.746564 & 1.629288 & .991570 \\
\hline 12 & 6 & 0 & -1.122870 & .252859 & .360784 \\
\hline 13 & 6 & 0 & -2.109260 & -.417821 & 1.284057 \\
\hline 14 & 6 & 0 & -3.357675 & -.758168 & .928875 \\
\hline 15 & 6 & 0 & -3.870456 & -.529416 & -.441128 \\
\hline 16 & 6 & 0 & -2.933292 & .107363 & -1.390807 \\
\hline 17 & 6 & 0 & -1.690638 & .463430 & -1.028670 \\
\hline 18 & 8 & 0 & -5.011154 & -.852488 & -.767131 \\
\hline 19 & 8 & 0 & .446034 & 3.507930 & .056338 \\
\hline 20 & 1 & 0 & 5.670075 & .442406 & -.622930 \\
\hline 21 & 1 & 0 & 4.977208 & -1.049835 & -1.317395 \\
\hline 22 & 1 & 0 & 5.239930 & -.917561 & .451778 \\
\hline 23 & 1 & 0 & -3.304543 & .271909 & -2.398013 \\
\hline 24 & 1 & 0 & -4.046438 & -1.221414 & 1.629455 \\
\hline 25 & 1 & 0 & -1.025817 & .928860 & -1.754349 \\
\hline 26 & 1 & 0 & -1.600472 & 2.307732 & 1.011579 \\
\hline 27 & 1 & 0 & -.417967 & 1.462243 & 2.026169 \\
\hline 28 & 1 & 0 & -1.756578 & -.606753 & 2.296725 \\
\hline 29 & 1 & 0 & 1.457016 & -3.707770 & .283683 \\
\hline 30 & 1 & 0 & -.700312 & -2.502051 & .501309 \\
\hline 31 & 1 & 0 & 3.554074 & -2.464804 & -.094619 \\
\hline
\end{tabular}

\begin{tabular}{lrr} 
& & \multicolumn{1}{c}{1} \\
& & \multicolumn{1}{c}{ A } \\
Frequencies -- & 37.9740 \\
Red. masses -- & 5.8775 \\
Frc consts -- & .0050 \\
IR Inten -- & 1.4632
\end{tabular}

2
A
43.9304
6.0358
.0069
1.7113

3

A

80.4251

4.2839

.0163

4.0625 
Theoretical data for compound 10 :

Final Energy in Hartrees: HF $=-879.1713081(B 3 L Y P / 6-31++G(D, P))$

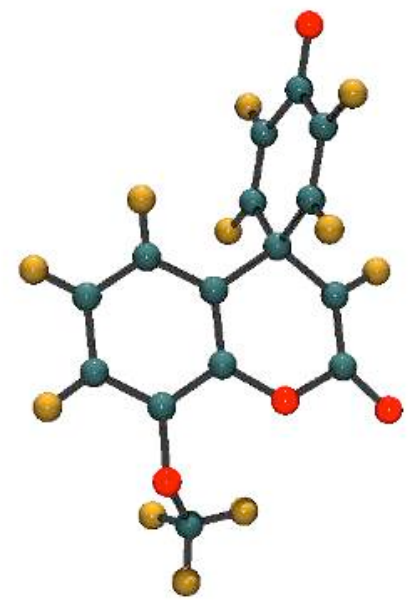

Standard orientation:

\begin{tabular}{|c|c|c|c|c|c|}
\hline \multirow{2}{*}{$\begin{array}{l}\text { Center } \\
\text { Number }\end{array}$} & \multirow{2}{*}{$\begin{array}{l}\text { Atomic } \\
\text { Number }\end{array}$} & \multirow{2}{*}{$\begin{array}{c}\text { Atomic } \\
\text { Type }\end{array}$} & \multicolumn{3}{|c|}{ Coordinates (Angstroms) } \\
\hline & & & $\mathrm{X}$ & Y & Z \\
\hline 1 & 6 & 0 & -1.099823 & -2.852971 & .067652 \\
\hline 2 & 6 & 0 & -2.382061 & -2.323520 & -.112456 \\
\hline 3 & 6 & 0 & -2.568667 & -.946705 & -.215622 \\
\hline 4 & 6 & 0 & -1.456732 & -.068011 & -.152804 \\
\hline 5 & 6 & 0 & -.171113 & -.599612 & .052513 \\
\hline 6 & 6 & 0 & -.009651 & -1.988789 & .155230 \\
\hline 7 & 8 & 0 & -1.706282 & 1.247676 & -.317863 \\
\hline 8 & 6 & 0 & -.685634 & 2.260225 & .026098 \\
\hline 9 & 6 & 0 & .584949 & 1.782350 & .281556 \\
\hline 10 & 6 & 0 & 1.040592 & .337881 & .110827 \\
\hline 11 & 6 & 0 & 1.818158 & .255868 & -1.185026 \\
\hline 12 & 6 & 0 & 3.149086 & .036962 & -1.268887 \\
\hline 13 & 6 & 0 & 3.956172 & -.240459 & -.072257 \\
\hline 14 & 6 & 0 & 3.235488 & -.250753 & 1.217840 \\
\hline 15 & 6 & 0 & 1.910831 & -.017958 & 1.292528 \\
\hline 16 & 8 & 0 & 5.175445 & -.458782 & -.133048 \\
\hline 17 & 8 & 0 & -1.154866 & 3.403836 & .040157 \\
\hline 18 & 8 & 0 & -3.848313 & -.491805 & -.457807 \\
\hline 19 & 6 & 0 & -4.385441 & .456529 & .474592 \\
\hline 20 & 1 & 0 & -5.418225 & .626898 & .159525 \\
\hline 21 & 1 & 0 & -3.824605 & 1.393258 & .457413 \\
\hline 22 & 1 & 0 & -4.381607 & .035402 & 1.489925 \\
\hline 23 & 1 & 0 & 3.837077 & -.447814 & 2.101758 \\
\hline 24 & 1 & 0 & 3.680910 & .063099 & -2.216596 \\
\hline 25 & 1 & 0 & 1.399192 & -.019641 & 2.252713 \\
\hline 26 & 1 & 0 & 1.352664 & 2.517073 & .492073 \\
\hline 27 & 1 & 0 & 1.233079 & .457160 & -2.079765 \\
\hline 28 & 1 & 0 & -.957141 & -3.927409 & .143763 \\
\hline 29 & 1 & 0 & .991046 & -2.388123 & .297472 \\
\hline 30 & 1 & 0 & -3.257177 & -2.963526 & -.180502 \\
\hline
\end{tabular}

\begin{tabular}{|c|c|c|c|c|}
\hline & & 1 & 2 & 3 \\
\hline & & A & A & A \\
\hline Frequencies & -- & 23.6524 & 50.0833 & 77.0913 \\
\hline Red. masses & -- & 5.1137 & 8.2316 & 3.8149 \\
\hline Frc consts & -- & .0017 & .0122 & .0134 \\
\hline IR Inten & -- & .1974 & 2.6776 & 3.0598 \\
\hline
\end{tabular}


Theoretical data for transition state TS1:

Final Energy in Hartrees: HF $=-879.1565668(B 3 L Y P / 6-31++G(D, P))$

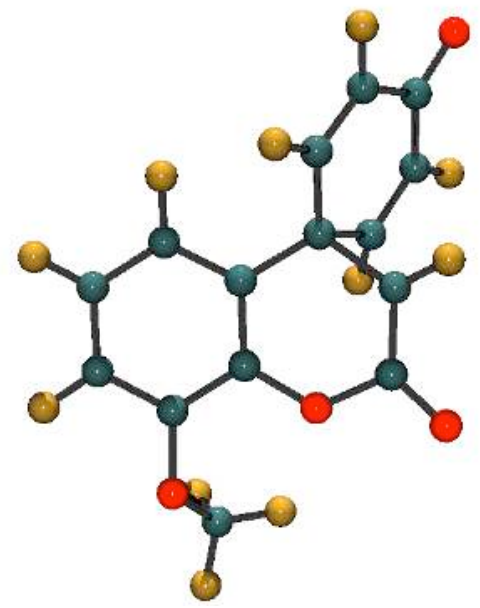

Standard orientation:

\begin{tabular}{|c|c|c|c|c|c|}
\hline \multirow{2}{*}{$\begin{array}{l}\text { Center } \\
\text { Number }\end{array}$} & \multirow{2}{*}{$\begin{array}{l}\text { Atomic } \\
\text { Number }\end{array}$} & \multirow{2}{*}{$\begin{array}{c}\text { Atomic } \\
\text { Type }\end{array}$} & \multicolumn{3}{|c|}{ Coordinates (Angstroms) } \\
\hline & & & $\mathrm{x}$ & $\mathrm{Y}$ & Z \\
\hline 1 & 6 & 0 & 1.762037 & 2.812218 & -.089311 \\
\hline 2 & 6 & 0 & 2.882876 & 1.989731 & .035655 \\
\hline 3 & 6 & 0 & 2.743113 & .600062 & .021253 \\
\hline 4 & 6 & 0 & 1.462768 & .027827 & -.127712 \\
\hline 5 & 6 & 0 & .328060 & .850609 & -.234145 \\
\hline 6 & 6 & 0 & .494473 & 2.241037 & -.217040 \\
\hline 7 & 8 & 0 & 1.393892 & -1.341116 & -.153544 \\
\hline 8 & 6 & 0 & .242067 & -2.020849 & -.673900 \\
\hline 9 & 6 & 0 & -.966746 & -1.285037 & -.689980 \\
\hline 10 & 6 & 0 & -1.027367 & .208614 & -.334931 \\
\hline 11 & 6 & 0 & -2.091101 & .992244 & -1.026739 \\
\hline 12 & 6 & 0 & -3.378996 & .932594 & -.641946 \\
\hline 13 & 6 & 0 & -3.872450 & .133695 & .524643 \\
\hline 14 & 6 & 0 & -2.875262 & -.564137 & 1.249143 \\
\hline 15 & 6 & 0 & -1.507795 & -.551482 & .858863 \\
\hline 16 & 8 & 0 & -5.107060 & .159937 & .789692 \\
\hline 17 & 8 & 0 & .439835 & -3.184879 & -1.001810 \\
\hline 18 & 8 & 0 & 3.892712 & -.159296 & .074873 \\
\hline 19 & 6 & 0 & 4.001168 & -1.094708 & 1.154339 \\
\hline 20 & 1 & 0 & 5.003775 & -1.522315 & 1.076342 \\
\hline 21 & 1 & 0 & 3.251179 & -1.884599 & 1.074182 \\
\hline 22 & 1 & 0 & 3.900847 & -.578728 & 2.119345 \\
\hline 23 & 1 & 0 & -3.175830 & -1.148391 & 2.113975 \\
\hline 24 & 1 & 0 & -4.145830 & 1.488939 & -1.177672 \\
\hline 25 & 1 & 0 & -.750657 & -.833117 & 1.584782 \\
\hline 26 & 1 & 0 & -1.804899 & -1.721033 & -1.214428 \\
\hline 27 & 1 & 0 & -1.786970 & 1.601024 & -1.877644 \\
\hline 28 & 1 & 0 & 1.874710 & 3.892732 & -.072820 \\
\hline 29 & 1 & 0 & -.385208 & 2.873298 & -.287786 \\
\hline 30 & 1 & 0 & 3.882775 & 2.400510 & .138889 \\
\hline
\end{tabular}

\begin{tabular}{|c|c|c|c|}
\hline & 1 & 2 & 3 \\
\hline & A & A & A \\
\hline Frequencies & $--\quad-306.1658$ & 47.2981 & 70.6809 \\
\hline Red. masses & 10.1525 & 5.5042 & 7.5343 \\
\hline Frc consts & .5607 & .0073 & .0222 \\
\hline IR Inten & 679.7455 & 1.4875 & 5.1084 \\
\hline
\end{tabular}


Theoretical data for compound 11 :

Final Energy in Hartrees: HF $=-879.1575149$ (B3LYP / 6-31++G(D,P))

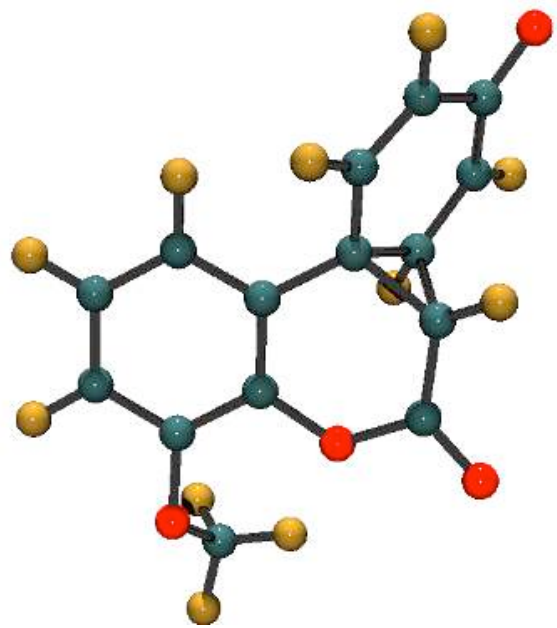

Standard orientation:

\begin{tabular}{|c|c|c|c|c|c|}
\hline \multirow{2}{*}{$\begin{array}{l}\text { Center } \\
\text { Number }\end{array}$} & \multirow{2}{*}{$\begin{array}{l}\text { Atomic } \\
\text { Number }\end{array}$} & \multirow{2}{*}{$\begin{array}{c}\text { Atomic } \\
\text { Type }\end{array}$} & \multicolumn{3}{|c|}{ Coordinates (Angstroms) } \\
\hline & & & $\mathrm{x}$ & Y & Z \\
\hline 1 & 6 & 0 & 1.830040 & 2.797463 & -.071724 \\
\hline 2 & 6 & 0 & 2.932000 & 1.949851 & .050594 \\
\hline 3 & 6 & 0 & 2.757611 & .563768 & .022794 \\
\hline 4 & 6 & 0 & 1.465679 & .028664 & -.139005 \\
\hline 5 & 6 & 0 & .346388 & .872614 & -.239086 \\
\hline 6 & 6 & 0 & .549154 & 2.259542 & -.207675 \\
\hline 7 & 8 & 0 & 1.371328 & -1.345710 & -.197197 \\
\hline 8 & 6 & 0 & .208904 & -1.988554 & -.679070 \\
\hline 9 & 6 & 0 & -1.022991 & -1.249849 & -.603895 \\
\hline 10 & 6 & 0 & -1.017239 & .273691 & -.341464 \\
\hline 11 & 6 & 0 & -2.088583 & 1.067370 & -.991238 \\
\hline 12 & 6 & 0 & -3.378785 & .956625 & -.615073 \\
\hline 13 & 6 & 0 & -3.869451 & .118146 & .524238 \\
\hline 14 & 6 & 0 & -2.872787 & -.587109 & 1.222433 \\
\hline 15 & 6 & 0 & -1.482653 & -.602843 & .805574 \\
\hline 16 & 8 & 0 & -5.110250 & .150989 & .795114 \\
\hline 17 & 8 & 0 & .360958 & -3.135659 & -1.066143 \\
\hline 18 & 8 & 0 & 3.884996 & -.228376 & .074596 \\
\hline 19 & 6 & 0 & 3.972050 & -1.151124 & 1.166408 \\
\hline 20 & 1 & 0 & 4.958058 & -1.615034 & 1.085956 \\
\hline 21 & 1 & 0 & 3.195582 & -1.917220 & 1.104707 \\
\hline 22 & 1 & 0 & 3.897988 & -.618852 & 2.124710 \\
\hline 23 & 1 & 0 & -3.152015 & -1.154191 & 2.106032 \\
\hline 24 & 1 & 0 & -4.151057 & 1.527222 & -1.128143 \\
\hline 25 & 1 & 0 & -.737753 & -.805479 & 1.573245 \\
\hline 26 & 1 & 0 & -1.840061 & -1.655617 & -1.186229 \\
\hline 27 & 1 & 0 & -1.795939 & 1.735808 & -1.800652 \\
\hline 28 & 1 & 0 & 1.967395 & 3.874928 & -.044685 \\
\hline 29 & 1 & 0 & -.315072 & 2.912970 & -.270753 \\
\hline 30 & 1 & 0 & 3.940597 & 2.335985 & .161980 \\
\hline
\end{tabular}

\begin{tabular}{|c|c|c|c|c|}
\hline & & 1 & 2 & 3 \\
\hline & & A & A & A \\
\hline Frequencies & -- & 48.2311 & 70.1956 & 82.0859 \\
\hline Red. masses & -- & 5.6904 & 7.1232 & 2.1130 \\
\hline Frc consts & -- & .0078 & .0207 & .0084 \\
\hline IR Inten & -- & 1.5936 & 4.5749 & 2.4441 \\
\hline
\end{tabular}


Theoretical data for transition state TS2 :

Final Energy in Hartrees: HF $=-879.1498774(B 3 L Y P / 6-31++G(D, P))$

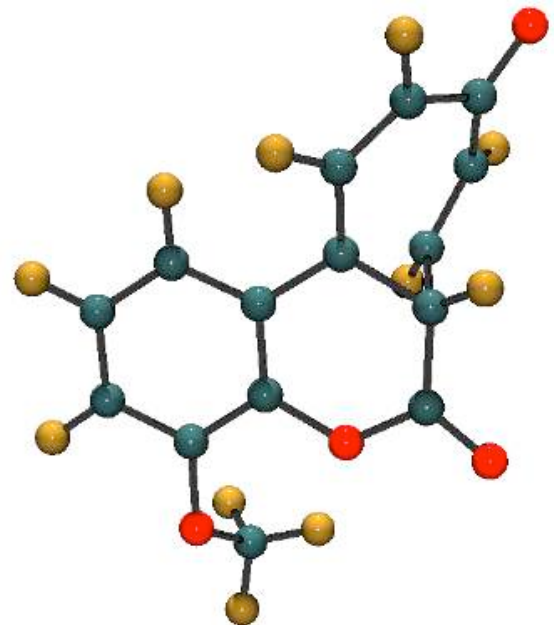

Standard orientation:

\begin{tabular}{|c|c|c|c|c|c|}
\hline \multirow{2}{*}{$\begin{array}{l}\text { Center } \\
\text { Number }\end{array}$} & \multirow{2}{*}{$\begin{array}{l}\text { Atomic } \\
\text { Number }\end{array}$} & \multirow{2}{*}{$\begin{array}{c}\text { Atomic } \\
\text { Type }\end{array}$} & \multicolumn{3}{|c|}{ Coordinates (Angstroms) } \\
\hline & & & $\mathrm{X}$ & Y & Z \\
\hline & & & & --------1 & --------- \\
\hline 1 & 6 & 0 & 1.991332 & 2.759143 & .028772 \\
\hline 2 & 6 & 0 & 3.054286 & 1.856076 & .107168 \\
\hline 3 & 6 & 0 & 2.801733 & .482672 & .004455 \\
\hline 4 & 6 & 0 & 1.490466 & .032580 & -.194103 \\
\hline 5 & 6 & 0 & .400029 & .925571 & -.257191 \\
\hline 6 & 6 & 0 & .684811 & 2.301430 & -.133744 \\
\hline 7 & 8 & 0 & 1.332975 & -1.343693 & -.345028 \\
\hline 8 & 6 & 0 & .117357 & -1.919713 & -.663535 \\
\hline 9 & 6 & 0 & -1.102501 & -1.100030 & -.511240 \\
\hline 10 & 6 & 0 & -.956278 & .404500 & -.408237 \\
\hline 11 & 6 & 0 & -2.049201 & 1.221933 & -.891606 \\
\hline 12 & 6 & 0 & -3.364550 & .969723 & -.625544 \\
\hline 13 & 6 & 0 & -3.886536 & .085363 & .441455 \\
\hline 14 & 6 & 0 & -2.893935 & -.532625 & 1.256949 \\
\hline 15 & 6 & 0 & -1.537099 & -.701408 & .874813 \\
\hline 16 & 8 & 0 & -5.131875 & .082607 & .687464 \\
\hline 17 & 8 & 0 & .137008 & -3.076820 & -1.028650 \\
\hline 18 & 8 & 0 & 3.880871 & -.379087 & .021835 \\
\hline 19 & 6 & 0 & 3.923296 & -1.316361 & 1.101854 \\
\hline 20 & 1 & 0 & 4.873879 & -1.846231 & 1.002370 \\
\hline 21 & 1 & 0 & 3.097461 & -2.030844 & 1.045665 \\
\hline 22 & 1 & 0 & 3.898385 & -.792178 & 2.067086 \\
\hline 23 & 1 & 0 & -3.164653 & -.766447 & 2.283432 \\
\hline 24 & 1 & 0 & -4.125681 & 1.592774 & -1.092193 \\
\hline 25 & 1 & 0 & -.798758 & -.880922 & 1.655018 \\
\hline 26 & 1 & 0 & -1.905465 & -1.460601 & -1.150695 \\
\hline 27 & 1 & 0 & -1.785898 & 2.093272 & -1.492571 \\
\hline 28 & 1 & 0 & 2.181389 & 3.825697 & .117190 \\
\hline 29 & 1 & 0 & -.141325 & 3.004531 & -.147085 \\
\hline 30 & 1 & 0 & 4.079582 & 2.183773 & .245220 \\
\hline
\end{tabular}

\begin{tabular}{lrrrr} 
& & 1 & \multicolumn{1}{c}{2} & \multicolumn{1}{c}{3} \\
& & \multicolumn{1}{c}{ A } & \multicolumn{1}{c}{ A } & A \\
Frequencies -- & -490.6418 & 45.5429 & 69.6040 \\
Red. masses -- & 5.3992 & 5.8733 & 3.8492 \\
Frc consts & -- & .7658 & .0072 & .0110 \\
IR Inten & -- & 192.1547 & 1.7354 & 5.4452
\end{tabular}


Theoretical data for compound $12 \mathrm{c}$ :

Final Energy in Hartrees: HF $=-879.1830086(B 3 L Y P / 6-31++G(D, P))$

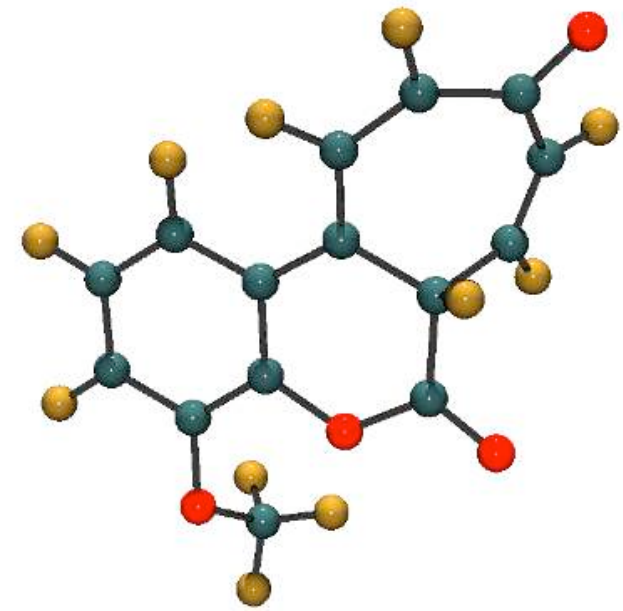

Standard orientation:

\begin{tabular}{|c|c|c|c|c|c|}
\hline \multirow{2}{*}{$\begin{array}{l}\text { Center } \\
\text { Number }\end{array}$} & \multirow{2}{*}{$\begin{array}{l}\text { Atomic } \\
\text { Number }\end{array}$} & \multirow{2}{*}{$\begin{array}{c}\text { Atomic } \\
\text { Type }\end{array}$} & \multicolumn{3}{|c|}{ Coordinates (Angstroms) } \\
\hline & & & $\mathrm{x}$ & Y & Z \\
\hline 1 & 6 & 0 & 2.335577 & 2.677858 & .251889 \\
\hline 2 & 6 & 0 & 3.320110 & 1.687280 & .145429 \\
\hline 3 & 6 & 0 & 2.924765 & .363419 & -.074728 \\
\hline 4 & 6 & 0 & 1.566548 & .056256 & -.205162 \\
\hline 5 & 6 & 0 & .546117 & 1.031948 & -.100438 \\
\hline 6 & 6 & 0 & .985961 & 2.359914 & .153063 \\
\hline 7 & 8 & 0 & 1.270963 & -1.277981 & -.477378 \\
\hline 8 & 6 & 0 & .000414 & -1.775410 & -.507299 \\
\hline 9 & 6 & 0 & -1.175356 & -.831733 & -.346487 \\
\hline 10 & 6 & 0 & -.827778 & .640135 & -.267227 \\
\hline 11 & 6 & 0 & -1.875458 & 1.538939 & -.453509 \\
\hline 12 & 6 & 0 & -3.256571 & 1.288041 & -.465608 \\
\hline 13 & 6 & 0 & -3.993232 & .222438 & .160908 \\
\hline 14 & 6 & 0 & -3.278597 & -.771295 & 1.011439 \\
\hline 15 & 6 & 0 & -2.035032 & -1.250326 & .833021 \\
\hline 16 & 8 & 0 & -5.252903 & .172737 & .137627 \\
\hline 17 & 8 & 0 & -.122864 & -2.970504 & -.679653 \\
\hline 18 & 8 & 0 & 3.909685 & -.595509 & -.232150 \\
\hline 19 & 6 & 0 & 3.951887 & -1.618693 & .765245 \\
\hline 20 & 1 & 0 & 2.629018 & 3.708089 & .439438 \\
\hline 21 & 1 & 0 & 4.378441 & 1.909370 & .232365 \\
\hline 22 & 1 & 0 & .243072 & 3.138436 & .288234 \\
\hline 23 & 1 & 0 & -1.791455 & -.990033 & -1.251905 \\
\hline 24 & 1 & 0 & -1.593787 & 2.572195 & -.664226 \\
\hline 25 & 1 & 0 & -3.899675 & 2.072967 & -.860299 \\
\hline 26 & 1 & 0 & -3.874991 & -1.140038 & 1.844359 \\
\hline 27 & 1 & 0 & -1.618152 & -1.963356 & 1.543020 \\
\hline 28 & 1 & 0 & 4.830967 & -2.226972 & .536677 \\
\hline 29 & 1 & 0 & 3.055942 & -2.245485 & .736111 \\
\hline 30 & 1 & 0 & 4.065440 & -1.177740 & 1.765442 \\
\hline
\end{tabular}

\begin{tabular}{|c|c|c|c|c|}
\hline & & 1 & 2 & 3 \\
\hline & & A & A & A \\
\hline Frequencies & -- & 35.6304 & 62.8939 & 78.0753 \\
\hline Red. masses & -- & 6.7930 & 3.5666 & 6.1076 \\
\hline Frc consts & -- & .0051 & .0083 & .0219 \\
\hline IR Inten & -- & .2839 & .3609 & 3.1001 \\
\hline
\end{tabular}


Theoretical data for compound 2a :

Final Energy in Hartrees: HF $=-879.7472803$ (B3LYP / 6-31++G(D,P))

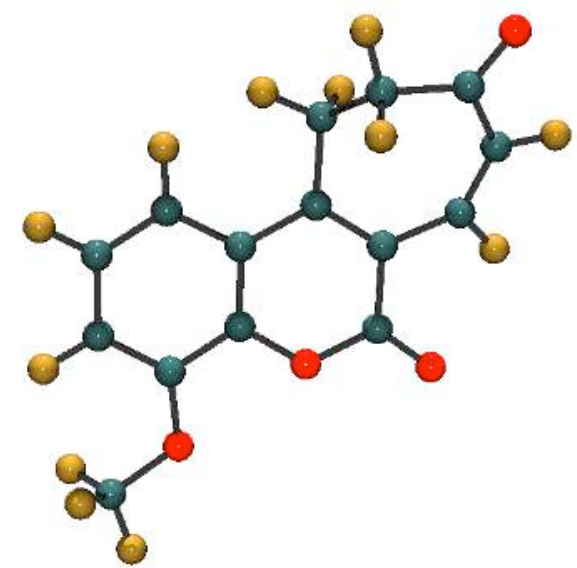

Standard orientation:

\begin{tabular}{|c|c|c|c|c|c|}
\hline \multirow{2}{*}{$\begin{array}{l}\text { Center } \\
\text { Number }\end{array}$} & \multirow{2}{*}{$\begin{array}{l}\text { Atomic } \\
\text { Number }\end{array}$} & \multirow{2}{*}{$\begin{array}{c}\text { Atomic } \\
\text { Type }\end{array}$} & \multicolumn{3}{|c|}{ Coordinates (Angstroms) } \\
\hline & & & $\mathrm{X}$ & Y & Z \\
\hline 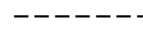 & - & & --------1 & --------- & -------1 \\
\hline 1 & 6 & 0 & 2.349150 & -2.507020 & -.140323 \\
\hline 2 & 6 & 0 & 3.310763 & -1.496038 & .021122 \\
\hline 3 & 6 & 0 & 2.917250 & -.160087 & .074401 \\
\hline 4 & 6 & 0 & 1.540855 & .145310 & -.038901 \\
\hline 5 & 6 & 0 & .566571 & -.854500 & -.204577 \\
\hline 6 & 6 & 0 & 1.004075 & -2.202037 & -.250928 \\
\hline 7 & 8 & 0 & 3.747390 & .900227 & .228288 \\
\hline 8 & 6 & 0 & 5.145697 & .654887 & .347793 \\
\hline 9 & 8 & 0 & 1.219489 & 1.464892 & .017180 \\
\hline 10 & 6 & 0 & -.079672 & 1.920359 & -.070011 \\
\hline 11 & 6 & 0 & -1.139629 & .904328 & -.225502 \\
\hline 12 & 6 & 0 & -.823046 & -.433999 & -.310222 \\
\hline 13 & 8 & 0 & -.255921 & 3.118293 & -.015285 \\
\hline 14 & 6 & 0 & -2.474584 & 1.483322 & -.363343 \\
\hline 15 & 6 & 0 & -3.709570 & .954388 & -.180142 \\
\hline 16 & 6 & 0 & -4.085459 & -.382297 & .318918 \\
\hline 17 & 6 & 0 & -3.010718 & -1.432930 & .550618 \\
\hline 18 & 6 & 0 & -1.918926 & -1.445294 & -.537072 \\
\hline 19 & 8 & 0 & -5.262011 & -.636784 & .557367 \\
\hline 20 & 1 & 0 & 5.605419 & 1.636875 & .459401 \\
\hline 21 & 1 & 0 & 5.541581 & .165065 & -.550198 \\
\hline 22 & 1 & 0 & 5.368002 & .043875 & 1.231139 \\
\hline 23 & 1 & 0 & -3.519087 & -2.399541 & .599453 \\
\hline 24 & 1 & 0 & -2.563546 & -1.255830 & 1.538860 \\
\hline 25 & 1 & 0 & -4.566968 & 1.602253 & -.342670 \\
\hline 26 & 1 & 0 & 2.671876 & -3.542588 & -.176273 \\
\hline 27 & 1 & 0 & .290442 & -3.006791 & -.368260 \\
\hline 28 & 1 & 0 & 4.357227 & -1.762248 & .105044 \\
\hline 29 & 1 & 0 & -2.441191 & 2.538150 & -.623357 \\
\hline 30 & 1 & 0 & -1.508287 & -2.450502 & -.613372 \\
\hline 31 & 1 & 0 & -2.383598 & -1.232090 & -1.511147 \\
\hline
\end{tabular}

\begin{tabular}{|c|c|c|c|c|}
\hline & & 1 & 2 & 3 \\
\hline & & A & A & A \\
\hline Frequencies & -- & 31.7646 & 53.9631 & 71.6721 \\
\hline Red. masses & -- & 6.0848 & 3.7000 & 6.2170 \\
\hline Frc consts & -- & .0036 & .0063 & .0188 \\
\hline IR Inten & -- & .5194 & 1.4801 & 10.6039 \\
\hline
\end{tabular}


Theoretical data for transition state TS4n :

Final Energy in Hartrees: $\mathrm{HF}=-879.662717$ (B3LYP/6-31++G(D,P))

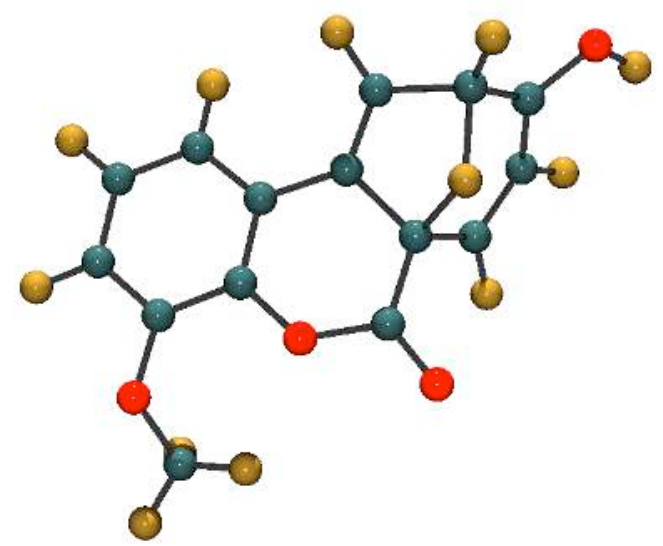

Standard orientation:

\begin{tabular}{|c|c|c|c|c|c|}
\hline \multirow{2}{*}{$\begin{array}{l}\text { Center } \\
\text { Number }\end{array}$} & \multirow{2}{*}{$\begin{array}{l}\text { Atomic } \\
\text { Number }\end{array}$} & \multirow{2}{*}{$\begin{array}{c}\text { Atomic } \\
\text { Type }\end{array}$} & \multicolumn{3}{|c|}{ Coordinates (Angstroms) } \\
\hline & & & $\mathrm{X}$ & Y & Z \\
\hline----1 & & & 9019877 & --------1 & -------- \\
\hline 1 & 6 & 0 & 2.424677 & 2.655365 & .403496 \\
\hline 2 & 6 & 0 & 3.365309 & 1.636139 & .230276 \\
\hline 3 & 6 & 0 & 2.958324 & .333511 & -.071641 \\
\hline 4 & 6 & 0 & 1.583637 & .072055 & -.209371 \\
\hline 5 & 6 & 0 & .627554 & 1.086422 & -.036927 \\
\hline 6 & 6 & 0 & 1.064765 & 2.383114 & .280003 \\
\hline 7 & 8 & 0 & 3.925313 & -.606824 & -.304929 \\
\hline 8 & 6 & 0 & 3.920715 & -1.789692 & .511612 \\
\hline 9 & 8 & 0 & 1.226437 & -1.217005 & -.577833 \\
\hline 10 & 6 & 0 & -.045409 & -1.718288 & -.387352 \\
\hline 11 & 6 & 0 & -1.134013 & -.736911 & -.117287 \\
\hline 12 & 6 & 0 & -.765191 & .714782 & -.272374 \\
\hline 13 & 8 & 0 & -.198716 & -2.916255 & -.461189 \\
\hline 14 & 6 & 0 & -1.978092 & -1.095991 & .997645 \\
\hline 15 & 6 & 0 & -3.218478 & -.519000 & 1.190716 \\
\hline 16 & 6 & 0 & -3.804525 & .229514 & .145843 \\
\hline 17 & 6 & 0 & -3.044839 & .683018 & -.964734 \\
\hline 18 & 6 & 0 & -1.796930 & 1.458880 & -.711085 \\
\hline 19 & 8 & 0 & -5.150946 & .383565 & .076332 \\
\hline 20 & 1 & 0 & 2.757488 & 3.659527 & .647334 \\
\hline 21 & 1 & 0 & 4.429509 & 1.826154 & .323039 \\
\hline 22 & 1 & 0 & .329525 & 3.166585 & .433258 \\
\hline 23 & 1 & 0 & 4.839297 & -2.321641 & .259030 \\
\hline 24 & 1 & 0 & 3.055701 & -2.420834 & .297554 \\
\hline 25 & 1 & 0 & 3.937192 & -1.518258 & 1.574473 \\
\hline 26 & 1 & 0 & -1.678539 & -1.919488 & 1.641991 \\
\hline 27 & 1 & 0 & -3.830841 & -.829895 & 2.034151 \\
\hline 28 & 1 & 0 & -3.653422 & 1.001031 & -1.812975 \\
\hline 29 & 1 & 0 & -2.200999 & -.527817 & -1.028892 \\
\hline 30 & 1 & 0 & -1.755042 & 2.523330 & -.919649 \\
\hline 31 & 1 & 0 & -5.591618 & -.144047 & .758723 \\
\hline
\end{tabular}

1

A

Frequencies -- -1503.8333

Red. masses -- 1.1994

Frc consts -- 1.5982

IR Inten -- 247.0457

\section{2}

A

43.5221

6.1536

.0069

1.7397
3

A

58.9796

2.0421

.0042

2.5080 
Theoretical data for transition state TS4a :

Final Energy in Hartrees: HF $=-879.1443616(B 3 L Y P / 6-31++G(D, P))$

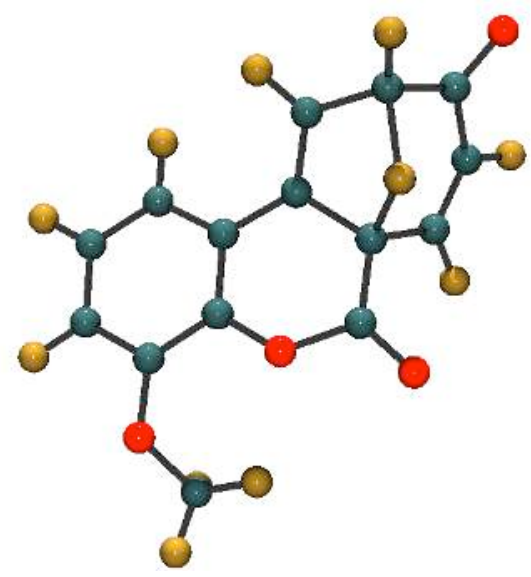

Standard orientation:

\begin{tabular}{|c|c|c|c|c|c|}
\hline \multirow{2}{*}{$\begin{array}{l}\text { Center } \\
\text { Number }\end{array}$} & \multirow{2}{*}{$\begin{array}{l}\text { Atomic } \\
\text { Number }\end{array}$} & \multirow{2}{*}{$\begin{array}{c}\text { Atomic } \\
\text { Type }\end{array}$} & \multicolumn{3}{|c|}{ Coordinates (Angstroms) } \\
\hline & & & $\mathrm{X}$ & Y & Z \\
\hline & & & & & (1) \\
\hline 1 & 6 & 0 & 2.412460 & 2.644924 & .430127 \\
\hline 2 & 6 & 0 & 3.353816 & 1.631956 & .216492 \\
\hline 3 & 6 & 0 & 2.928919 & .336883 & -.097623 \\
\hline 4 & 6 & 0 & 1.554657 & .070975 & -.209893 \\
\hline 5 & 6 & 0 & .593066 & 1.077694 & .015001 \\
\hline 6 & 6 & 0 & 1.049229 & 2.369535 & .344228 \\
\hline 7 & 8 & 0 & 1.183408 & -1.199535 & -.595416 \\
\hline 8 & 6 & 0 & -.101695 & -1.709630 & -.334994 \\
\hline 9 & 6 & 0 & -1.180581 & -.741945 & -.100597 \\
\hline 10 & 6 & 0 & -.794613 & .703235 & -.184137 \\
\hline 11 & 6 & 0 & -1.821465 & 1.471174 & -.645435 \\
\hline 12 & 6 & 0 & -3.061427 & .760480 & -.968287 \\
\hline 13 & 6 & 0 & -3.948442 & .241275 & .087218 \\
\hline 14 & 6 & 0 & -3.329051 & -.586567 & 1.137662 \\
\hline 15 & 6 & 0 & -2.095239 & -1.130402 & .998668 \\
\hline 16 & 8 & 0 & -5.191362 & .388298 & .058649 \\
\hline 17 & 8 & 0 & -.199449 & -2.923404 & -.361573 \\
\hline 18 & 8 & 0 & 3.896761 & -.610292 & -.363527 \\
\hline 19 & 6 & 0 & 3.872910 & -1.797787 & .437693 \\
\hline 20 & 1 & 0 & 4.767889 & -2.360594 & .160465 \\
\hline 21 & 1 & 0 & 2.980158 & -2.396043 & .241864 \\
\hline 22 & 1 & 0 & 3.922400 & -1.540547 & 1.504732 \\
\hline 23 & 1 & 0 & -3.983720 & -.895326 & 1.949330 \\
\hline 24 & 1 & 0 & -3.650773 & 1.196020 & -1.780067 \\
\hline 25 & 1 & 0 & -1.763393 & -1.907039 & 1.687927 \\
\hline 26 & 1 & 0 & -2.174153 & -.523676 & -1.033214 \\
\hline 27 & 1 & 0 & -1.694158 & 2.522276 & -.900780 \\
\hline 28 & 1 & 0 & 2.748341 & 3.647488 & .682622 \\
\hline 29 & 1 & 0 & .316535 & 3.147455 & .536826 \\
\hline 30 & 1 & 0 & 4.420739 & 1.818642 & .288487 \\
\hline
\end{tabular}

1

Frequencies -- -1437.1718

Red. masses -- 1.1704

Frc consts -- $\quad 1.4243$

IR Inten -- 543.4094
2

A

45.6003

6.5841

.0081

.0748

\section{3}

A

70.2999

2.5285

.0074

2.2404 
Theoretical data for transition state TS5a :

Final Energy in Hartrees: HF $=-879.1087276$ (B3LYP / 6-31++G(D,P))

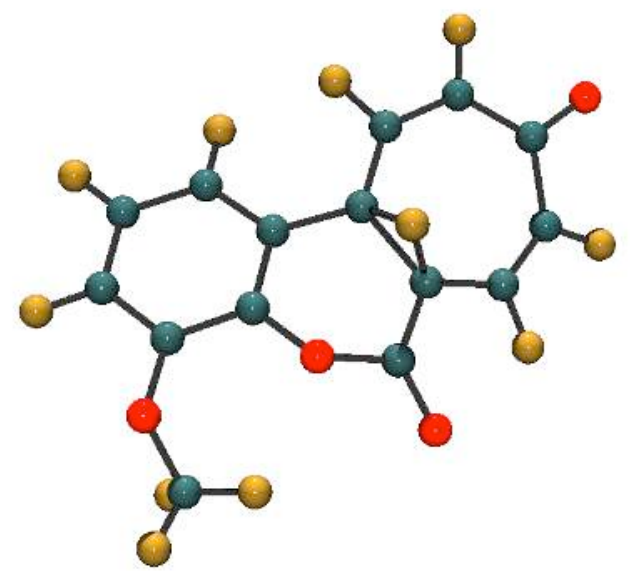

Standard orientation:

\begin{tabular}{|c|c|c|c|c|c|}
\hline \multirow{2}{*}{$\begin{array}{l}\text { Center } \\
\text { Number }\end{array}$} & \multirow{2}{*}{$\begin{array}{l}\text { Atomic } \\
\text { Number }\end{array}$} & \multirow{2}{*}{$\begin{array}{c}\text { Atomic } \\
\text { Type }\end{array}$} & \multicolumn{3}{|c|}{ Coordinates (Angstroms) } \\
\hline & & & $\mathrm{X}$ & $\mathrm{Y}$ & Z \\
\hline-1 & -1 & ------ & --------1 & -------- & --------- \\
\hline 1 & 6 & 0 & 2.271007 & 2.709654 & .412532 \\
\hline 2 & 6 & 0 & 3.280412 & 1.758013 & .255286 \\
\hline 3 & 6 & 0 & 2.938058 & .439209 & -.073108 \\
\hline 4 & 6 & 0 & 1.593226 & .103722 & -.276729 \\
\hline 5 & 6 & 0 & .557432 & 1.048560 & -.114176 \\
\hline 6 & 6 & 0 & .928901 & 2.358775 & .257300 \\
\hline 7 & 8 & 0 & 1.304502 & -1.173721 & -.725645 \\
\hline 8 & 6 & 0 & .121902 & -1.800965 & -.236434 \\
\hline 9 & 6 & 0 & -1.031494 & -.957562 & -.148758 \\
\hline 10 & 6 & 0 & -.818397 & .598188 & -.318788 \\
\hline 11 & 6 & 0 & -1.903230 & 1.513478 & -.407375 \\
\hline 12 & 6 & 0 & -3.273487 & 1.380259 & -.328964 \\
\hline 13 & 6 & 0 & -4.074749 & .252673 & .124351 \\
\hline 14 & 6 & 0 & -3.505940 & -1.062873 & .520750 \\
\hline 15 & 6 & 0 & -2.249085 & -1.546704 & .376251 \\
\hline 16 & 8 & 0 & -5.312659 & .383026 & .221195 \\
\hline 17 & 8 & 0 & .208365 & -3.003177 & -.010553 \\
\hline 18 & 8 & 0 & 3.964686 & -.461151 & -.272376 \\
\hline 19 & 6 & 0 & 3.934253 & -1.650263 & .528321 \\
\hline 20 & 1 & 0 & 4.855368 & -2.189669 & .292622 \\
\hline 21 & 1 & 0 & 3.066320 & -2.270654 & .293977 \\
\hline 22 & 1 & 0 & 3.929500 & -1.390359 & 1.595948 \\
\hline 23 & 1 & 0 & -4.261567 & -1.726661 & .932504 \\
\hline 24 & 1 & 0 & -3.873832 & 2.257354 & -.555164 \\
\hline 25 & 1 & 0 & -2.089282 & -2.579159 & .685042 \\
\hline 26 & 1 & 0 & -1.006246 & -.291395 & -1.249489 \\
\hline 27 & 1 & 0 & -1.571081 & 2.529177 & -.623978 \\
\hline 28 & 1 & 0 & 2.529493 & 3.729904 & .685401 \\
\hline 29 & 1 & 0 & .159734 & 3.102305 & .435730 \\
\hline 30 & 1 & 0 & 4.329586 & 2.004359 & .383673 \\
\hline
\end{tabular}

\section{1 \\ A}

Frequencies -- -1653.2005

Red. masses -- 1.2708

Frc consts -- $\quad 2.0463$

IR Inten -- 1805.7267

2
A
47.5290
6.4905
.0086
1.0927

3

A

56.5620

4.2436

.0080

.2551 
Theoretical data for compound $\mathbf{2 b}$ :

Final Energy in Hartrees: HF $=-879.7303913$ (B3LYP / 6-31++G(D,P))

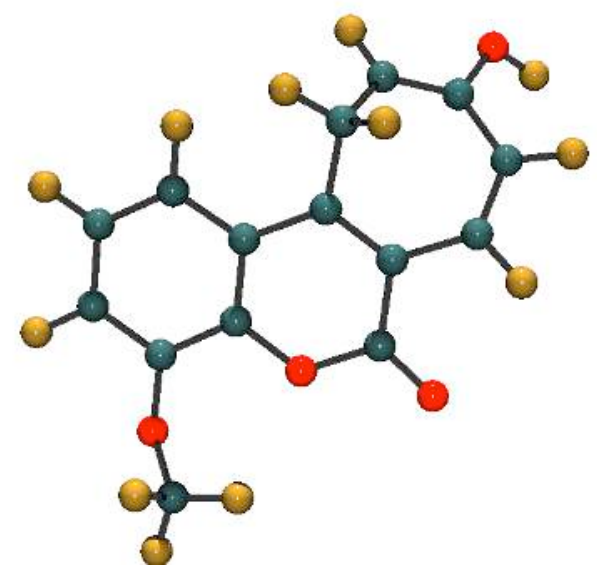

Standard orientation:

\begin{tabular}{|c|c|c|c|c|c|}
\hline \multirow{2}{*}{$\begin{array}{l}\text { Center } \\
\text { Number }\end{array}$} & \multirow{2}{*}{$\begin{array}{l}\text { Atomic } \\
\text { Number }\end{array}$} & \multirow{2}{*}{$\begin{array}{c}\text { Atomic } \\
\text { Type }\end{array}$} & \multicolumn{3}{|c|}{ Coordinates (Angstroms) } \\
\hline & & & $\mathrm{X}$ & Y & Z \\
\hline & & & & - & --- \\
\hline 1 & 6 & 0 & -2.193964 & -2.717996 & -.005408 \\
\hline 2 & 6 & 0 & -3.183343 & -1.780092 & .316443 \\
\hline 3 & 6 & 0 & -2.885688 & -.419421 & .358380 \\
\hline 4 & 6 & 0 & -1.566146 & -.008887 & .083528 \\
\hline 5 & 6 & 0 & -.559332 & -.933911 & -.259383 \\
\hline 6 & 6 & 0 & -.902507 & -2.303378 & -.299425 \\
\hline 7 & 8 & 0 & -3.861281 & .453962 & .751821 \\
\hline 8 & 6 & 0 & -4.260214 & 1.473597 & -.181669 \\
\hline 9 & 8 & 0 & -1.309616 & 1.329381 & .163424 \\
\hline 10 & 6 & 0 & -.056619 & 1.873325 & -.060454 \\
\hline 11 & 6 & 0 & 1.030405 & .932030 & -.368538 \\
\hline 12 & 6 & 0 & .769101 & -.413274 & -.534670 \\
\hline 13 & 8 & 0 & .043640 & 3.080134 & .006075 \\
\hline 14 & 6 & 0 & 2.345896 & 1.538691 & -.480753 \\
\hline 15 & 6 & 0 & 3.539090 & .966586 & -.157270 \\
\hline 16 & 6 & 0 & 3.728781 & -.381598 & .348203 \\
\hline 17 & 6 & 0 & 2.944743 & -1.431612 & .015834 \\
\hline 18 & 6 & 0 & 1.888528 & -1.292406 & -1.048564 \\
\hline 19 & 8 & 0 & 4.794868 & -.595389 & 1.197666 \\
\hline 20 & 1 & 0 & -2.441307 & -3.774498 & -.027519 \\
\hline 21 & 1 & 0 & -4.197940 & -2.086821 & .548413 \\
\hline 22 & 1 & 0 & -.147791 & -3.042299 & -.539317 \\
\hline 23 & 1 & 0 & -5.107797 & 1.978518 & .283644 \\
\hline 24 & 1 & 0 & -4.579714 & 1.018045 & -1.126881 \\
\hline 25 & 1 & 0 & -3.455128 & 2.189550 & -.360269 \\
\hline 26 & 1 & 0 & 2.343896 & 2.596619 & -.725695 \\
\hline 27 & 1 & 0 & 4.424396 & 1.601378 & -.186119 \\
\hline 28 & 1 & 0 & 3.099226 & -2.386695 & .508575 \\
\hline 29 & 1 & 0 & 2.310219 & -.812661 & -1.943087 \\
\hline 30 & 1 & 0 & 1.521640 & -2.271618 & -1.354825 \\
\hline 31 & 1 & 0 & 5.057025 & .235852 & 1.613668 \\
\hline
\end{tabular}

\begin{tabular}{|c|c|c|c|c|}
\hline & & 1 & 2 & 3 \\
\hline & & A & A & A \\
\hline Frequencies & -- & 40.4893 & 59.3426 & 72.3116 \\
\hline Red. masses & -- & 6.2660 & 3.8561 & 2.0836 \\
\hline Frc consts & -- & .0061 & .0080 & .0064 \\
\hline IR Inten & -- & .6649 & .9673 & 3.7119 \\
\hline
\end{tabular}


Theoretical data for compound $2 \mathrm{c}$ :

Final Energy in Hartrees: HF $=-879.1790705$ (B3LYP / 6-31++G(D,P))

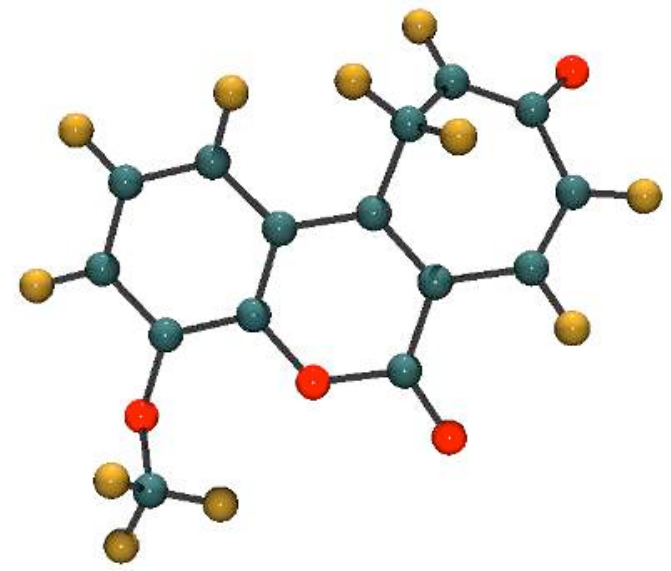

Standard orientation:

\begin{tabular}{|c|c|c|c|c|c|}
\hline \multirow{2}{*}{$\begin{array}{l}\text { Center } \\
\text { Number }\end{array}$} & \multirow{2}{*}{$\begin{array}{l}\text { Atomic } \\
\text { Number }\end{array}$} & \multirow{2}{*}{$\begin{array}{c}\text { Atomic } \\
\text { Type }\end{array}$} & \multicolumn{3}{|c|}{ Coordinates (Angstroms) } \\
\hline & & & $\mathrm{x}$ & $\mathrm{Y}$ & Z \\
\hline 1 & 6 & 0 & 2.091416 & -2.728786 & -.000267 \\
\hline 2 & 6 & 0 & 3.101241 & -1.811241 & -.318604 \\
\hline 3 & 6 & 0 & 2.817364 & -.446930 & -.358420 \\
\hline 4 & 6 & 0 & 1.508025 & -.006515 & -.085982 \\
\hline 5 & 6 & 0 & .483096 & -.912349 & .260714 \\
\hline 6 & 6 & 0 & .807200 & -2.287085 & .294118 \\
\hline 7 & 8 & 0 & 3.820644 & .416465 & -.742965 \\
\hline 8 & 6 & 0 & 4.204153 & 1.421210 & .203778 \\
\hline 9 & 8 & 0 & 1.279156 & 1.335755 & -.157830 \\
\hline 10 & 6 & 0 & .011239 & 1.902344 & .055428 \\
\hline 11 & 6 & 0 & -1.074543 & .991141 & .370540 \\
\hline 12 & 6 & 0 & -.828761 & -.368908 & .569537 \\
\hline 13 & 8 & 0 & -.034073 & 3.119157 & -.021290 \\
\hline 14 & 6 & 0 & -2.405141 & 1.566952 & .409224 \\
\hline 15 & 6 & 0 & -3.566346 & .937933 & .055781 \\
\hline 16 & 6 & 0 & -3.758193 & -.441988 & -.466559 \\
\hline 17 & 6 & 0 & -2.894069 & -1.443923 & .017289 \\
\hline 18 & 6 & 0 & -1.931538 & -1.205736 & 1.148695 \\
\hline 19 & 8 & 0 & -4.693550 & -.627021 & -1.312390 \\
\hline 20 & 1 & 0 & 2.314592 & -3.792003 & .015484 \\
\hline 21 & 1 & 0 & 4.111739 & -2.132980 & -.550448 \\
\hline 22 & 1 & 0 & .030166 & -3.007145 & .522049 \\
\hline 23 & 1 & 0 & 5.065622 & 1.929692 & -.235713 \\
\hline 24 & 1 & 0 & 4.502029 & .957717 & 1.154353 \\
\hline 25 & 1 & 0 & 3.398073 & 2.138483 & .375701 \\
\hline 26 & 1 & 0 & -2.438202 & 2.639878 & .582453 \\
\hline 27 & 1 & 0 & -4.458515 & 1.557923 & -.030460 \\
\hline 28 & 1 & 0 & -2.956021 & -2.434598 & -.427673 \\
\hline 29 & 1 & 0 & -2.387801 & -.659269 & 1.989299 \\
\hline 30 & 1 & 0 & -1.549957 & -2.149261 & 1.549116 \\
\hline
\end{tabular}

\begin{tabular}{|c|c|c|c|c|}
\hline & & 1 & 2 & 3 \\
\hline & & A & A & A \\
\hline Frequencies & -- & 41.5043 & 60.1134 & 82.1901 \\
\hline Red. masses & -- & 6.9013 & 4.6347 & 2.1725 \\
\hline Frc consts & -- & .0070 & .0099 & .0086 \\
\hline IR Inten & -- & 1.8849 & 2.3228 & 4.8168 \\
\hline
\end{tabular}


Theoretical data for compound 13a :

Final Energy in Hartrees: HF $=-879.7447082(B 3 L Y P / 6-31++G(D, P))$

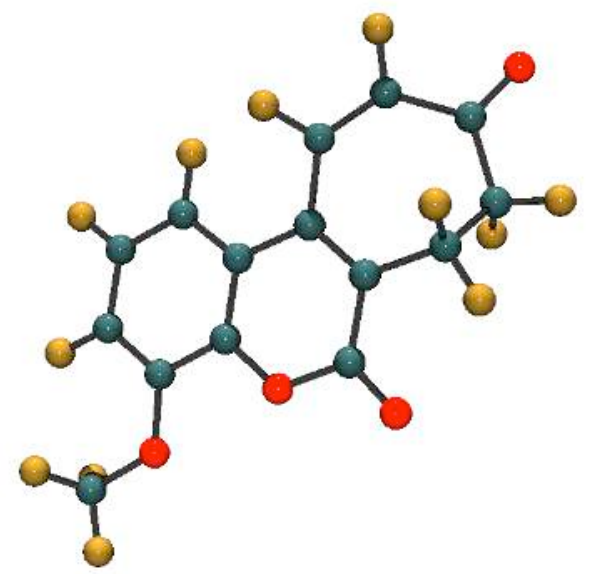

Standard orientation:

\begin{tabular}{|c|c|c|c|c|c|}
\hline \multirow{2}{*}{$\begin{array}{l}\text { Center } \\
\text { Number }\end{array}$} & \multirow{2}{*}{$\begin{array}{l}\text { Atomic } \\
\text { Number }\end{array}$} & \multirow{2}{*}{$\begin{array}{c}\text { Atomic } \\
\text { Type }\end{array}$} & \multicolumn{3}{|c|}{ Coordinates (Angstroms) } \\
\hline & & & $\mathrm{X}$ & $\mathrm{Y}$ & Z \\
\hline & 6 & 0 & $\begin{array}{lll}-2 & 313421\end{array}$ & -2530857 & 059514 \\
\hline$\frac{1}{2}$ & 6 & 0 & $\begin{array}{l}-2.313421 \\
-3285576\end{array}$ & $\begin{array}{l}-2.030851 \\
-1.522069\end{array}$ & .059514 \\
\hline 2 & 0 & 0 & -3.285316 & $-1.32 \angle 069$ & $\cdot 13 \perp 148$ \\
\hline 3 & 6 & 0 & -2.907587 & -.181313 & .096624 \\
\hline 4 & 6 & 0 & -1.536649 & .129297 & -.059679 \\
\hline 5 & 6 & 0 & -.559558 & -.868676 & -.174515 \\
\hline 6 & 6 & 0 & -.973105 & -2.219105 & -.097839 \\
\hline 7 & 8 & 0 & -3.748446 & .878694 & .185674 \\
\hline 8 & 6 & 0 & -5.141028 & .626915 & .347323 \\
\hline 9 & 8 & 0 & -1.221952 & 1.454816 & -.086491 \\
\hline 10 & 6 & 0 & .075777 & 1.909311 & -.185967 \\
\hline 11 & 6 & 0 & 1.136599 & .899564 & -.326087 \\
\hline 12 & 6 & 0 & .831284 & -.437298 & -.341383 \\
\hline 13 & 8 & 0 & .253130 & 3.110256 & -.167064 \\
\hline 14 & 6 & 0 & 2.538257 & 1.432610 & -.462934 \\
\hline 15 & 6 & 0 & 3.495093 & .914964 & .624067 \\
\hline 16 & 6 & 0 & 4.013841 & -.489613 & .374859 \\
\hline 17 & 6 & 0 & 3.171645 & -1.490677 & -.331164 \\
\hline 18 & 6 & 0 & 1.846527 & -1.469861 & -.598601 \\
\hline 19 & 8 & 0 & 5.136678 & -.820998 & .737536 \\
\hline 20 & 1 & 0 & -5.611636 & 1.609062 & .393986 \\
\hline 21 & 1 & 0 & -5.341184 & .080480 & 1.277109 \\
\hline 22 & 1 & 0 & -5.545671 & .067202 & -.504807 \\
\hline 23 & 1 & 0 & 2.997377 & .923972 & 1.604415 \\
\hline 24 & 1 & 0 & 4.372134 & 1.562471 & .714992 \\
\hline 25 & 1 & 0 & 3.728810 & -2.385153 & -.599243 \\
\hline 26 & 1 & 0 & -2.622066 & -3.569685 & .119166 \\
\hline 27 & 1 & 0 & -.243862 & -3.018370 & -.141877 \\
\hline 28 & 1 & 0 & -4.327137 & -1.792752 & .272819 \\
\hline 29 & 1 & 0 & 2.490689 & 2.521517 & -.420468 \\
\hline 30 & 1 & 0 & 2.937119 & 1.167176 & -1.453275 \\
\hline 31 & 1 & 0 & 1.457562 & -2.367225 & -1.072250 \\
\hline
\end{tabular}

\begin{tabular}{|c|c|c|c|c|}
\hline & & 1 & 2 & 3 \\
\hline & & A & A & A \\
\hline Frequencies & -- & 31.8613 & 57.6338 & 67.2632 \\
\hline Red. masses & -- & 6.5382 & 4.7245 & 4.5207 \\
\hline Frc consts & -- & .0039 & .0092 & .0121 \\
\hline IR Inten & -- & 1.2865 & 10.3222 & .5703 \\
\hline
\end{tabular}


Theoretical data for compound $\mathbf{1 3 b}$ :

Final Energy in Hartrees: HF $=-879.7297326(B 3 L Y P / 6-31++G(D, P))$

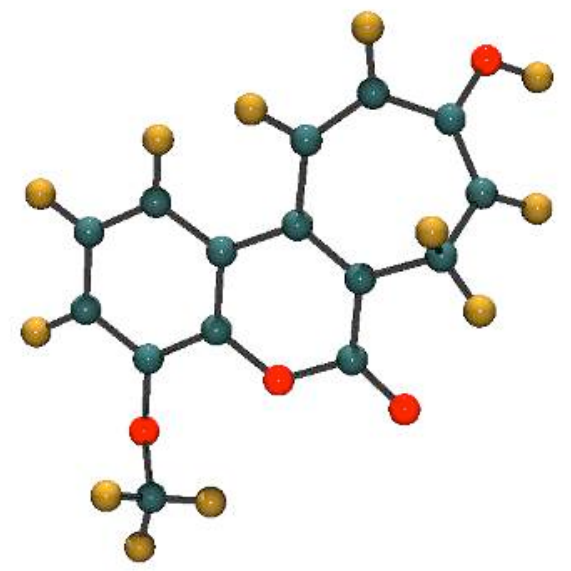

Standard orientation:

\begin{tabular}{|c|c|c|c|c|c|}
\hline \multirow{2}{*}{$\begin{array}{l}\text { Center } \\
\text { Number }\end{array}$} & \multirow{2}{*}{$\begin{array}{l}\text { Atomic } \\
\text { Number }\end{array}$} & \multirow{2}{*}{$\begin{array}{c}\text { Atomic } \\
\text { Type }\end{array}$} & \multicolumn{3}{|c|}{ Coordinates (Angstroms) } \\
\hline & & & $\mathrm{X}$ & $\mathrm{Y}$ & Z \\
\hline & & & & -7 & --1 \\
\hline 1 & 6 & 0 & 2.248134 & 2.721570 & .047005 \\
\hline 2 & 6 & 0 & 3.232827 & 1.763404 & .315882 \\
\hline 3 & 6 & 0 & 2.913285 & .407731 & .338178 \\
\hline 4 & 6 & 0 & 1.580361 & .023099 & .087420 \\
\hline 5 & 6 & 0 & .582571 & .967972 & -.215226 \\
\hline 6 & 6 & 0 & .941194 & 2.332397 & -.216162 \\
\hline 7 & 8 & 0 & 3.883699 & -.488664 & .692121 \\
\hline 8 & 6 & 0 & 4.229686 & -1.508309 & -.261214 \\
\hline 9 & 8 & 0 & 1.300316 & -1.311232 & .179952 \\
\hline 10 & 6 & 0 & .034690 & -1.828936 & -.031864 \\
\hline 11 & 6 & 0 & -1.013467 & -.883574 & -.417937 \\
\hline 12 & 6 & 0 & -.769066 & .467197 & -.482597 \\
\hline 13 & 8 & 0 & -.104522 & -3.029056 & .095036 \\
\hline 14 & 6 & 0 & -2.361594 & -1.459645 & -.780408 \\
\hline 15 & 6 & 0 & -3.402190 & -1.027401 & .221718 \\
\hline 16 & 6 & 0 & -3.760053 & .270682 & .336952 \\
\hline 17 & 6 & 0 & -3.130832 & 1.352801 & -.403503 \\
\hline 18 & 6 & 0 & -1.831047 & 1.423356 & -.792789 \\
\hline 19 & 8 & 0 & -4.779326 & .723650 & 1.144955 \\
\hline 20 & 1 & 0 & 2.508494 & 3.775256 & .046406 \\
\hline 21 & 1 & 0 & 4.257577 & 2.049665 & .528494 \\
\hline 22 & 1 & 0 & .190204 & 3.089319 & -.405542 \\
\hline 23 & 1 & 0 & 5.084895 & -2.031332 & .168999 \\
\hline 24 & 1 & 0 & 4.521986 & -1.052304 & -1.215060 \\
\hline 25 & 1 & 0 & 3.406041 & -2.208979 & -.414248 \\
\hline 26 & 1 & 0 & -2.288795 & -2.546981 & -.805958 \\
\hline 27 & 1 & 0 & -2.638084 & -1.113113 & -1.786898 \\
\hline 28 & 1 & 0 & -3.883656 & -1.783489 & .839478 \\
\hline 29 & 1 & 0 & -3.764543 & 2.218699 & -.582316 \\
\hline 30 & 1 & 0 & -1.526733 & 2.338920 & -1.290520 \\
\hline 31 & 1 & 0 & -5.235721 & -.027320 & 1.547929 \\
\hline
\end{tabular}

\begin{tabular}{|c|c|c|c|c|}
\hline & & 1 & 2 & 3 \\
\hline & & A & A & A \\
\hline Frequencies & -- & 40.4855 & 56.5587 & 67.6228 \\
\hline Red. masses & -- & 5.8898 & 3.3867 & 2.1990 \\
\hline Frc consts & -- & .0057 & .0064 & .0059 \\
\hline IR Inten & -- & .6914 & 1.3699 & 3.4663 \\
\hline
\end{tabular}


Theoretical data for compound $13 \mathrm{c}$ :

Final Energy in Hartrees: HF $=-879.1767698$ (B3LYP / 6-31++G(D,P))

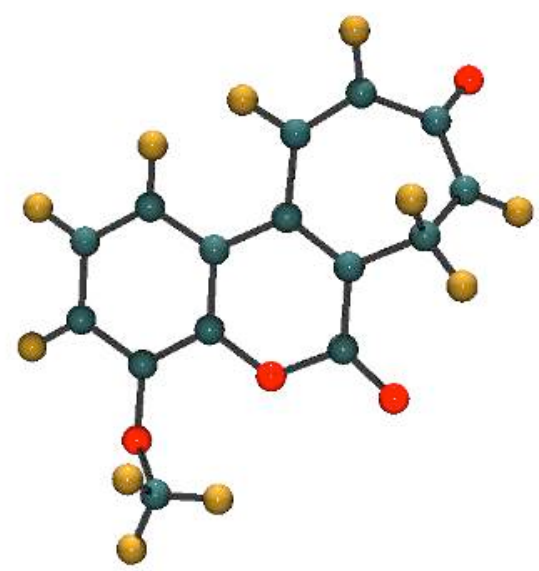

Standard orientation:

\begin{tabular}{|c|c|c|c|c|c|}
\hline \multirow{2}{*}{$\begin{array}{l}\text { Center } \\
\text { Number }\end{array}$} & \multirow{2}{*}{$\begin{array}{l}\text { Atomic } \\
\text { Number }\end{array}$} & \multirow{2}{*}{$\begin{array}{c}\text { Atomic } \\
\text { Type }\end{array}$} & \multicolumn{3}{|c|}{ Coordinates (Angstroms) } \\
\hline & & & $\mathrm{x}$ & $\mathrm{Y}$ & Z \\
\hline 1 & 6 & 0 & 2.258180 & 2.707007 & 0.020072 \\
\hline 2 & 6 & 0 & 3.231437 & 1.737316 & 0.291916 \\
\hline 3 & 6 & 0 & 2.876416 & 0.390133 & 0.334611 \\
\hline 4 & 6 & 0 & 1.537128 & 0.021285 & 0.103438 \\
\hline 5 & 6 & 0 & 0.549392 & 0.977626 & -0.210645 \\
\hline 6 & 6 & 0 & 0.941767 & 2.334915 & -0.226086 \\
\hline 7 & 8 & 0 & 3.844411 & -0.527165 & 0.682609 \\
\hline 8 & 6 & 0 & 4.130179 & -1.556921 & -0.271412 \\
\hline 9 & 8 & 0 & 1.237509 & -1.305211 & 0.212909 \\
\hline 10 & 6 & 0 & -0.049744 & -1.810920 & -0.021620 \\
\hline 11 & 6 & 0 & -1.071330 & -0.860311 & -0.421099 \\
\hline 12 & 6 & 0 & -0.806211 & 0.502121 & -0.485060 \\
\hline 13 & 8 & 0 & -0.165325 & -3.019487 & 0.091486 \\
\hline 14 & 6 & 0 & -2.416753 & -1.398903 & -0.834223 \\
\hline 15 & 6 & 0 & -3.422328 & -1.028501 & 0.223719 \\
\hline 16 & 6 & 0 & -3.838275 & 0.292863 & 0.449848 \\
\hline 17 & 6 & 0 & -3.170167 & 1.354633 & -0.350169 \\
\hline 18 & 6 & 0 & -1.866125 & 1.455685 & -0.753797 \\
\hline 19 & 8 & 0 & -4.755895 & 0.667790 & 1.255531 \\
\hline 20 & 1 & 0 & 2.533361 & 3.758052 & 0.006535 \\
\hline 21 & 1 & 0 & 4.264092 & 2.004643 & 0.492800 \\
\hline 22 & 1 & 0 & 0.198601 & 3.099770 & -0.415266 \\
\hline 23 & 1 & 0 & 4.977987 & -2.112324 & 0.136529 \\
\hline 24 & 1 & 0 & 4.415113 & -1.116069 & -1.236542 \\
\hline 25 & 1 & 0 & 3.277618 & -2.226949 & -0.404985 \\
\hline 26 & 1 & 0 & -2.350537 & -2.484499 & -0.932205 \\
\hline 27 & 1 & 0 & -2.669477 & -0.984370 & -1.825194 \\
\hline 28 & 1 & 0 & -3.873543 & -1.816649 & 0.822042 \\
\hline 29 & 1 & 0 & -3.793879 & 2.238733 & -0.485798 \\
\hline 30 & 1 & 0 & -1.566325 & 2.404077 & -1.195161 \\
\hline
\end{tabular}

\begin{tabular}{|c|c|c|c|c|}
\hline & & 1 & 2 & 3 \\
\hline & & A & A & A \\
\hline Frequencies & -- & 40.4683 & 54.8517 & 75.6483 \\
\hline Red. masses & -- & 6.5766 & 4.4953 & 2.0564 \\
\hline Frc consts & -- & .0063 & .0080 & .0069 \\
\hline IR Inten & -- & 1.6994 & .4552 & 3.7086 \\
\hline
\end{tabular}


Theoretical data for compound 12a :

Final Energy in Hartrees: HF $=-879.7161544(B 3 L Y P / 6-31++G(D, P))$

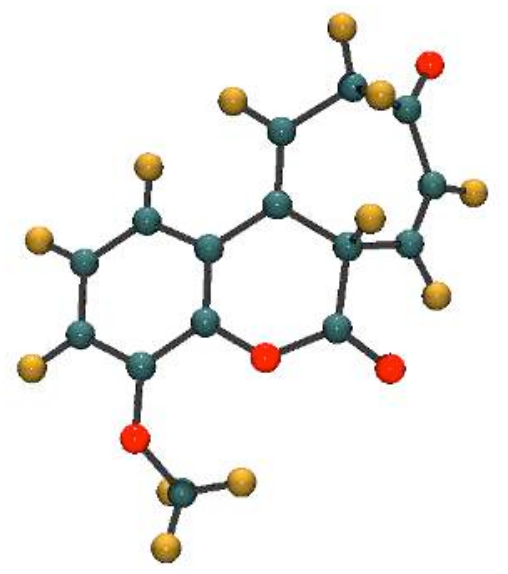

Standard orientation:

\begin{tabular}{|c|c|c|c|c|c|}
\hline \multirow{3}{*}{$\begin{array}{l}\text { Center } \\
\text { Number }\end{array}$} & \multirow{2}{*}{$\begin{array}{l}\text { Atomic } \\
\text { Number }\end{array}$} & \multirow{2}{*}{$\begin{array}{c}\text { Atomic } \\
\text { Type }\end{array}$} & \multicolumn{3}{|c|}{ Coordinates (Angstroms) } \\
\hline & & & $\mathrm{X}$ & Y & Z \\
\hline & & & & 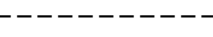 & ---- \\
\hline 1 & 6 & 0 & 2.157522 & 2.747102 & .304289 \\
\hline 2 & 6 & 0 & 3.192667 & 1.809808 & .232235 \\
\hline 3 & 6 & 0 & 2.906108 & .469345 & -.022237 \\
\hline 4 & 6 & 0 & 1.566299 & .088695 & -.221535 \\
\hline 5 & 6 & 0 & .513486 & 1.012111 & -.170525 \\
\hline 6 & 6 & 0 & .838087 & 2.352963 & .115694 \\
\hline 7 & 8 & 0 & 3.940772 & -.416923 & -.154972 \\
\hline 8 & 6 & 0 & 4.049180 & -1.450060 & .838862 \\
\hline 9 & 8 & 0 & 1.367028 & -1.258275 & -.497477 \\
\hline 10 & 6 & 0 & .140743 & -1.842796 & -.471446 \\
\hline 11 & 6 & 0 & -1.103106 & -.958751 & -.455747 \\
\hline 12 & 6 & 0 & -.859600 & .549213 & -.431108 \\
\hline 13 & 8 & 0 & .073917 & -3.047539 & -.503295 \\
\hline 14 & 6 & 0 & -2.057941 & -1.461385 & .617351 \\
\hline 15 & 6 & 0 & -3.242224 & -.925692 & .962084 \\
\hline 16 & 6 & 0 & -3.917847 & .243304 & .349868 \\
\hline 17 & 6 & 0 & -3.307689 & .880705 & -.900324 \\
\hline 18 & 6 & 0 & -1.899120 & 1.368021 & -.672412 \\
\hline 19 & 8 & 0 & -4.964042 & .666374 & .822475 \\
\hline 20 & 1 & 0 & -1.569801 & -1.198179 & -1.427171 \\
\hline 21 & 1 & 0 & 4.967708 & -1.989312 & .603310 \\
\hline 22 & 1 & 0 & 3.199584 & -2.136317 & .795824 \\
\hline 23 & 1 & 0 & 4.129897 & -1.008294 & 1.839577 \\
\hline 24 & 1 & 0 & -3.808846 & -1.380906 & 1.770604 \\
\hline 25 & 1 & 0 & 4.229957 & 2.095412 & .371394 \\
\hline 26 & 1 & 0 & -3.965978 & 1.695855 & -1.204408 \\
\hline 27 & 1 & 0 & -3.325635 & .122272 & -1.700434 \\
\hline 28 & 1 & 0 & -1.752655 & 2.443225 & -.684839 \\
\hline 29 & 1 & 0 & 2.384498 & 3.786451 & .519588 \\
\hline 30 & 1 & 0 & .045851 & 3.088026 & .199879 \\
\hline 31 & 1 & 0 & -1.735367 & -2.362810 & 1.132520 \\
\hline
\end{tabular}

\begin{tabular}{|c|c|c|c|c|}
\hline & & 1 & 2 & 3 \\
\hline & & A & A & A \\
\hline Frequencies & -- & 34.8250 & 54.7312 & 61.2133 \\
\hline Red. masses & -- & 6.6370 & 3.9926 & 5.0008 \\
\hline Frc consts & -- & .0047 & .0070 & .0110 \\
\hline IR Inten & -- & .5916 & 3.8859 & 3.0258 \\
\hline
\end{tabular}


Theoretical data for compound $\mathbf{1 2 b}$ :

Final Energy in Hartrees: HF $=-879.7154875(B 3 L Y P / 6-31++G(D, P))$

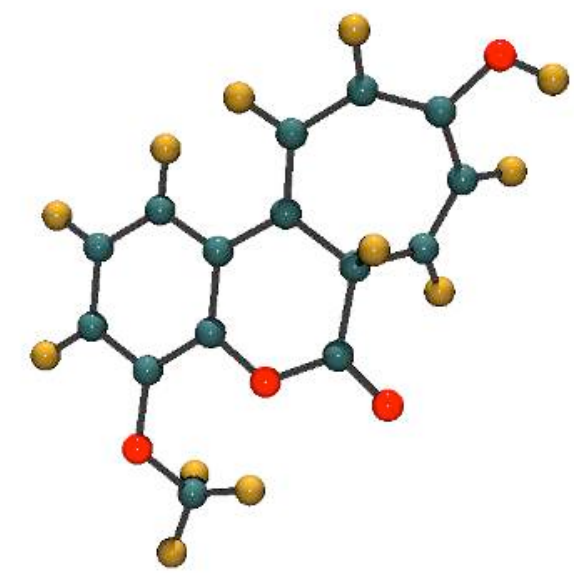

Standard orientation:

\begin{tabular}{|c|c|c|c|c|c|}
\hline \multirow{2}{*}{$\begin{array}{l}\text { Center } \\
\text { Number }\end{array}$} & \multirow{2}{*}{$\begin{array}{l}\text { Atomic } \\
\text { Number }\end{array}$} & \multirow{2}{*}{$\begin{array}{c}\text { Atomic } \\
\text { Type }\end{array}$} & \multicolumn{3}{|c|}{ Coordinates (Angstroms) } \\
\hline & & & $\mathrm{X}$ & Y & Z \\
\hline 1 & 6 & 0 & 2.355393 & 2.675332 & .304424 \\
\hline 2 & 6 & 0 & 3.330982 & 1.682857 & .169081 \\
\hline 3 & 6 & 0 & 2.957362 & .361762 & -.080352 \\
\hline 4 & 6 & 0 & 1.591801 & .055642 & -.214580 \\
\hline 5 & 6 & 0 & .594053 & 1.037413 & -.093902 \\
\hline 6 & 6 & 0 & 1.007427 & 2.355002 & .190512 \\
\hline 7 & 8 & 0 & 3.938588 & -.574831 & -.272336 \\
\hline 8 & 6 & 0 & 4.024765 & -1.639471 & .688602 \\
\hline 9 & 8 & 0 & 1.302453 & -1.272899 & -.495412 \\
\hline 10 & 6 & 0 & .036340 & -1.780125 & -.479620 \\
\hline 11 & 6 & 0 & -1.136400 & -.828857 & -.325685 \\
\hline 12 & 6 & 0 & -.803824 & .649941 & -.288121 \\
\hline 13 & 8 & 0 & -.104210 & -2.972799 & -.602175 \\
\hline 14 & 6 & 0 & -1.948359 & -1.164472 & .903202 \\
\hline 15 & 6 & 0 & -3.214621 & -.715932 & 1.041459 \\
\hline 16 & 6 & 0 & -3.856810 & .209998 & .132292 \\
\hline 17 & 6 & 0 & -3.224435 & 1.220778 & -.547366 \\
\hline 18 & 6 & 0 & -1.824927 & 1.533098 & -.500044 \\
\hline 19 & 8 & 0 & -5.230750 & .197458 & .072648 \\
\hline 20 & 1 & 0 & 2.651848 & 3.697912 & .516212 \\
\hline 21 & 1 & 0 & 4.388609 & 1.908175 & .256270 \\
\hline 22 & 1 & 0 & .258887 & 3.126335 & .333113 \\
\hline 23 & 1 & 0 & 4.911672 & -2.212559 & .414156 \\
\hline 24 & 1 & 0 & 3.143847 & -2.285175 & .649820 \\
\hline 25 & 1 & 0 & 4.151239 & -1.231337 & 1.699081 \\
\hline 26 & 1 & 0 & -1.775744 & -1.015828 & -1.202860 \\
\hline 27 & 1 & 0 & -1.496203 & -1.770462 & 1.683527 \\
\hline 28 & 1 & 0 & -3.791788 & -1.025441 & 1.912186 \\
\hline 29 & 1 & 0 & -3.877518 & 1.925239 & -1.056915 \\
\hline 30 & 1 & 0 & -1.575588 & 2.577962 & -.667630 \\
\hline 31 & 1 & 0 & -5.570374 & -.628041 & .441821 \\
\hline
\end{tabular}

\begin{tabular}{|c|c|c|c|c|}
\hline & & 1 & 2 & 3 \\
\hline & & A & A & A \\
\hline Frequencies & -- & 35.8372 & 58.2511 & 74.5111 \\
\hline Red. masses & -- & 6.3175 & 2.8679 & 3.0436 \\
\hline Frc consts & -- & .0048 & .0057 & .0100 \\
\hline IR Inten & -- & 1.1746 & .9009 & 2.3515 \\
\hline
\end{tabular}


Theoretical data for compound 14a :

Final Energy in Hartrees: HF $=-879.7186584(B 3 L Y P / 6-31++G(D, P))$

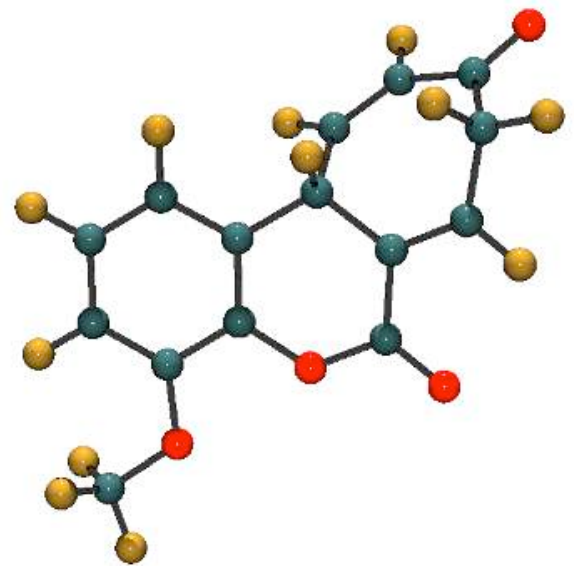

Standard orientation:

\begin{tabular}{|c|c|c|c|c|c|}
\hline \multirow{2}{*}{$\begin{array}{l}\text { Center } \\
\text { Number }\end{array}$} & \multirow{2}{*}{$\begin{array}{l}\text { Atomic } \\
\text { Number }\end{array}$} & \multirow{2}{*}{$\begin{array}{l}\text { Atomic } \\
\text { Type }\end{array}$} & \multicolumn{3}{|c|}{ Coordinates (Angstroms) } \\
\hline & & & $\mathrm{X}$ & $Y$ & Z \\
\hline & & & - & -- & ----- \\
\hline 1 & 6 & 0 & -2.428058 & -2.456413 & -.439943 \\
\hline 2 & 6 & 0 & -3.335544 & -1.427260 & -.158211 \\
\hline 3 & 6 & 0 & -2.873763 & -.125515 & .049658 \\
\hline 4 & 6 & 0 & -1.483439 & .126354 & -.024507 \\
\hline 5 & 6 & 0 & -.579180 & -.894124 & -.294561 \\
\hline 6 & 6 & 0 & -1.065417 & -2.194729 & -.509551 \\
\hline 7 & 8 & 0 & -3.657574 & .947661 & .323635 \\
\hline 8 & 6 & 0 & -5.065721 & .755571 & .408334 \\
\hline 9 & 8 & 0 & -1.109903 & 1.439257 & .192651 \\
\hline 10 & 6 & 0 & .167082 & 1.892607 & -.006218 \\
\hline 11 & 6 & 0 & 1.211134 & .891339 & -.353420 \\
\hline 12 & 6 & 0 & .905001 & -.600395 & -.362595 \\
\hline 13 & 8 & 0 & .372206 & 3.077921 & .125298 \\
\hline 14 & 6 & 0 & 2.447623 & 1.337071 & -.629574 \\
\hline 15 & 6 & 0 & 3.598602 & .420356 & -.935892 \\
\hline 16 & 6 & 0 & 4.019127 & -.453416 & .254711 \\
\hline 17 & 6 & 0 & 3.006911 & -1.271852 & .962699 \\
\hline 18 & 6 & 0 & 1.686197 & -1.347735 & .712463 \\
\hline 19 & 8 & 0 & 5.191367 & -.494386 & .600906 \\
\hline 20 & 1 & 0 & 1.259157 & -.989829 & -1.332635 \\
\hline 21 & 1 & 0 & -5.481221 & 1.737634 & .635133 \\
\hline 22 & 1 & 0 & -5.324933 & .054488 & 1.211217 \\
\hline 23 & 1 & 0 & -5.476791 & .395216 & -.542765 \\
\hline 24 & 1 & 0 & 3.425874 & -1.863149 & 1.773218 \\
\hline 25 & 1 & 0 & 4.482129 & .973159 & -1.257628 \\
\hline 26 & 1 & 0 & 3.317828 & -.268174 & -1.750519 \\
\hline 27 & 1 & 0 & 2.630032 & 2.407375 & -.599854 \\
\hline 28 & 1 & 0 & -4.395096 & -1.645595 & -.108062 \\
\hline 29 & 1 & 0 & -2.798814 & -3.462735 & -.607626 \\
\hline 30 & 1 & 0 & -.365599 & -2.994784 & -.734698 \\
\hline 31 & 1 & 0 & 1.095335 & -2.018382 & 1.333952 \\
\hline
\end{tabular}

\begin{tabular}{|c|c|c|c|c|}
\hline & & 1 & 2 & 3 \\
\hline & & A & A & A \\
\hline Frequencies & -- & 37.1078 & 61.5411 & 64.4137 \\
\hline Red. masses & -- & 5.8085 & 6.9639 & 4.5436 \\
\hline Frc consts & -- & .0047 & .0155 & .0111 \\
\hline IR Inten & -- & .4599 & 6.3032 & .4052 \\
\hline
\end{tabular}


Theoretical data for compound $\mathbf{1 4 b}$ :

Final Energy in Hartrees: HF $=-879.7203451(B 3 L Y P / 6-31++G(D, P))$

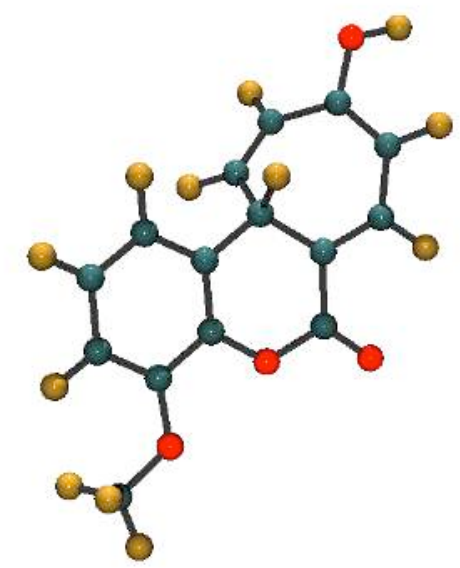

Standard orientation:

\begin{tabular}{|c|c|c|c|c|c|}
\hline \multirow{2}{*}{$\begin{array}{l}\text { Center } \\
\text { Number }\end{array}$} & \multirow{2}{*}{$\begin{array}{l}\text { Atomic } \\
\text { Number }\end{array}$} & \multirow{2}{*}{$\begin{array}{c}\text { Atomic } \\
\text { Type }\end{array}$} & \multicolumn{3}{|c|}{ Coordinates (Angstroms) } \\
\hline & & & $\mathrm{x}$ & Y & Z \\
\hline 1 & 6 & 0 & -2.302087 & -2.519815 & -.434298 \\
\hline 2 & 6 & 0 & -3.267516 & -1.530642 & -.205651 \\
\hline 3 & 6 & 0 & -2.876941 & -.204986 & -.000965 \\
\hline 4 & 6 & 0 & -1.498893 & .113357 & -.025110 \\
\hline 5 & 6 & 0 & -.538042 & -.867962 & -.244336 \\
\hline 6 & 6 & 0 & -.951528 & -2.193519 & -.455033 \\
\hline 7 & 8 & 0 & -3.724581 & .832651 & .224377 \\
\hline 8 & 6 & 0 & -5.122593 & .570978 & .249799 \\
\hline 9 & 8 & 0 & -1.193800 & 1.444316 & .183881 \\
\hline 10 & 6 & 0 & .075745 & 1.949155 & .028450 \\
\hline 11 & 6 & 0 & 1.168273 & .988245 & -.225547 \\
\hline 12 & 6 & 0 & .927832 & -.506104 & -.239028 \\
\hline 13 & 8 & 0 & .211671 & 3.151788 & .109336 \\
\hline 14 & 6 & 0 & 2.410888 & 1.485001 & -.488270 \\
\hline 15 & 6 & 0 & 3.618654 & .723579 & -.604243 \\
\hline 16 & 6 & 0 & 3.897724 & -.447497 & .062072 \\
\hline 17 & 6 & 0 & 3.021944 & -1.111704 & 1.005160 \\
\hline 18 & 6 & 0 & 1.673840 & -1.090359 & .943216 \\
\hline 19 & 8 & 0 & 5.142422 & -1.011227 & .019009 \\
\hline 20 & 1 & 0 & -2.618586 & -3.545216 & -.598372 \\
\hline 21 & 1 & 0 & -4.316721 & -1.799204 & -.193540 \\
\hline 22 & 1 & 0 & -.202908 & -2.960084 & -.634677 \\
\hline 23 & 1 & 0 & -5.597285 & 1.534260 & .438612 \\
\hline 24 & 1 & 0 & -5.383890 & -.128761 & 1.053513 \\
\hline 25 & 1 & 0 & -5.471973 & .173316 & -.711268 \\
\hline 26 & 1 & 0 & 1.396544 & -.906992 & -1.152292 \\
\hline 27 & 1 & 0 & 2.494262 & 2.562413 & -.608988 \\
\hline 28 & 1 & 0 & 4.443738 & 1.199189 & -1.134619 \\
\hline 29 & 1 & 0 & 3.521378 & -1.626693 & 1.821728 \\
\hline 30 & 1 & 0 & 1.091573 & -1.511459 & 1.759483 \\
\hline 31 & 1 & 0 & 5.734387 & -.477373 & -.529699 \\
\hline
\end{tabular}

\begin{tabular}{|c|c|c|c|c|}
\hline & & 1 & 2 & 3 \\
\hline & & A & A & A \\
\hline Frequencies & -- & 39.4168 & 64.6039 & 85.0857 \\
\hline Red. masses & -- & 4.9099 & 4.5417 & 4.3780 \\
\hline Frc consts & -- & .0045 & .0112 & .0187 \\
\hline IR Inten & -- & 1.8318 & 2.3416 & 1.1459 \\
\hline
\end{tabular}


Theoretical data for compound 14c :

Final Energy in Hartrees: HF $=-879.1933354(B 3 L Y P / 6-31++G(D, P))$

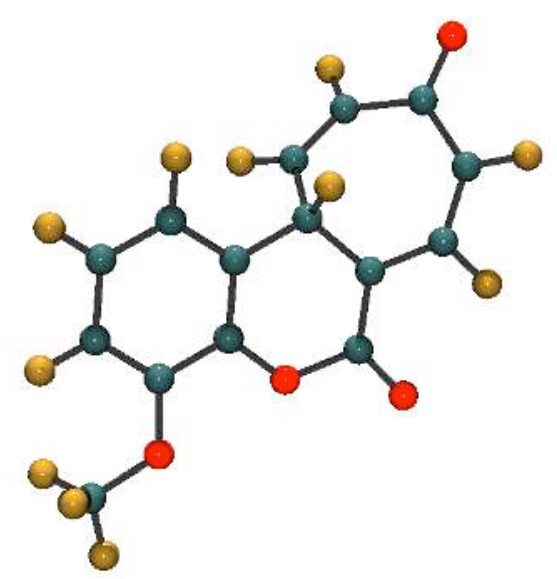

Standard orientation:

\begin{tabular}{|c|c|c|c|c|c|}
\hline \multirow{2}{*}{$\begin{array}{l}\text { Center } \\
\text { Number }\end{array}$} & \multirow{2}{*}{$\begin{array}{l}\text { Atomic } \\
\text { Number }\end{array}$} & \multirow{2}{*}{$\begin{array}{c}\text { Atomic } \\
\text { Type }\end{array}$} & \multicolumn{3}{|c|}{ Coordinates (Angstroms) } \\
\hline & & & $\mathrm{X}$ & Y & $\mathrm{Z}$ \\
\hline & & & & & --- \\
\hline 1 & 6 & 0 & -2.256912 & -2.517871 & -.424628 \\
\hline 2 & 6 & 0 & -3.229952 & -1.530435 & -.206917 \\
\hline 3 & 6 & 0 & -2.841695 & -.205508 & -.004271 \\
\hline 4 & 6 & 0 & -1.465666 & .136787 & -.016755 \\
\hline 5 & 6 & 0 & -.498777 & -.848630 & -.223588 \\
\hline 6 & 6 & 0 & -.910031 & -2.176345 & -.432213 \\
\hline 7 & 8 & 0 & -3.711672 & .831001 & .213157 \\
\hline 8 & 6 & 0 & -5.095874 & .546112 & .224565 \\
\hline 9 & 8 & 0 & -1.173144 & 1.451728 & .184275 \\
\hline 10 & 6 & 0 & .151900 & 1.958763 & .035699 \\
\hline 11 & 6 & 0 & 1.201216 & 1.012257 & -.166304 \\
\hline 12 & 6 & 0 & .967110 & -.482513 & -.219164 \\
\hline 13 & 8 & 0 & .224094 & 3.181355 & .097216 \\
\hline 14 & 6 & 0 & 2.491843 & 1.486971 & -.437165 \\
\hline 15 & 6 & 0 & 3.682689 & .767606 & -.539034 \\
\hline 16 & 6 & 0 & 4.022863 & -.516361 & .027532 \\
\hline 17 & 6 & 0 & 3.072434 & -1.184897 & .963098 \\
\hline 18 & 6 & 0 & 1.729359 & -1.165589 & .903116 \\
\hline 19 & 8 & 0 & 5.165646 & -1.023801 & -.107814 \\
\hline 20 & 1 & 0 & -2.564965 & -3.547179 & -.586924 \\
\hline 21 & 1 & 0 & -4.278877 & -1.803509 & -.201590 \\
\hline 22 & 1 & 0 & -.151311 & -2.936975 & -.597251 \\
\hline 23 & 1 & 0 & -5.594895 & 1.500216 & .406185 \\
\hline 24 & 1 & 0 & -5.360708 & -.159042 & 1.025354 \\
\hline 25 & 1 & 0 & -5.435418 & .137060 & -.737713 \\
\hline 26 & 1 & 0 & 1.413699 & -.846133 & -1.163969 \\
\hline 27 & 1 & 0 & 2.554611 & 2.558221 & -.625899 \\
\hline 28 & 1 & 0 & 4.542887 & 1.282882 & -.963156 \\
\hline 29 & 1 & 0 & 3.566209 & -1.737341 & 1.761090 \\
\hline 30 & 1 & 0 & 1.146338 & -1.652549 & 1.685374 \\
\hline
\end{tabular}

\begin{tabular}{|c|c|c|c|c|}
\hline & & 1 & 2 & 3 \\
\hline & & A & A & A \\
\hline Frequencies & -- & 39.7482 & 61.4077 & 76.6007 \\
\hline Red. masses & -- & 4.7705 & 4.6043 & 5.4395 \\
\hline Frc consts & -- & .0044 & .0102 & .0188 \\
\hline IR Inten & -- & .1498 & 1.2772 & 7.0362 \\
\hline
\end{tabular}




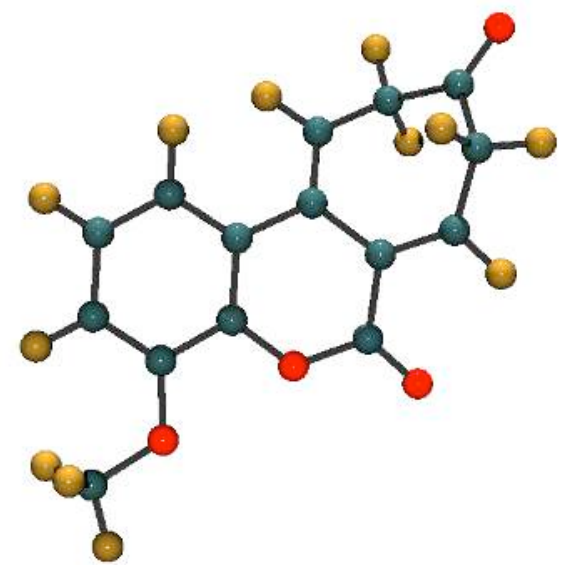

Standard orientation:

\begin{tabular}{|c|c|c|c|c|c|}
\hline \multirow{2}{*}{$\begin{array}{l}\text { Center } \\
\text { Number }\end{array}$} & \multirow{2}{*}{$\begin{array}{l}\text { Atomic } \\
\text { Number }\end{array}$} & \multirow{2}{*}{$\begin{array}{c}\text { Atomic } \\
\text { Type }\end{array}$} & \multicolumn{3}{|c|}{ Coordinates (Angstroms) } \\
\hline & & & $\mathrm{x}$ & $\mathrm{Y}$ & Z \\
\hline 1 & 6 & 0 & 2.311009 & -2.527939 & .324768 \\
\hline 2 & 6 & 0 & 3.281105 & -1.518780 & .251171 \\
\hline 3 & 6 & 0 & 2.895084 & -.192142 & .043963 \\
\hline 4 & 6 & 0 & 1.520691 & .101334 & -.091232 \\
\hline 5 & 6 & 0 & .549101 & -.902342 & -.036371 \\
\hline 6 & 6 & 0 & .962739 & -2.229983 & .185741 \\
\hline 7 & 8 & 0 & 3.742321 & .865232 & -.043142 \\
\hline 8 & 6 & 0 & 5.139882 & .625065 & .080462 \\
\hline 9 & 8 & 0 & 1.212119 & 1.429041 & -.322150 \\
\hline 10 & 6 & 0 & -.064550 & 1.918322 & -.213411 \\
\hline 11 & 6 & 0 & -1.136157 & .920373 & .065785 \\
\hline 12 & 6 & 0 & -.856974 & -.493196 & -.220746 \\
\hline 13 & 8 & 0 & -.236746 & 3.108099 & -.344168 \\
\hline 14 & 6 & 0 & -2.291527 & 1.372462 & .610468 \\
\hline 15 & 6 & 0 & -3.394678 & .498049 & 1.119018 \\
\hline 16 & 6 & 0 & -4.095316 & -.401148 & .087301 \\
\hline 17 & 6 & 0 & -3.213951 & -.895691 & -1.062952 \\
\hline 18 & 6 & 0 & -1.821990 & -1.321696 & -.693894 \\
\hline 19 & 8 & 0 & -5.264521 & -.696550 & .189425 \\
\hline 20 & 1 & 0 & 5.614512 & 1.600938 & -.024627 \\
\hline 21 & 1 & 0 & 5.500787 & -.044179 & -.710296 \\
\hline 22 & 1 & 0 & 5.386654 & .202343 & 1.062216 \\
\hline 23 & 1 & 0 & -4.161394 & 1.070634 & 1.643938 \\
\hline 24 & 1 & 0 & -2.971324 & -.224324 & 1.837361 \\
\hline 25 & 1 & 0 & -2.394614 & 2.446478 & .740402 \\
\hline 26 & 1 & 0 & -3.157621 & -.026904 & -1.741269 \\
\hline 27 & 1 & 0 & -3.753540 & -1.688865 & -1.583330 \\
\hline 28 & 1 & 0 & -1.567796 & -2.357364 & -.900217 \\
\hline 29 & 1 & 0 & 2.623756 & -3.552154 & .502580 \\
\hline 30 & 1 & 0 & .220555 & -3.016380 & .269789 \\
\hline 31 & 1 & 0 & 4.327838 & -1.772926 & .363310 \\
\hline
\end{tabular}

\begin{tabular}{lrrr} 
& \multicolumn{1}{c}{1} & \multicolumn{1}{c}{2} & \multicolumn{1}{c}{3} \\
& & \multicolumn{1}{c}{ A } & \multicolumn{1}{c}{ A } \\
Frequencies -- & 37.3845 & 49.5040 & 76.5492 \\
Red. masses -- & 6.7381 & 5.4742 & 4.4583 \\
Frc consts -- & .0055 & .0079 & .0154 \\
IR Inten -- & 1.3950 & 4.8171 & 1.1114
\end{tabular}


Theoretical data for compound $\mathbf{1 5 b}$ :

Final Energy in Hartrees: HF $=-879.7291446(B 3 L Y P / 6-31++G(D, P))$

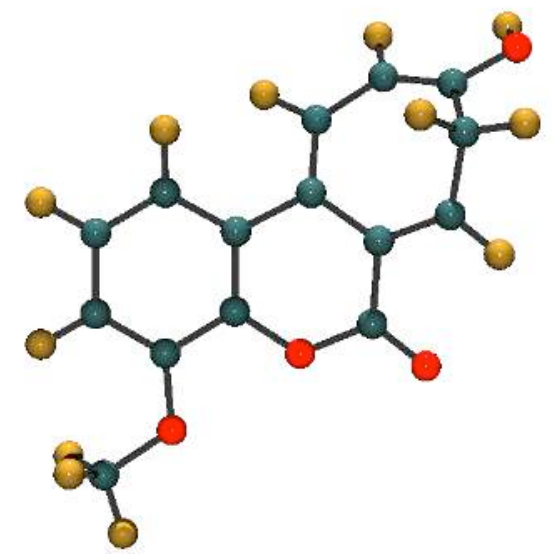

Standard orientation:

\begin{tabular}{|c|c|c|c|c|c|}
\hline \multirow{2}{*}{$\begin{array}{l}\text { Center } \\
\text { Number }\end{array}$} & \multirow{2}{*}{$\begin{array}{l}\text { Atomic } \\
\text { Number }\end{array}$} & \multirow{2}{*}{$\begin{array}{c}\text { Atomic } \\
\text { Type }\end{array}$} & \multicolumn{3}{|c|}{ Coordinates (Angstroms) } \\
\hline & & & $\mathrm{X}$ & Y & Z \\
\hline 1 & 6 & 0 & 2.452177 & -2.471743 & .301562 \\
\hline 2 & 6 & 0 & 3.376013 & -1.425507 & .170925 \\
\hline 3 & 6 & 0 & 2.922618 & -.116454 & -.009047 \\
\hline 4 & 6 & 0 & 1.532521 & .120608 & -.063124 \\
\hline 5 & 6 & 0 & .602907 & -.918013 & .049285 \\
\hline 6 & 6 & 0 & 1.087206 & -2.227568 & .247458 \\
\hline 7 & 8 & 0 & 3.719796 & .976315 & -.143208 \\
\hline 8 & 6 & 0 & 5.129619 & .793586 & -.096146 \\
\hline 9 & 8 & 0 & 1.156693 & 1.431383 & -.271378 \\
\hline 10 & 6 & 0 & -.139784 & 1.857279 & -.141651 \\
\hline 11 & 6 & 0 & -1.163184 & .823822 & .190349 \\
\hline 12 & 6 & 0 & -.827234 & -.576796 & -.033439 \\
\hline 13 & 8 & 0 & -.367624 & 3.036014 & -.296596 \\
\hline 14 & 6 & 0 & -2.368943 & 1.276494 & .624110 \\
\hline 15 & 6 & 0 & -3.428831 & .352932 & 1.150660 \\
\hline 16 & 6 & 0 & -3.937662 & -.412519 & -.036760 \\
\hline 17 & 6 & 0 & -3.155154 & -1.306813 & -.705647 \\
\hline 18 & 6 & 0 & -1.752794 & -1.496706 & -.482072 \\
\hline 19 & 8 & 0 & -5.238088 & -.159078 & -.343281 \\
\hline 20 & 1 & 0 & 5.558258 & 1.788282 & -.221923 \\
\hline 21 & 1 & 0 & 5.475320 & .141417 & -.907981 \\
\hline 22 & 1 & 0 & 5.446701 & .378378 & .868685 \\
\hline 23 & 1 & 0 & -3.624222 & -1.949613 & -1.449853 \\
\hline 24 & 1 & 0 & -4.247186 & .902722 & 1.618551 \\
\hline 25 & 1 & 0 & -3.001893 & -.346426 & 1.882264 \\
\hline 26 & 1 & 0 & -2.560444 & 2.345003 & .591755 \\
\hline 27 & 1 & 0 & -1.359379 & -2.453114 & -.817727 \\
\hline 28 & 1 & 0 & 2.814963 & -3.482589 & .460764 \\
\hline 29 & 1 & 0 & .385244 & -3.042283 & .387485 \\
\hline 30 & 1 & 0 & 4.437019 & -1.636710 & .220276 \\
\hline 31 & 1 & 0 & -5.467440 & -.557752 & -1.195382 \\
\hline
\end{tabular}

\begin{tabular}{|c|c|c|c|c|}
\hline & & 1 & 2 & 3 \\
\hline & & A & A & A \\
\hline Frequencies & -- & 40.5628 & 78.1995 & 86.3837 \\
\hline Red. masses & -- & 4.9080 & 4.5149 & 4.1037 \\
\hline Frc consts & -- & .0048 & .0163 & .0180 \\
\hline IR Inten & -- & 2.9038 & .5360 & 1.7504 \\
\hline
\end{tabular}


Theoretical data for compound $15 \mathrm{c}$ :

Final Energy in Hartrees: HF $=-879.2055479(B 3 L Y P / 6-31++G(D, P))$

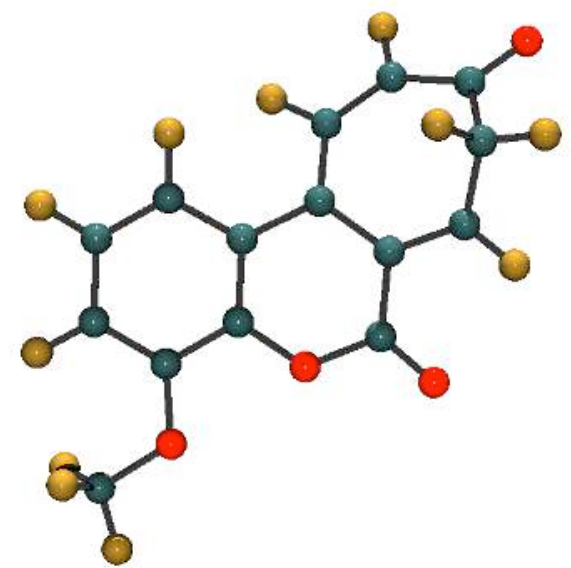

Standard orientation:

\begin{tabular}{|c|c|c|c|c|c|}
\hline \multirow{2}{*}{$\begin{array}{l}\text { Center } \\
\text { Number }\end{array}$} & \multirow{2}{*}{$\begin{array}{l}\text { Atomic } \\
\text { Number }\end{array}$} & \multirow{2}{*}{$\begin{array}{c}\text { Atomic } \\
\text { Type }\end{array}$} & \multicolumn{3}{|c|}{ Coordinates (Angstroms) } \\
\hline & & & $\mathrm{X}$ & Y & Z \\
\hline & & & -- & --- & -------- \\
\hline 1 & 6 & 0 & 2.390492 & -2.488787 & .253725 \\
\hline 2 & 6 & 0 & 3.337309 & -1.455913 & .166428 \\
\hline 3 & 6 & 0 & 2.888422 & -.138110 & .019958 \\
\hline 4 & 6 & 0 & 1.508911 & .123409 & -.047024 \\
\hline 5 & 6 & 0 & .544693 & -.899304 & .039652 \\
\hline 6 & 6 & 0 & 1.029889 & -2.222583 & .201784 \\
\hline 7 & 8 & 0 & 3.715588 & .953953 & -.081024 \\
\hline 8 & 6 & 0 & 5.111041 & .733664 & -.041981 \\
\hline 9 & 8 & 0 & 1.151601 & 1.439179 & -.248596 \\
\hline 10 & 6 & 0 & -.156242 & 1.877657 & -.168009 \\
\hline 11 & 6 & 0 & -1.192217 & .867665 & .138319 \\
\hline 12 & 6 & 0 & -.861061 & -.536695 & -.034373 \\
\hline 13 & 8 & 0 & -.336711 & 3.068720 & -.345286 \\
\hline 14 & 6 & 0 & -2.425266 & 1.333980 & .502878 \\
\hline 15 & 6 & 0 & -3.490545 & .449728 & 1.067919 \\
\hline 16 & 6 & 0 & -4.097018 & -.418521 & -.051232 \\
\hline 17 & 6 & 0 & -3.198306 & -1.358384 & -.659633 \\
\hline 18 & 6 & 0 & -1.821369 & -1.475951 & -.466997 \\
\hline 19 & 8 & 0 & -5.309909 & -.321441 & -.329933 \\
\hline 20 & 1 & 0 & 5.571413 & 1.718727 & -.145046 \\
\hline 21 & 1 & 0 & 5.445055 & .089451 & -.867620 \\
\hline 22 & 1 & 0 & 5.426867 & .284869 & .910499 \\
\hline 23 & 1 & 0 & -3.688222 & -2.134703 & -1.244825 \\
\hline 24 & 1 & 0 & -4.299193 & 1.032836 & 1.515533 \\
\hline 25 & 1 & 0 & -3.058480 & -.213151 & 1.834018 \\
\hline 26 & 1 & 0 & -2.622078 & 2.396647 & .398796 \\
\hline 27 & 1 & 0 & -1.400211 & -2.421288 & -.812415 \\
\hline 28 & 1 & 0 & 2.734202 & -3.512162 & .383788 \\
\hline 29 & 1 & 0 & .318616 & -3.033377 & .316397 \\
\hline 30 & 1 & 0 & 4.395101 & -1.682254 & .221121 \\
\hline
\end{tabular}

1

A

Frequencies -

Red. masses --

Frc consts --

IR Inten
39.8844

4.6962

.0044

.4875
2

A

77.0514

4.2661

.0149

3.6547
3

A

81.3043

4. 4123

.0172

.9263 
Theoretical data for compound $\mathbf{6 b}$ :

Final Energy in Hartrees: HF $=-879.7281245$ (B3LYP / 6-31++G(D,P))

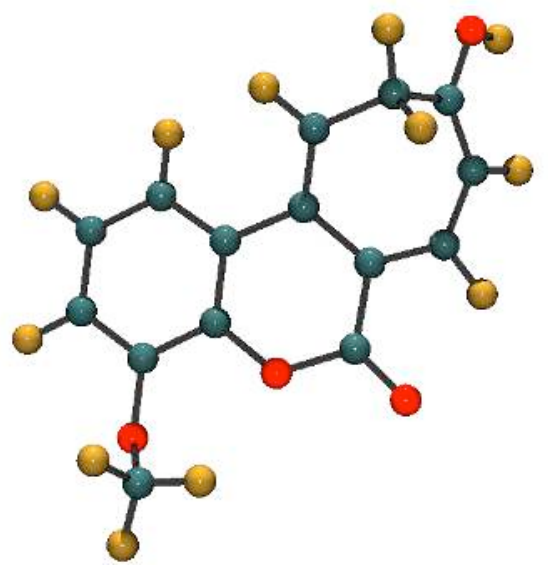

Standard orientation:

\begin{tabular}{|c|c|c|c|c|c|}
\hline \multirow{2}{*}{$\begin{array}{l}\text { Center } \\
\text { Number }\end{array}$} & \multirow{2}{*}{$\begin{array}{l}\text { Atomic } \\
\text { Number }\end{array}$} & \multirow{2}{*}{$\begin{array}{c}\text { Atomic } \\
\text { Type }\end{array}$} & \multicolumn{3}{|c|}{ Coordinates (Angstroms) } \\
\hline & & & $\mathrm{X}$ & Y & Z \\
\hline & - & & & -- & --- \\
\hline 1 & 6 & 0 & 2.156982 & -2.741821 & -.383779 \\
\hline 2 & 6 & 0 & 3.197051 & -1.808231 & -.431506 \\
\hline 3 & 6 & 0 & 2.930417 & -.449733 & -.267431 \\
\hline 4 & 6 & 0 & 1.599094 & -.038200 & -.059659 \\
\hline 5 & 6 & 0 & .548367 & -.962563 & .022299 \\
\hline 6 & 6 & 0 & .850160 & -2.325031 & -.154006 \\
\hline 7 & 8 & 0 & 3.961138 & .442011 & -.401720 \\
\hline 8 & 6 & 0 & 4.288813 & 1.247751 & .742391 \\
\hline 9 & 8 & 0 & 1.394338 & 1.320254 & .068330 \\
\hline 10 & 6 & 0 & .141566 & 1.890041 & -.000246 \\
\hline 11 & 6 & 0 & -1.017614 & .970414 & -.032739 \\
\hline 12 & 6 & 0 & -.813478 & -.442862 & .281663 \\
\hline 13 & 8 & 0 & .081709 & 3.100619 & -.016327 \\
\hline 14 & 6 & 0 & -2.187066 & 1.510666 & -.525386 \\
\hline 15 & 6 & 0 & -3.434384 & .852616 & -.747499 \\
\hline 16 & 6 & 0 & -3.867534 & -.219079 & -.020772 \\
\hline 17 & 6 & 0 & -3.143094 & -.687464 & 1.206783 \\
\hline 18 & 6 & 0 & -1.807881 & -1.230920 & .769667 \\
\hline 19 & 8 & 0 & -5.001748 & -.908645 & -.293609 \\
\hline 20 & 1 & 0 & 2.370731 & -3.796165 & -.529112 \\
\hline 21 & 1 & 0 & 4.223597 & -2.110031 & -.611112 \\
\hline 22 & 1 & 0 & .051522 & -3.058214 & -.132446 \\
\hline 23 & 1 & 0 & 5.180076 & 1.809913 & .459434 \\
\hline 24 & 1 & 0 & 4.517963 & .608531 & 1.604126 \\
\hline 25 & 1 & 0 & 3.479310 & 1.938216 & .989882 \\
\hline 26 & 1 & 0 & -2.113743 & 2.541348 & -.863889 \\
\hline 27 & 1 & 0 & -4.088692 & 1.269367 & -1.511733 \\
\hline 28 & 1 & 0 & -3.735047 & -1.453220 & 1.711339 \\
\hline 29 & 1 & 0 & -3.009920 & .160082 & 1.892764 \\
\hline 30 & 1 & 0 & -1.643788 & -2.296794 & .889977 \\
\hline 31 & 1 & 0 & -5.363877 & -.640438 & -1.151309 \\
\hline
\end{tabular}

\begin{tabular}{lrr} 
& & \multicolumn{1}{c}{1} \\
& & \multicolumn{1}{c}{ A } \\
Frequencies -- & 44.2913 \\
Red. masses -- & 5.6905 \\
Frc consts -- & .0066 \\
IR Inten & -- & 1.7936
\end{tabular}

2
A
59.7389
2.0570
.0043
3.8444

3

A

70.4787

3.4938

.0102

.9854 
Theoretical data for compound $6 \mathrm{c}$ :

Final Energy in Hartrees: HF $=-879.2136405(B 3 L Y P / 6-31++G(D, P))$

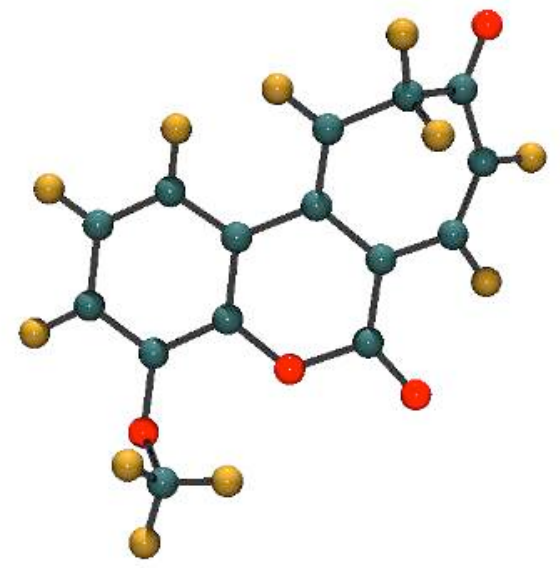

Standard orientation:

\begin{tabular}{|c|c|c|c|c|c|}
\hline \multirow{2}{*}{$\begin{array}{l}\text { Center } \\
\text { Number }\end{array}$} & \multirow{2}{*}{$\begin{array}{l}\text { Atomic } \\
\text { Number }\end{array}$} & \multirow{2}{*}{$\begin{array}{c}\text { Atomic } \\
\text { Type }\end{array}$} & \multicolumn{3}{|c|}{ Coordinates (Angstroms) } \\
\hline & & & $\mathrm{X}$ & Y & Z \\
\hline & & & & & -- \\
\hline 1 & 6 & 0 & 2.185309 & -2.715628 & -.451150 \\
\hline 2 & 6 & 0 & 3.217872 & -1.771403 & -.431789 \\
\hline 3 & 6 & 0 & 2.923821 & -.423348 & -.232175 \\
\hline 4 & 6 & 0 & 1.583825 & -.021499 & -.051986 \\
\hline 5 & 6 & 0 & .540493 & -.964032 & -.025046 \\
\hline 6 & 6 & 0 & .868203 & -2.315249 & -.244550 \\
\hline 7 & 8 & 0 & 3.964942 & .479378 & -.298058 \\
\hline 8 & 6 & 0 & 4.182045 & 1.301041 & .854313 \\
\hline 9 & 8 & 0 & 1.353882 & 1.316620 & .103115 \\
\hline 10 & 6 & 0 & .054628 & 1.868787 & -.057101 \\
\hline 11 & 6 & 0 & -1.051207 & .949796 & -.049098 \\
\hline 12 & 6 & 0 & -.829713 & -.466556 & .231270 \\
\hline 13 & 8 & 0 & .038906 & 3.088231 & -.168476 \\
\hline 14 & 6 & 0 & -2.285405 & 1.469457 & -.524359 \\
\hline 15 & 6 & 0 & -3.525127 & .871852 & -.677860 \\
\hline 16 & 6 & 0 & -4.016501 & -.305670 & -.006674 \\
\hline 17 & 6 & 0 & -3.154680 & -.817968 & 1.157600 \\
\hline 18 & 6 & 0 & -1.813531 & -1.295886 & .678651 \\
\hline 19 & 8 & 0 & -5.105635 & -.851162 & -.266622 \\
\hline 20 & 1 & 0 & 2.412757 & -3.763479 & -.628204 \\
\hline 21 & 1 & 0 & 4.254602 & -2.054259 & -.586565 \\
\hline 22 & 1 & 0 & .074104 & -3.053745 & -.268230 \\
\hline 23 & 1 & 0 & 5.095695 & 1.864704 & .649285 \\
\hline 24 & 1 & 0 & 4.333271 & .677344 & 1.746501 \\
\hline 25 & 1 & 0 & 3.348777 & 1.988128 & 1.018177 \\
\hline 26 & 1 & 0 & -2.197677 & 2.485931 & -.906055 \\
\hline 27 & 1 & 0 & -4.268355 & 1.394281 & -1.277253 \\
\hline 28 & 1 & 0 & -3.705123 & -1.625502 & 1.647432 \\
\hline 29 & 1 & 0 & -3.021895 & .003113 & 1.879168 \\
\hline 30 & 1 & 0 & -1.623113 & -2.363224 & .745801 \\
\hline
\end{tabular}

\begin{tabular}{|c|c|c|c|c|}
\hline & & 1 & 2 & 3 \\
\hline & & A & A & A \\
\hline Frequencies & -- & 45.9306 & 64.3066 & 76.7101 \\
\hline Red. masses & -- & 6.0821 & 4.1244 & 2.0953 \\
\hline Frc consts & -- & .0076 & .0100 & .0073 \\
\hline IR Inten & -- & .1810 & .4962 & 4.3992 \\
\hline
\end{tabular}


Theoretical data for compound $16 \mathrm{~b}$ :

Final Energy in Hartrees: HF $=-879.7239323(B 3 L Y P / 6-31++G(D, P))$

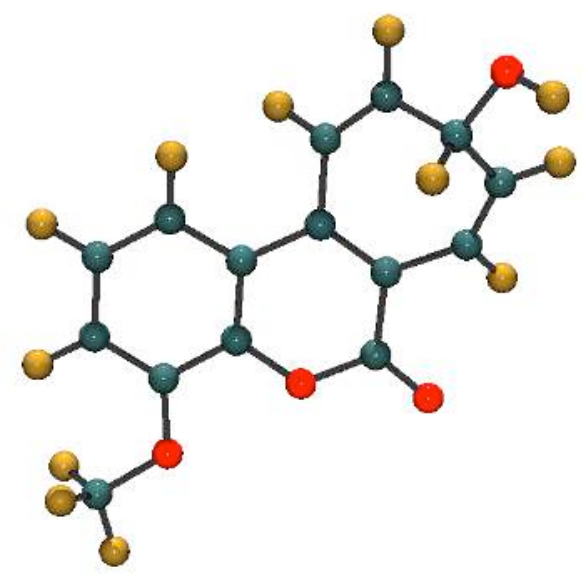

Standard orientation:

\begin{tabular}{|c|c|c|c|c|c|}
\hline \multirow{2}{*}{$\begin{array}{l}\text { Center } \\
\text { Number }\end{array}$} & \multirow{2}{*}{$\begin{array}{l}\text { Atomic } \\
\text { Number }\end{array}$} & \multirow{2}{*}{$\begin{array}{l}\text { Atomic } \\
\text { Type }\end{array}$} & \multicolumn{3}{|c|}{ Coordinates (Angstroms) } \\
\hline & & & $\mathrm{X}$ & $\mathrm{Y}$ & Z \\
\hline & 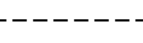 & & & -- & ------- \\
\hline 1 & 6 & 0 & 2.313636 & -2.524717 & -.034579 \\
\hline 2 & 6 & 0 & 3.287402 & -1.521575 & .099172 \\
\hline 3 & 6 & 0 & 2.910343 & -.179384 & .103795 \\
\hline 4 & 6 & 0 & 1.540311 & .140186 & -.039847 \\
\hline 5 & 6 & 0 & .562022 & -.850188 & -.191302 \\
\hline 6 & 6 & 0 & .973919 & -2.203104 & -.173513 \\
\hline 7 & 8 & 0 & 3.754516 & .875101 & .236832 \\
\hline 8 & 6 & 0 & 5.145914 & .612520 & .383549 \\
\hline 9 & 8 & 0 & 1.228656 & 1.467777 & -.018631 \\
\hline 10 & 6 & 0 & -.066495 & 1.926123 & -.115389 \\
\hline 11 & 6 & 0 & -1.143896 & .922561 & -.248391 \\
\hline 12 & 6 & 0 & -.835171 & -.431947 & -.327156 \\
\hline 13 & 8 & 0 & -.237690 & 3.126823 & -.095946 \\
\hline 14 & 6 & 0 & -2.461224 & 1.502454 & -.452011 \\
\hline 15 & 6 & 0 & -3.636450 & .915388 & -.146100 \\
\hline 16 & 6 & 0 & -3.710013 & -.397449 & .595603 \\
\hline 17 & 6 & 0 & -3.132057 & -1.428045 & -.328228 \\
\hline 18 & 6 & 0 & -1.828763 & -1.442453 & -.672601 \\
\hline 19 & 8 & 0 & -5.042575 & -.786329 & .918070 \\
\hline 20 & 1 & 0 & -5.402617 & -.160838 & 1.560309 \\
\hline 21 & 1 & 0 & -3.095492 & -.338933 & 1.508982 \\
\hline 22 & 1 & 0 & 5.620201 & 1.590181 & .471624 \\
\hline 23 & 1 & 0 & 5.547183 & .088860 & -.492954 \\
\hline 24 & 1 & 0 & 5.347403 & .025226 & 1.287983 \\
\hline 25 & 1 & 0 & 4.328959 & -1.798242 & .207039 \\
\hline 26 & 1 & 0 & 2.621108 & -3.565625 & -.020080 \\
\hline 27 & 1 & 0 & .236486 & -2.993098 & -.246137 \\
\hline 28 & 1 & 0 & -1.478040 & -2.262664 & -1.292258 \\
\hline 29 & 1 & 0 & -2.464268 & 2.502364 & -.875807 \\
\hline 30 & 1 & 0 & -3.821710 & -2.173319 & -.717202 \\
\hline 31 & 1 & 0 & -4.579352 & 1.376884 & -.432097 \\
\hline
\end{tabular}

\begin{tabular}{|c|c|c|c|c|}
\hline & & 1 & 2 & 3 \\
\hline & & A & $\mathrm{A}$ & A \\
\hline Frequencies & -- & 38.5875 & 70.4761 & 86.3899 \\
\hline Red. masses & -- & 5.0287 & 4.4451 & 4.4096 \\
\hline Frc consts & -- & .0044 & .0130 & .0194 \\
\hline IR Inten & -- & 1.2567 & 1.2303 & 7.4491 \\
\hline
\end{tabular}


Theoretical data for compound $16 \mathrm{c}$ :

Final Energy in Hartrees: HF $=-879.1417281(B 3 L Y P / 6-31++G(D, P))$

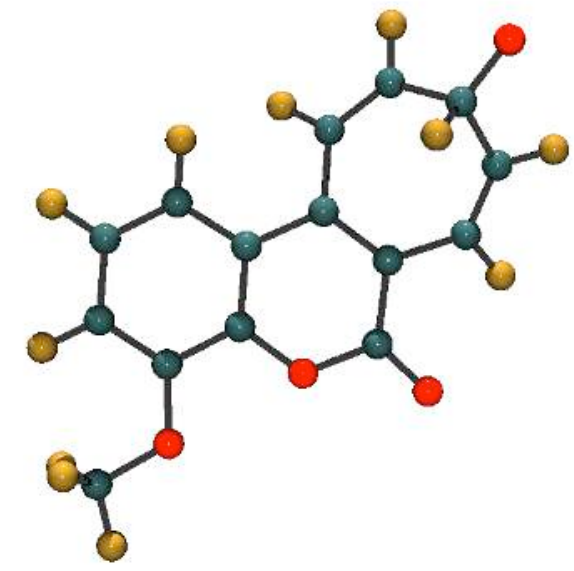

Standard orientation:

\begin{tabular}{|c|c|c|c|c|c|}
\hline \multirow{2}{*}{$\begin{array}{l}\text { Center } \\
\text { Number }\end{array}$} & \multirow{2}{*}{$\begin{array}{l}\text { Atomic } \\
\text { Number }\end{array}$} & \multirow{2}{*}{$\begin{array}{l}\text { Atomic } \\
\text { Type }\end{array}$} & \multicolumn{3}{|c|}{ Coordinates (Angstroms) } \\
\hline & & & $\mathrm{X}$ & $\mathrm{Y}$ & Z \\
\hline & & & -- & ---------- & -------- \\
\hline 1 & 6 & 0 & 2.281582 & -2.524999 & -.035969 \\
\hline 2 & 6 & 0 & 3.261516 & -1.525346 & .089227 \\
\hline 3 & 6 & 0 & 2.878583 & -.184698 & .093915 \\
\hline 4 & 6 & 0 & 1.511165 & .142633 & -.042844 \\
\hline 5 & 6 & 0 & .525904 & -.843638 & -.185644 \\
\hline 6 & 6 & 0 & .942042 & -2.196024 & -.165001 \\
\hline 7 & 8 & 0 & 3.737053 & .873108 & .221239 \\
\hline 8 & 6 & 0 & 5.116740 & .594821 & .373757 \\
\hline 9 & 8 & 0 & 1.202955 & 1.469012 & -.024553 \\
\hline 10 & 6 & 0 & -.107562 & 1.928751 & -.112176 \\
\hline 11 & 6 & 0 & -1.184774 & .933225 & -.210600 \\
\hline 12 & 6 & 0 & -.874951 & -.430643 & -.306307 \\
\hline 13 & 8 & 0 & -.243814 & 3.138224 & -.114622 \\
\hline 14 & 6 & 0 & -2.506742 & 1.491459 & -.388863 \\
\hline 15 & 6 & 0 & -3.682335 & .871297 & -.103912 \\
\hline 16 & 6 & 0 & -3.860251 & -.452074 & .665997 \\
\hline 17 & 6 & 0 & -3.185835 & -1.396347 & -.342675 \\
\hline 18 & 6 & 0 & -1.864998 & -1.423881 & -.663443 \\
\hline 19 & 8 & 0 & -5.115891 & -.766033 & .983134 \\
\hline 20 & 1 & 0 & -3.142960 & -.385738 & 1.533909 \\
\hline 21 & 1 & 0 & 5.607119 & 1.565853 & .463721 \\
\hline 22 & 1 & 0 & 5.521859 & .063080 & -.498288 \\
\hline 23 & 1 & 0 & 5.312953 & .003492 & 1.278647 \\
\hline 24 & 1 & 0 & 4.303681 & -1.803029 & .192161 \\
\hline 25 & 1 & 0 & 2.583543 & -3.568496 & -.018447 \\
\hline 26 & 1 & 0 & .195891 & -2.979095 & -.225125 \\
\hline 27 & 1 & 0 & -1.504932 & -2.244669 & -1.282131 \\
\hline 28 & 1 & 0 & -2.523449 & 2.508271 & -.774003 \\
\hline 29 & 1 & 0 & -3.870579 & -2.116700 & -.792319 \\
\hline 30 & 1 & 0 & -4.626040 & 1.335332 & -.392471 \\
\hline
\end{tabular}

\begin{tabular}{lrrr} 
& \multicolumn{1}{c}{1} & \multicolumn{1}{c}{2} & \multicolumn{1}{c}{3} \\
& & \multicolumn{1}{c}{ A } & \multicolumn{1}{c}{ A } \\
Frequencies -- & 37.4928 & 67.5092 & 80.6873 \\
Red. masses -- & 5.1564 & 4.8778 & 4.1550 \\
Frc consts -- & .0043 & .0131 & .0159 \\
IR Inten -- & 1.7583 & 3.0955 & 9.7902
\end{tabular}


Theoretical data for compound 17a :

Final Energy in Hartrees: HF $=-879.7122644(B 3 L Y P / 6-31++G(D, P))$

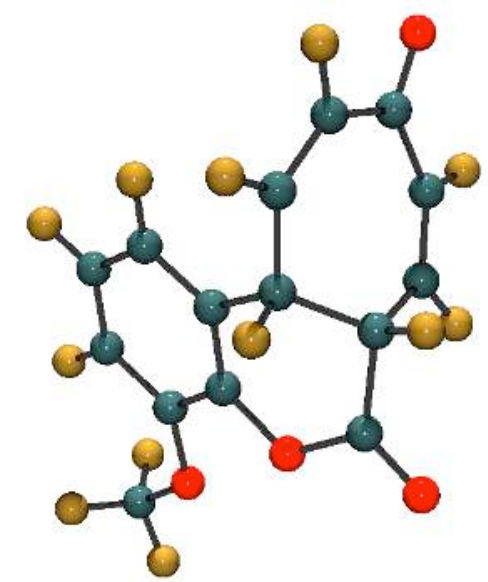

Standard orientation:

\begin{tabular}{|c|c|c|c|c|c|}
\hline \multirow{2}{*}{$\begin{array}{l}\text { Center } \\
\text { Number }\end{array}$} & \multirow{2}{*}{$\begin{array}{l}\text { Atomic } \\
\text { Number }\end{array}$} & \multirow{2}{*}{$\begin{array}{c}\text { Atomic } \\
\text { Type }\end{array}$} & \multicolumn{3}{|c|}{ Coordinates (Angstroms) } \\
\hline & & & $\mathrm{X}$ & Y & Z \\
\hline & & & & -- & ------ \\
\hline 1 & 6 & 0 & -1.407365 & -2.617793 & -.353510 \\
\hline 2 & 6 & 0 & -2.511180 & -1.883921 & .091888 \\
\hline 3 & 6 & 0 & -2.462644 & -.484794 & .108218 \\
\hline 4 & 6 & 0 & -1.287271 & .148718 & -.338407 \\
\hline 5 & 6 & 0 & -.185980 & -.577743 & -.788277 \\
\hline 6 & 6 & 0 & -.249333 & -1.976054 & -.787739 \\
\hline 7 & 8 & 0 & -3.465389 & .330273 & .524896 \\
\hline 8 & 6 & 0 & -4.678081 & -.263920 & .977631 \\
\hline 9 & 8 & 0 & -1.299485 & 1.539981 & -.344698 \\
\hline 10 & 6 & 0 & -.139932 & 2.263966 & -.352519 \\
\hline 11 & 6 & 0 & 1.164359 & 1.466933 & -.334175 \\
\hline 12 & 6 & 0 & 1.005148 & .244309 & -1.265935 \\
\hline 13 & 8 & 0 & -.200152 & 3.467952 & -.361076 \\
\hline 14 & 6 & 0 & 1.539576 & 1.167927 & 1.104427 \\
\hline 15 & 6 & 0 & 2.433881 & .279614 & 1.565513 \\
\hline 16 & 6 & 0 & 3.336691 & -.627133 & .816218 \\
\hline 17 & 6 & 0 & 3.248774 & -.862338 & -.648456 \\
\hline 18 & 6 & 0 & 2.270067 & -.540443 & -1.509397 \\
\hline 19 & 8 & 0 & 4.215835 & -1.221420 & 1.442351 \\
\hline 20 & 1 & 0 & .722069 & .661193 & -2.245052 \\
\hline 21 & 1 & 0 & 1.916690 & 2.147923 & -.750374 \\
\hline 22 & 1 & 0 & -5.326816 & .568478 & 1.251051 \\
\hline 23 & 1 & 0 & -4.507617 & -.898531 & 1.855855 \\
\hline 24 & 1 & 0 & -5.153477 & -.852466 & .183552 \\
\hline 25 & 1 & 0 & 4.088711 & -1.448926 & -1.012734 \\
\hline 26 & 1 & 0 & 2.607253 & .229950 & 2.637474 \\
\hline 27 & 1 & 0 & -3.399649 & -2.403535 & .429164 \\
\hline 28 & 1 & 0 & 2.386401 & -.900909 & -2.530410 \\
\hline 29 & 1 & 0 & -1.456377 & -3.702220 & -.353650 \\
\hline 30 & 1 & 0 & .606695 & -2.554914 & -1.116441 \\
\hline 31 & 1 & 0 & 1.049379 & 1.795701 & 1.846893 \\
\hline
\end{tabular}

\begin{tabular}{lrr} 
& & \multicolumn{1}{c}{1} \\
& & \multicolumn{1}{c}{ A } \\
Frequencies -- & 25.4191 \\
Red. masses -- & 8.2299 \\
Frc consts -- & .0031 \\
IR Inten -- & 4.0869
\end{tabular}

$\begin{array}{cr}2 & 3 \\ A & A \\ 48.0998 & 70.2939 \\ 4.7776 & 4.2892 \\ .0065 & .0125 \\ 1.8111 & 2.6267\end{array}$

